2015

\title{
The Process of Marriage Equality
}

Josh Blackman

South Texas College of Law

Howard M. Wasserman

Florida International University College of Law

Follow this and additional works at: https://ecollections.law.fiu.edu/faculty_publications

Part of the Jurisdiction Commons, Litigation Commons, and the Supreme Court of the United States Commons

\section{Recommended Citation}

Josh Blackman and Howard M. Wasserman, The Process of Marriage Equality, 43 Hastings Const. L.Q. 243 (2015).

Available at: https://ecollections.law.fiu.edu/faculty_publications/202 


\title{
The Process of Marriage Equality
}

\author{
by JOSH BLACKMAN* \& HOWARD M. WASSERMAN*
}

\section{Introduction}

The two-year race from United States $v$. Windsor ${ }^{1}$ to Obergefell $v$. Hodges $^{2}$ produced $^{3}$ an inconceivable sea change in substantive constitutional law. But just as important as the right to marry was the process through which that right was vindicated. Marriage equality was established via parallel litigation in thirty-seven states covering eight federal circuits. And that litigation triggered a complex twoyear interaction of the doctrine governing injunctions, precedent, stays, concurrent state-federal litigation, and abstention.

Many books and articles have and will be written about the marriage equality movement's rapid success. ${ }^{4}$ This is not one of those. Instead, as the title suggests, this article tells the story of the process of marriage equality and how four aspects of federal procedure and jurisdiction doctrine both enabled and frustrated marriage equality's advance to the Supreme Court.

* Associate Professor, South Texas College of Law, Houston.

* Professor of Law, FIU College of Law. The authors thank William Baude, Joshua Block, Brooke Coleman, Amanda Frost, Douglas Laycock, David Marcus, James Pfander, Richard Re, Martin Redish, and Kevin Walsh for comments and suggestions.

1. United States v. Windsor, 133 S. Ct. 2675 (2013).

2. Obergefell v. Hodges, 135 S. Ct. 2584 (2015).

3. Coincidentally or otherwise, Obergefell was decided on June 26, 2015, two years to the day after the Court issued Windsor and twelve years to the day of Lawrence $v$. Texas-all decisions authored by Justice Kennedy. During arguments in Obergefell, Kennedy pointed out that the twelve-year period since Lawrence in 2003 was roughly comparable to the thirteen years that elapsed between Brown and Loving v. Virginia. See argument in Obergefell v. Hodges, No. 14-556, at 6-7 (question from Justice Kennedy), http://www.supremecourt.gov/oral_arguments/argument_transcripts/14-556q1_6k47.pdf.

4. See, e.g., Michael J. Klarman, From the Closet to the Altar: Courts, BACKLASH, AND THE STRUGGLE FOR SAME-SEX MARRIAGE (2014); KENJI YOSHINO: SPEAK Now: MARRIAGE EQUALITY ON TRIAL (2015); Michael J. Perry, Obergefell v. Hodges: An Imagined Opinion, Concurring in the Judgment, http://ssrn.com/abstract =2624022; Louis Michael Seidman, The Triumph of Gay Marriage and the Failure of Constitutional Law, SUP. CT. REV. (forthcoming 2016). 
The first procedural issue relates to the scope of the injunctions barring enforcement of the state marriage bans. Courts, parties, and the public struggled to understand and define who was obligated to abide by any injunction and who was guaranteed a marriage license or recognition of a marriage under it. The answer involves a complex interaction among the concepts of judgments, injunctions, precedent, and departmentalism in constitutional interpretation. A court's judgment and injunction compel conduct by the named defendants as to the named plaintiffs - in other words, only the named defendant officials had to issue marriage licenses to the named plaintiff couples. ${ }^{5}$ As to everyone else, the judgment functions merely as precedentpersuasive when from the district court, binding regionally when from the court of appeals, and binding nationally when from the Supreme Court. $^{6}$ And precedent, whether binding or persuasive, does not directly control real-world conduct. It instead must be put into effect by a court issuing a new judgment and injunction compelling new named defendants to issue licenses to new named couples.

What we actually saw during the marriage equality litigation was widespread voluntary compliance by nonparty officials as to nonparty couples-once an injunction compelled marriage licenses as to some same-sex couples, officials began issuing licenses to other similarly situated couples-even though they were not required to do so by a court order. As a result, most courts never had to grapple with the proper scope of the injunction, the meaningful differences between judgment and precedent, the different effects of persuasive or binding precedent, or the limits on attempts to enforce injunctions. One exception, which one of us previously explored, was Alabama, where many officials refused to voluntarily comply with persuasive district court precedent. ${ }^{7}$ That refusal, which was procedurally proper, prompted unfortunate and inaccurate comparisons to George Wallace and massive resistance to Brown and desegregation. Problems over the scope of injunctions continued following Obergefell, as parties and courts struggled to understand the effect of

5. Douglas LAyCOCK, MODERN AMERICAN Remedies 217 (Concise 4th ed. 2012); see also David W. Marcus, The Public Interest Class Action, 104 GEO. L.J. (forthcoming 2015) (manuscript at 27-28), http://papers.ssrn.com/sol3/papers.cfm? abstract_id $=2565988$.

6. Richard H. Fallon, Jr., As Applied and Facial Challenges and Third-Party Standing, 113 HARV. L. REV. 1321, 1339-40 (2000); Richard H. Fallon, Jr., Fact and Fiction About Facial Challenges, 99 CALIF. L. REV. 915, 924 n.31 (2011).

7. Howard M. Wasserman, Crazy in Alabama: Judicial Process and the Last Stand Against Marriage Equality in the Land of George Wallace, 110 Nw. L. REV. ONLINE 1 (2015), http://www.northwesternlawreview.org/online/crazy-in-alabama. 
the Court's decision, how to implement it, how it affected pending litigation, and how it applied to new state officials. These struggles culminated in the infamous events in Rowan County, Kentucky, where a county clerk was held in contempt and jailed for failing to obey a district court injunction compelling issuance of marriage licenses to same-sex couples.

The second procedural issue involves the pivotal but underappreciated role of stays pending appeal. Following Windsor, federal district courts in more than two dozen states enjoined enforcement of bans on same-sex marriage. Judges then had to decide whether to stay those injunctions pending review. An injunction alters the status quo. A stay of an injunction suspends that alteration, ${ }^{9}$ while refusing to grant a stay allows that altered status quo to take immediate, and perhaps irreparable, effect. Here, the altered status quo meant issuance of hundreds or thousands of marriage licenses. In several cases, denial of stays triggered simultaneous races to the courts of appeals and to the altars, with couples trying to obtain marriage licenses before a higher court intervened. Many local licensing officials promptly (and eagerly) issued licenses, without waiting for an Article III-final judgment. State attorneys general frantically-and sometimes prematurelysought emergency stays from the courts of appeals and the Supreme Court.

Exacerbating these scrambles were shifting signals from the Supreme Court through unexplained stays, denials of stays, and denials of certiorari. William Baude identifies these orders as part of the Court's "shadow docket." Litigants and lower courts in the marriage equality cases struggled to understand and respond to those signals. The Court seemingly changed its stance in ways affecting the propriety of stays four times. First, in early 2014 the Justices intervened to stay two judgments from the District of Utah, signaling that injunctions should be stayed pending review. Some lower courts followed this signal, others distinguished it, and others simply ignored it. Second, in October 2014, the Court denied petitions for certiorari from five states in three circuits, establishing Article III-final judgments invalidating their marriage bans. From that point forward, most district courts ceased staying injunctions, as did the Supreme

8. See infra notes 128-34 and accompanying text.

9. Nken v. Holder, 129 S. Ct. 1749, 1758 (2009).

10. William Baude, Foreword: The Supreme Court's Shadow Docket, 9 N.Y.U. J. OF LAW \& LIBERTY. 1, 3, 5 (2015). 
Court, often over the dissent of Justices Scalia and Thomas. The final period began in January 2015, when the Court granted certiorari on the petition from the Sixth Circuit case that became Obergefell. District courts differed over the significance of the grant and how to resolve their pending cases with a final Supreme Court decision looming.

The third procedural issue concerned attempts by state attorneys general to move marriage cases out of federal court. In three states, officials initiated mandamus proceedings in the state Supreme Court for the express purpose of prohibiting local officials from issuing marriage licenses based solely on voluntary compliance with federal precedent. ${ }^{11}$ State officials then argued to the federal courts that the pending mandamus actions stripped their jurisdiction or required abstention in deference to the pending state actions they had initiated. Acting correctly, federal courts forcefully rejected these arguments. ${ }^{12}$

Scholars will spend many years and pages exploring the rapid establishment of the constitutional right to marriage equality. This paper contributes to that conversation by focusing, for the first time, on the critical, but underdeveloped, procedural nuances of highstakes constitutional and civil rights litigation. We offer both a detailed historical record of the litigation that produced this constitutional watershed, as well as a better understanding of how procedure, jurisdiction, and the judicial process affect future constitutional litigation. The results in the marriage litigation were decidedly mixed. Courts and litigants often got procedure very wrong in a way that confused, extended, and raised the cost of litigation and that contributed to widespread public misunderstanding of these issues.

We proceed in three parts. Part I clarifies the proper scope of injunctions, highlights the confusion between judgments and precedent, and explores how that confusion affected the marriage equality litigation. Part II assesses how lower courts handled stays pending review, particularly in light of the signals from the Supreme Court's grants and denials of stays and grants and denials of certiorari. Part III analyzes state efforts to preempt federal litigation

11. Ex parte State ex rel. Ala. Policy Inst., No. 1140460, 2015 WL 892752, at *43 (Ala. Mar. 3, 2015), abrogated by Obergefell v. Hodges, 135 S. Ct. 1039 (2015); State ex rel. Schmidt v. Moriarty, No. 112, 590 (Kan. Oct. 10, 2014); State ex rel. Wilson v. Condon, 764 S.E. $2 d 247$ (S.C. 2014).

12. Marie v. Moser, 65 F. Supp. 3d 1175, 1185 (D. Kan. 2014); Condon v. Haley, 21 F. Supp. 3d 572 (D.S.C. 2014). 
through parallel state litigation, and how they offered unsuccessful arguments about jurisdiction and abstention.

\section{Framing the Litigation and Framing the Injunction}

On June 27, 2013, (the day after Windsor), marriage equality had been established by legislation, popular enactment, or state court judgment in thirteen states. What followed in the next two years was a massive campaign of parallel constitutional litigation challenging virtually identical same-sex marriage bans in thirty-seven states and two territories, covering nine federal circuits.

Challenges to marriage bans typically were brought by one or a small number of same-sex couples who could not obtain marriage licenses or have out-of-state marriages recognized because of the challenged state laws. ${ }^{13}$ The defendants were state, county, and local officials responsible for issuing licenses or otherwise enforcing that state's same-sex marriage ban.

The challenges were largely identical because the bans in every state were substantially identical in substance, if not in language. Every state defined marriage as being between one man and one woman and prohibited any other combination to be married, recognized as married, or entitled to receive the benefits, protections, and incidents of marriage. The challenged state action also was the

13. For example, Obergefell involved fourteen same-sex couples and two men seeking marital status for their deceased same-sex partners, spread over four states. Obergefell v. Hodges, 135 S. Ct. 2584 (2015). More specifically, the Michigan case was brought by one lesbian couple; the Kentucky case was two couples seeking Kentucky marriage licenses and four couples seeking recognition of their out-of-state marriages; the Ohio case involved four couples seeking recognition of out-of-state marriages for purposes of their children's birth certificates and two men seeking recognition of their marital status on their same-sex partners' death certificates; and the Tennessee case involved three couples seeking recognition of out-of-state marriages. DeBoer v. Snyder, 772 F.3d 388, 396-99 (6th Cir. 2014).

Although never raised, there is at least a nice question whether plaintiffs properly could sue together in this way. Parties may join as plaintiffs if their claims arise out of the same transaction, occurrence, or series of transactions or occurrences and if the claims raise common questions of law or fact. FED. R. CIV. P. 20(a)(1)(A), (B). The second prong is easily satisfied, as the legal question of the validity of the marriage bans is common to all claims. But the first prong is far less clear, because there is no logical relationship among the different plaintiffs' claims - there is no connection among the couples or their desire to marry, other than their wanting to engage in parallel conduct of getting married. The counter is that the defendant officials applied the same law-the state ban on same-sex marriage-in denying each plaintiff a marriage license. In any event, no one raised the issue because even had the plaintiffs filed separately, the common questions of law or fact allowed the cases to be consolidated and for certain issues, such as preliminary injunctions, to be resolved together. FED. R. CIV. P. 42(a). 
same in every state - the refusal by a state official to issue a marriage license or to recognize an out-of-state marriage for two people who, but for being of the same sex, were entitled to receive marriage licenses or have their marriages recognized in that state. Unique among constitutional litigation challenging state laws, there was no possibility of legal, factual, remedial, or administrative differences among different cases or plaintiffs. ${ }^{14}$ With so many states having identical prohibitions on same-sex marriage, it functionally established a nationwide prohibition on same-sex marriage, but one that had to be challenged state by state.

In many cases, having declared the state marriage ban unconstitutional, district courts entered exceedingly broad injunctions. Several injunctions purported to both prohibit defendant officials from ever enforcing same-sex marriage bans anywhere in the state as to any couple or any person, and to require them to grant marriage licenses to any couple requesting one statewide, even where only one couple brought the action. ${ }^{15}$

Consider Judge Vaughn Walker's order from the Proposition 8 case in California that started it all:

[T]he court orders entry of judgment permanently enjoining [Proposition 8's] enforcement; prohibiting the official defendants from applying or enforcing Proposition 8 and directing the official defendants that all persons under their control or supervision shall not apply or enforce Proposition $8 .^{16}$

Or the order from Chief Magistrate Judge Candy Wagahoof Dale in the District of Idaho:

The Court PERMANENTLY ENJOINS the State of Idaho and its officers, employees, agents, and political subdivisions from enforcing Article III, $\S 28$ of the Idaho Constitution; Idaho Code Sections 32-201 and 32-209; and any other laws or regulations to the extent they do not recognize same-sex marriages validly

14. Maureen Carroll, Class Action Myopia, 65 DUKE L.J. (forthcoming 2016), http://papers.ssrn.com/sol3/papers.cfm?abstract_id=2542303; Marcus, supra note 5, at 61 .

15. Marcus, supra note 5, at 27 n.138.

16. Perry v. Schwarzenegger, 704 F. Supp. 2d 921, 1004 (N.D. Cal. 2010). 
contracted outside Idaho or prohibit otherwise qualified same-sex couples from marrying in Idaho. ${ }^{17}$

Or the order from Judge Daniel D. Crabtree of the District of Kansas:

Defendants are hereby enjoined from enforcing or applying Article 15, § 16 of the Kansas Constitution and K.S.A. § 23-2501 and any other Kansas statute, law, policy or practice that prohibits issuance of marriage licenses to same-sex couples in Kansas. Defendants may not refuse to issue marriage licenses on the basis that applicants are members of the same sex. $^{18}$

State officials generally declined to challenge the scope of these overbroad injunctions, either in the district court at the time of entry or on appeal. And in affirming the invalidity of same-sex marriage bans, courts of appeals generally did not explore or remark on the purported scope or effect of these injunctions.

In fact, however, much of the procedural confusion and controversy in the marriage equality litigation resulted from the failure of attorneys, courts, and the public to understand procedural and remedial issues-about the limited scope of injunctions, about the differences between injunctions and precedent, and about how judgments control real-world behavior and establish constitutional change.

\section{A. Injunctions, Precedents, and Constitutional Compliance}

\section{Injunctions and Precedents}

The "usual rule" is that litigation is conducted "on behalf of the individual named parties only." enjoin enforcement of unconstitutional state laws. A court can "enjoin a defendant only with respect to defendant's treatment of plaintiffs actually before the court, either individually or as part of a certified class. ${ }^{20}$ As Richard Fallon argues, the prospective legal

17. Latta v. Otter, 19 F. Supp. 3d 1054, 1086 (D. Idaho 2014) (emphasis in original).

18. Marie v. Moser, 65 F. Supp. 3d 1175, 1206 (D. Kan. 2014).

19. Califano v. Yamasaki, 442 U.S. 682, 700-01 (1979).

20. LAYCOCK, supra note 5, at 217; see also Marcus, supra note 5, at 27-28. 
effect of a decision pronouncing a law unconstitutional derives from a complex interaction among three distinct doctrines: injunction, preclusion, and precedent. ${ }^{21}$ To understand Fallon's framework, we must understand precisely how precedent functions-that is, how prior judicial decisions regulate the conduct of state officials charged with enforcing a particular state law.

An injunction prohibiting enforcement of a constitutionally invalid law only benefits the named plaintiffs and only binds named defendants. ${ }^{22}$ It also may extend to the party's officers, agents, servants, and employees, as well as "other persons who are in active concert or participation" with the party. ${ }^{23}$ The injunction (and the opinion explaining and justifying the injunction) is directly, immediately, and coercively enforceable against the named defendants and for the benefit of the named plaintiffs. It compels the former to perform (or refrain from performing) some acts for the latter's benefit. Failure to do so would be a direct violation of the injunction, punishable by contempt of court. ${ }^{24}$ A final judgment also has a preclusive effect in future litigation, but, again, only with respect to those parties. ${ }^{25}$

As to nonparties, the force of the judgment and opinion justifying the judgment derives entirely from the doctrine of precedent. ${ }^{26}$ Its precedential force depends entirely on the court that rendered the judgment and where it stands in the judicial hierarchy. ${ }^{27}$ A decision from the U.S. Supreme Court provides binding precedent on every court within the United States, federal and state. A decision from a regional court of appeals provides binding precedent on all federal courts within the circuit, although not necessarily on state courts $^{28}$ and not on other circuits. A decision of a federal district court, however, is not binding on any other federal or state court,

21. Fallon, supra note 6, at 1339-40; Fallon, supra note 6, at 923-24 n.31.

22. Doran v. Salem Inn, Inc., 422 U.S. 922, 931 (1975); Fallon, supra note 6, at 1340. This changes if the litigation is brought as a class action. LAYCOCK, supra note 5, at 217; see infra Part I.D.

23. FED. R. CIV. P. 60(d)(2), (3).

24. In re Debs, 158 U.S. 564, 594 (1895); S.E.C. v. Homa, 514 F.3d 661, 674 (7th Cir. 2008); LAYCOCK, supra note 5, at 4.

25. Fallon, supra note 6 at 1340; Fallon, supra note 6, at 923-24 n.31.

26. Fallon, supra note 6, at 924 n.31; Gary Lawson \& Christopher D. Moore, The Executive Power of Constitutional Interpretation, 81 IOWA L. REV. 1267, 1328 (1996).

27. Randy Kozel, The Scope of Precedent, 113 MICH. L. REV. 185-86 (2014).

28. See generally Amanda Frost, Inferiority Complex: Should State Courts Follow Lower Federal Court Precedent on the Meaning of Federal Law?, 68 VAND. L. REV. 53, 55 (2015); Wayne A. Logan, A House Divided: When State and Lower Federal Courts Disagree on Federal Constitutional Rights, 90 NOTRE DAME L. REV. 235, 236-37 (2014). 
including courts in the same state, district, and even as to the same judge deciding a different case. ${ }^{29}$

Regardless of type, however, precedent never directly regulates executive officials' real-world conduct or obligates them to act (or refrain from acting) in any way. An official's failure to abide by even binding precedent-as opposed to a judgment-is not subject to contempt of court or other direct enforcement. An individual seeking the benefit of precedent must initiate new litigation and obtain a new injunction compelling those officials to act or not act as to them. Precedent will almost certainly drive the judicial resolution (through binding or persuasive force, depending on the court) of that new litigation. In other words, precedent is neither self-enforcing nor directly controlling of real-world conduct of responsible executive officers. Rather, it persuades or influences judges in future litigation seeking new judgments and injunctions against those executive officials. Precedent can be enforced as to those new parties only through that additional step of new litigation; the next court applies precedent to decide the next action involving the next set of parties and enters a judgment and binding injunction as to them. ${ }^{30}$ It is that new judgment and injunction that then directly controls new defendants' real-world conduct as to new plaintiffs and that is directly enforceable through civil contempt.

Subsequent litigation applying precedent can take two forms. First, when the challenged laws are criminal prohibitions enforced through government initiated prosecution or litigation, precedent affects resolution of that new case, requiring or suggesting the dismissal of the prosecution. ${ }^{31}$ Second, similarly situated persons might file a new federal $\S 1983$ action against different defendants to enjoin enforcement of the challenged law as to them. Precedent from the first case invalidating the law will compel or persuade (depending on the issuing court) the same outcome in the new suit. Because bans on same-sex marriage are "enforced" by the relevant official

29. Camreta v. Greene, 131 S. Ct. 2020, 2033 n.7 (2011); ASARCO Inc. v. Kadish, 490 U.S. 605, 617 (1989); Fallon, supra note 6 at 1340; Fallon, supra note 6, at 924 n.31.

30. Cf. Marcus, supra note 5, at manuscript 27-28 (acknowledging that this "remedial parsimony" may seem "hard-hearted and inefficient"); but see Miller v. Davis, No. 15-cv44-DLB (E.D. Ky. Sept. 23, 2015) (unpublished memorandum order explaining extension of injunction and stating that limiting injunction only to parties "would not only create piecemeal litigation, it would be inconsistent with basic principles of justice and fairness"), http://www.washingtonblade.com/content/files/2015/09/Judge-denies-Davis.pdf.

31. Fallon, supra note 6, at 924 n.31; see, e.g., Doran v. Salem Inn, Inc., 422 U.S. 922 , 931 (1975); Steffel v. Thompson, 415 U.S. 452, 456 n.3 (1974). 
declining to issue a marriage license (or some other benefit) to a requesting couple, challenges to those bans involved only the second type of litigation.

The precedent-injunction distinction further maps onto the concept of departmentalism - that federal executive and legislative officials, ${ }^{32}$ as well as state officials, ${ }^{33}$ wield independent power to interpret the Constitution and to act on their own constitutional understandings. And that remains true even when those interpretations depart from, or directly conflict with, judicial interpretations, including interpretations from the Supreme Court. Of course, departmentalism is not universally accepted. ${ }^{34}$ Critics argue that by denying an authoritative judicial voice about constitutional meaning, departmentalism violates the rule of law, creating chaos and uncertainty as to what the law is and how to organize real-world conduct. ${ }^{35}$ But judicial supremacy is neither required by constitutional text nor structure. ${ }^{36}$ And any chaos or conflict might be more feature rather than bug in a system of separation of powers. ${ }^{37}$

Gary Lawson proposes what he calls a middle-ground approach to departmentalism, grounded in the precedent-judgment distinction, that provides a clear stopping point on interbranch conflict. Politicalbranch officials generally must enforce and obey a court's judgment, ${ }^{38}$ the "raw determinations of liability or nonliability (as opposed to the explanations for those determinations embodied in judicial opinions)

32. Lawson \& Moore, supra note 26, at 1269-70; Michael Stokes Paulsen, The Most Dangerous Branch: Executive Power to Say What the Law Is, 81 GEO. L.J. 217, 220 (1994).

33. Gary Lawson, Interpretive Equality as a Structural Imperative (or "Pucker Up and Settle This!”), 20 CONST. COMMENT. 379, 384 (2003).

34. Burt Neurborne, The Binding Quality of Supreme Court Precedent, 61 TuL. L. REV. 991, 992 (1987).

35. Id. at 994; see also Lawson \& Moore, supra note 26, at 1268; Paulsen, supra note 32 , at 333

36. Paulsen, supra note 32, at 221.

37. Lawson, supra note 33, at 384; Lawson \& Moore, supra note 26, at 1329-30. In response to a question about judicial supremacy, Justice Samuel Alito explained that all branches of government "have a duty to adhere to the Constitution like" the Courts do. He stressed in closing, however, that "We are a nation of laws. It is important for people to respect the actions by the branches of government when they are acting within the proper scope of their authority." See Josh Blackman, Justice Alito Reflects on his Tenth Anniversary on \#SCOTUS, JOSH BLACKMAN'S BLOG (Sept. 21, 2015), http://joshblack man.com/blog/2015/09/21/justice-alito-reflects-on-his-tenth-anniversary-on-scotus/.

38. Lawson \& Moore, supra note 26, at 1325-27. Lawson allows for the possibility that an official can disregard a judgment against him or that the President can decline to enforce a judgment, but only in extreme circumstances. $I d$. 
rendered in specific cases." "raw judgment itself: the finding of liability or nonliability and the specification of the remedy" compelling parties to act or refrain from acting. $^{40}$ It does not apply to the reasoning or the legal principles and conclusions that the court used to justify its judgment. ${ }^{41}$ The court's opinion is merely an explanation for its order, having no independent legal force. ${ }^{42}$ The legal conclusions stated in the opinion affect future actors only through precedent or stare decisis, which provides an idea of how future cases may be resolved, while imposing no legal obligation to abide by the reasoning. ${ }^{43} \mathrm{Up}$ to the point of a judgment and injunction against them, therefore, state and federal actors can proceed on, and argue for, their own best understanding of what the Constitution requires, even if it conflicts with the Court's. Once that judgment comes, however, political actors must comply.

Lawson's departmentalism rests on the idea that what makes courts unique is that they decide cases and issue judgments and those judgments control everyone who is subject to them or their obligations. But the power to interpret the Constitution simpliciter is not unique to the courts, but instead resides in all public officials (of all branches and all levels) who swear an oath to uphold the Constitution. $^{44}$ Only when the judicial interpretation is reduced to a judgment does it become supreme-and then only within the limited scope of that judgment. To suggest otherwise would allow a court to expand the scope of its otherwise limited judgment and injunction simply by issuing a statement of reasons and constitutional analysis. ${ }^{45}$

Merging Lawson's departmentalism with Fallon's precedentinjunction distinction offers a new insight, which Kevin Walsh labels "judicial departmentalism." ${ }^{46}$ Because only specific public officials are enjoined only as to specific plaintiffs, the scope of the judgment is necessarily limited. Public officials can continue to act on their competing constitutional understandings as to similarly situated

\footnotetext{
39. Id. at 1271 .

40. Id. at 1327.

41. Id. at $1327,1328$.

42. Wasserman, supra note 7 , at 7 .

43. Lawson \& Moore, supra note 26, at 1328-29.

44. Lawson, supra note 33, at 384; Lawson \& Moore, supra note 26, at 1269-70.

45. Id. at 1328 .

46. Kevin C. Walsh, Combating judicial supremacy through containment and conversion, MIRROR OF JUSTICE (Oct. 9, 2015), http://mirrorofjustice.blogs.com/mirrorof justice/2015/10/combating-judicial-supremacy-through-containment-and-conversion.html.
} 
nonparties, even if those understandings conflict with the opinion supporting the earlier judgment. That interpretive freedom ends as soon as the courts speak as to the new parties and subject the defendants to a new or expanded judgment and injunction. But that judgment comes only after new or expanded litigation and a new judicial order.

To be sure, the result is the same-public officials will abide by binding precedent. But that does not mean we do or should live under a regime of judicial supremacy, in which the executive is bound by judicial interpretation. As Michael Paulsen argues, "we have wrongly described as judicial supremacy what really is coordinacy combined with inevitable (and proper) interpretive restraint by nonjudicial interpreters," ${ }^{47}$ who adhere to the court's particularized judgment of liability and remedy. ${ }^{48}$

\section{What Did the Courts Decide in the Marriage Equality Cases?}

We now get a clearer picture of the real effect of the various marriage equality decisions from the Supreme Court and the lower courts. Obergefell reversed a decision by the Court of Appeals for the Sixth Circuit reviewing district court decisions as to marriage bans in Michigan, Ohio, Kentucky, and Tennessee. The ultimate result was the entry of injunctions prohibiting officials in those states from enforcing those bans and obligating them to issue marriage licenses or recognize the marriages of particular couples bringing each action. ${ }^{49}$ Prior to Obergefell, decisions invalidating and enjoining enforcement of marriage bans and compelling the issuance of marriage licenses in those states, had a similar effect on named defendants as to named plaintiffs. This was true whether those decisions came from federal district courts $^{50}$ or were affirmed by a regional court of appeals. ${ }^{51}$

But none of the injunctions entered in those cases on remand directly compelled officials to issue licenses to similarly situated

47. Paulsen, supra note 32, at 343.

48. Lawson \& Moore, supra note 26, at 1329.

49. See supra note 13 and accompanying text. The Supreme Court's mandate did not issue until twenty-five days after its decision, on July 28, 2015, allowing parties to request reconsideration. The case was remanded to the Sixth Circuit, which in turn remanded the cases to the respective district courts for entry of a permanent injunction and final order.

50. See, e.g., Strawser v. Strange, 44 F. Supp. 3d 1206, 1207-09, 1210 (S.D. Ala. Feb. 12, 2015) (issuance of licenses to four couples); Brenner v. Scott, 999 F. Supp. 2d 1278 (N.D. Fla. 2014) (one couple); Perry v. Schwarzenegger, 704 F. Supp. 2d 921, 1004 (N.D. Cal. 2010) (two couples).

51. See, e.g., Bostic v. Schaefer, 760 F.3d 352 (4th Cir. 2014) (two couples in Virginia); Kitchen v. Herbert, 755 F.3d 1193 (10th Cir. 2014) (three couples in Utah). 
nonparty same-sex couples or to anyone other than the named plaintiffs. Nor did they compel nonparty state officials, such as clerks or judges in other parts of a state or in a different state, to issue licenses to anyone. ${ }^{52}$ The prior judgments affected these people only as precedent to be applied in subsequent litigation. Officials remained free to believe that the prior court-including the Supreme Court-had been wrong in its interpretation of the Fourteenth Amendment, and they could continue to act on that understanding by continuing to deny licenses. These officials also could continue to argue that position in subsequent litigation, even knowing they would lose absent a change in precedent. They became bound to act in a particular way as to new couples only after another court in a separate action involving those different parties applied precedent and reduced it to a judgment against them. Once enjoined, however, these officials become legally obligated as to those parties and subject to civil contempt for noncompliance.

Obergefell, as Supreme Court precedent, bound every federal and state court on the legal proposition that the Fourteenth Amendment prohibits states from denying marriage licenses to samesex couples. ${ }^{53}$ Prior to Obergefell, a district court in Wisconsin or Indiana would have responded similarly to Judge Posner's decision for the Seventh Circuit.

On the other hand, no court would be bound by prior precedent from any district court invalidating a ban or enjoining its enforcement. $^{55}$ Thus, for example, when Judge Callie V.S. Granade of the Southern District of Alabama declared the state ban unconstitutional and enjoined a state official from enforcing it against

52. This point is qualified slightly, depending on the structure of state law and who has the power to issue marriage licenses. Federal Rule of Civil Procedure 65(d) allows a court to enjoin the party's agents and "other persons who are in active concern or participation" with a named defendant. FED. R. CIV. P. 65(d)(2)(C). For example, an injunction against the attorney general would also bind county officials subject to her control or supervision.

53. The latter is highly unlikely given the straightforwardness of the legal issue, the identity of the challenged state laws, and the identity of the challenged conduct (denying licenses or recognition. See Marcus, supra note 5, at manuscript 26-28. Cf. Costanza v. Caldwell, No. 2014-CA-2090, 2015 WL 4094655, at *4 (La. July 7, 2015) (Hughes, J., dissenting) ("Does the 5-4 decision of the United States Supreme Court automatically legalize this type of adoption? While the majority opinion of Justice Kennedy leaves it to the various courts and agencies to hash out these issues, I do not concede the reinterpretation of every statute premised upon traditional marriage.").

54. Baskin v. Bogan, 766 F.3d 648 (7th Cir. 2014).

55. See supra note 50 
four plaintiff couples, ${ }^{56}$ a different district court hearing a challenge to Alabama's ban by a different couple would not have been bound by the injunction or by Judge Granade's analysis. That second court could have performed its own constitutional analysis to reach its own conclusion, without regard or deference towards the earlier decision. ${ }^{57}$ In fact, Judge Granade herself could have reached a different conclusion in a subsequent challenge to the Alabama marriage ban (however unlikely that was to happen).

The extension of Obergefell still required subsequent litigation, which tended to take two forms in the marriage equality campaign. Courts in pending cases either imposed injunctions or lifted stays on existing injunctions, directly binding defendant officials as to plaintiff couples. Prior lower court decisions invalidating state bans and enjoining their enforcement were now unquestionably correct in light

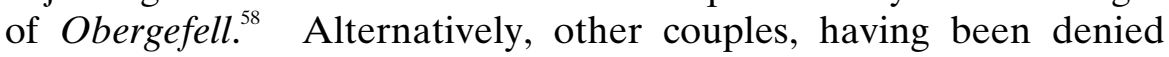
licenses by officials not complying with precedent, had to initiate their own litigation against the appropriate officers, seek a new injunction prohibiting enforcement of the same-sex marriage ban, and compel the defendants to issue licenses to them. ${ }^{59}$ The district court then would apply Obergefell as precedent and compel the official to issue marriage licenses to those plaintiffs, an easy decision that the court likely would make relatively quickly. ${ }^{60}$

The point remains that precedent has no effect until a new court relies on that precedent to speaks to particular state executive officials, as to particular plaintiffs, with respect to a particular law. Until then, state officials remained untethered to the constitutional understanding offered in Obergefell or in any other decision and free

56. Strawser v. Strange, 44 F. Supp. 3d 1206, 1207-10, (S.D. Ala. Feb. 12, 2015).

57. Wasserman, supra note 7, at 6-8.

58. See, e.g., Waters v. Ricketts, 798 F.3d 682 (8th Cir. 2015); Rosenbrahn v. Daugaard, 61 F.3d 862 (8th Cir. 2015); Jernigan v. Crane, 796 F.3d 976 (8th Cir. 2015); Campaign for Southern Equality v. Bryant, 791 F.3d 625 (5th Cir. 2015); DeLeon v. Abbott, 791 F.3d 619 (5th Cir. 2015); Robicheaux v. Caldwell, 791 F.3d 616 (5th Cir. 2015); Robicheaux v. Caldwell, Nos. 13-5090 C/W, 14-97, 14-327, 2015 WL 4090353 (E.D. La. July 2, 2015) (unpublished order imposing injunction).

59. See, e.g., Miller v. Davis, No. 15-cv-00044-DLB, 2015 WL 4866729, at *1 (E.D. Ky. Aug. 12, 2015); Laurel Brubaker Caulkins, Texas Couple Gets Marriage License After Suing for Foot-Dragging, BLOOMBERGBusiness (July 6, 2015), http://www.bloomberg. com/news/articles/2015-07-06/texas-couple-sues-clerk-claiming-foot-dragging-on-gay-marr iage; Robert Wilonsky, Update: 'A Historic Day for Hood County' after lawsuit leads to marriage license, DALlAS MORNING NEWS (July 6, 2015), http://thescoopblog.dallas news.com/2015/07/same-sex-couple-of-27-years-sues-hood-county-clerk-for-refusing-to-iss ue-marriage-license.html/.

60. Miller, 2015 WL 4866729, at *1. 
to abide by their own constitutional understandings in deciding whether to issue licenses or otherwise recognize same-sex marriages. State officials also remained free in subsequent litigation to argue, at a minimum, that prior precedent should be modified or overturned. ${ }^{61}$ Only when the officials lose in that subsequent litigation, and are themselves enjoined from enforcing the challenged laws as to the named plaintiffs, are they judicially obligated to follow the court's constitutional understanding.

\section{B. Voluntary Compliance}

\section{Precedent and Voluntary Compliance}

The marriage equality litigation was atypical. We do not regularly see new plaintiffs having to commence new litigation and secure new judgments and injunctions in the wake of constitutional decisions from the Supreme Court. The reason is that state officials can, and usually will, conform their conduct to precedent as to similarly situated persons. They decline to enforce a challenged law or otherwise engage in conduct as to those people where that conduct has previously been declared unconstitutional as to others. In fact, courts likely issue those inappropriately overbroad injunctions in constitutional cases on the assumption that officials will voluntarily comply, so the scope-of-injunction question never arises. ${ }^{62}$

Importantly, however, it remains a voluntary act of the officials rather than a product of legal or judicial compulsion. Under the departmentalist understanding, executive officials choose to proceed under the new judicial interpretation of the Constitution in carrying out their official conduct, but are not compelled to do so prior to entry of a judgment against them; they retain authority to reach their own constitutional conclusions. ${ }^{63}$ This is so even in the face of binding authority, such as Obergefell or an Article III-final regional court-ofappeals decision. ${ }^{64}$

Perhaps this voluntary compliance derives from agreement with precedent, reached following independent constitutional

61. FED. R. CIV. P. 11(b)(3).

62. LAYCOCK, supra note 5, at 217.

63. See supra notes $46-48$ and accompanying text.

64. See, e.g., Bostic v. Schaefer, 760 F.3d 352 (4th Cir. 2014); Baskin v. Bogan, 766 F.3d 648 (7th Cir. 2014); Kitchen v. Herbert, 755 F.3d 1193 (10th Cir. 2014); see also infra notes $99-100$ and accompanying text. 
deliberation. ${ }^{65}$ Perhaps it is out of convenience. Or perhaps it is out of executive certainty that binding precedent preordains their liability in the next lawsuit, such that the easiest course is to conform to precedent even while believing it wrong. ${ }^{66}$ This last possibility recalls Oliver Wendell Holmes's insistence that law is merely prediction by real-world actors of what courts will do. ${ }^{67}$

It also means that departmental interpretation eventually yields to the judicial interpretation-that is, executive departmentalism yields to judicial departmentalism. While voluntary compliance with precedent (without a further court order) is not compelled, judicial and political processes incentivize it in a number of ways.

First, binding precedent creates a legal certainty that state officials will lose the subsequent litigation and will be ordered to issue licenses to the new couples. Even with a nonbinding district court decision, procedural rules make a new or expanded injunction as to new parties practically likely, even if not compelled by precedent. For example, most federal districts have a related-case rule, whereby cases raising similar legal and factual issues will be assigned to the same judge. ${ }^{68}$ Thus, following Judge Granade's decision requiring one probate judge to issue licenses to four couples, any new constitutional challenge to Alabama's ban in the Southern District of Alabama would have been assigned to Judge Granade, who was practically certain (if not legally required) to reach the same conclusion. ${ }^{69}$

Relatedly, and perhaps more importantly, any official who forces that new lawsuit, loses, and is enjoined would be liable for the new plaintiffs' reasonable attorneys' fees. Every new couple obtaining a new injunction compelling the issuance of a marriage license would qualify as a "prevailing party" in a $\S 1983$ action, having obtained injunctive or declaratory relief. ${ }^{70}$ While forcing the new lawsuit and

65. Paulsen, supra note 32 , at 338 .

66. See id. (describing "executive accommodation in light of the logical implications of the coordinacy of the branches").

67. Oliver Wendell Holmes, The Path of the Law, 10 HARV. L. REV. 457 (1897) ("The object of our study, then, is prediction, the prediction of the incidence of the public force through the instrumentality of the courts.").

68. See, e.g., S.D. ALA. L.R. 3.3(a); see generally Katharine MacFarlane, Analyzing The Southern District Of New York's Amended "Related Cases" Rule: The Process For Challenging Nonrandom Case Assignment Remains Inadequate, 69 N.Y.U. ANN. SURVEY OF AM. L. 699 (2014).

69. Wasserman, supra note 7 , at 8.

70. 42 U.S.C. $§ 1988(b)$ (2012); Lefemine v. Wideman, 133 S. Ct. 9, 11 (2012); Buckhannon Bd. \& Care Home, Inc. v. W. Va. Dep't of Health \& Human Res., 532 U.S. 598, 603-04 (2001); see, e.g., Stipulation and Agreement as to Costs and Attorneys' Fees at 
new injunction may not cost the state, having to pay attorneys' fees for dozens or hundreds of new couples will.

A second, more remote incentive is that the similarly situated couple denied a license might sue not only for an injunction compelling the relevant officials to issue the license, but also for money damages for past injuries caused by denial of the license, which violates the Fourteenth Amendment under Obergefell. Recovering damages depends not on the Constitution, which plainly has been violated by the denial of the license, but on the subconstitutional defense of qualified immunity. ${ }^{71}$ That doctrine provides that a defendant officer is liable for damages only if the right violated was clearly established, such that a reasonable officer would be on notice that his conduct (here, denying marriage licenses to these new same-sex couples) violated the Constitution. ${ }^{72}$ Recent decisions have elaborated on this requirement, insisting that qualified immunity is designed to protect all but the "plainly incompetent," meaning the defense is not lost unless prior precedent places the constitutional question "beyond doubt." too high a level of generality. Instead, precedent must establish the right within at least a factually analogous context.

In addition, a couple also might seek damages not only from the officer who denied the license, but also from the local governmental entity for constitutional harm caused by its formal policies or by the training and supervision of employees by the municipal policymaker. ${ }^{74}$ This turns on a subsidiary question of whether a county clerk, in making office policies with respect to marriage licenses, acts on behalf of the county rather than the state..$^{75}$ One district court concluded that county clerks make policy for the state in Kentucky, precluding this strategy there. ${ }^{76}$

IIII 10-11, Wolf v. Walker, No. 14-CV-64, (W.D. Wis. Mar. 27, 2015), http://pdfserver.am law.com $/ \mathrm{nlj} /$ Wisconsin $\% 20 \mathrm{ssm} \% 20$ fee \%20stipulation.pdf.

71. Buckley v. Fitzsimmons, 509 U.S. 259, 268-69 (1993); Scheurer v. Rhodes, 416 U.S. 232, 245 (1974)

72. Hope v. Pelzer, 536 U.S. 730, 739 (2002).

73. San Francisco v. Sheehan, 135 S. Ct. 1765, 1774 (2015); Plumhoff v. Rickard, 134 S. Ct. 2012, 2023 (2014); Ashcroft v. al-Kidd, 131 S. Ct. 2074, 2085 (2011).

74. Connick v. Thompson, 131 S. Ct. 1350, 1359-60 (2011); Cty. of Los Angeles v. Humphries, 131 S. Ct. 447, 452 (2011); Monell v. Dep't of Soc. Servs., 436 U.S. 658 (1978).

75. McMillian v. Monroe Cty., 520 U.S. 781, 785 (1997).

76. Miller v. Davis, No. 15-cv-00044-DLB, 2015 WL 4866729, at*14 (E.D. Ky. Aug. 12, 2015). 
Following Obergefell, it might appear that a damages action by a same-sex couple is very likely to succeed against truly recalcitrant state officers and offices. A single decision from the Supreme Court declaring that bans on same-sex marriage violate the Fourteenth Amendment should be sufficient to clearly establish that right, given the factual similarity of all flat bans on issuing marriage licenses to couples who want them and who satisfy all other requirements. The whole point of Obergefell is to place "beyond doubt" the question of the constitutional protection for same-sex couples to marry on identical terms as opposite-sex couples.

It is less clear whether damages would have been available in the months prior to Obergefell. The doctrine is in flux as to whether onpoint circuit precedent can clearly establish a right within a circuit. The Supreme Court has assumed it can, without actually deciding the point, ${ }^{77}$ an approach that has cast doubt on the matter. Thus, for example, we do not know if the Seventh Circuit decision in Wolf clearly established the right to marriage equality within that circuit, such that only a plainly incompetent official would have believed he was justified in refusing to recognize or license a same-sex marriage. On the other hand, a single or small number of nonbinding district court decisions almost certainly do not clearly establish a right. In any event, because there was a split among the courts of appeals as of November 2014, the right likely was not clearly established prior to the Court's decision in Obergefell. If "judges thus disagree on a constitutional question," it is unfair to impose money damages on executive officers. $^{78}$

Moreover, qualified immunity must take into account some of the underlying facts and circumstances in defining the right at issue. ${ }^{79}$ Thus, a clerk might be able to argue, at least in early cases, that while Obergefell clearly establishes a broad right of same-sex couples to marry, it does not clearly establish the right to have a specific public official issue that same-sex license even if it offends the official's religious beliefs. ${ }^{80}$ These additional factual wrinkles mean it may take

77. Taylor v. Barkes, 135 S. Ct. 2042, 2045 (2015); Sheehan, 135 S. Ct. at 1776; Reichle v. Howards, 132 S. Ct. 2088, 2094 (2012).

78. Wilson v. Layne, 526 U.S. 603, 618 (1999).

79. Plumhoff v. Rickard, 134 S. Ct. 2012, 2023 (2014).

80. Obergefell v. Hodges, 135 S. Ct. 2584, 2625 (2015) (Roberts, C.J., dissenting); see Miller, 2015 WL 4866729, at *1; see also Robyn Tysver \& Cody Winchester, Out of Nebraska's 93 counties only one-Sioux County-refuses to issue same-sex marriage licenses, ОМАНА.СОМ (July 2, 2015), http://www.omaha.com/news/nebraska/citing-religi ous-belief-clerk-in-sioux-county-nebraska-refuses-to/article_e35b4224-2021-11e5-ac56-0fe 660bec1e7.html. 
some time for the rights in Obergefell to become clearly established in practice.

A final incentive for voluntary compliance is politics. The public and media do not recognize or understand the distinctions among injunctions, judgments, persuasive precedent, and binding precedent. Thus, officials who adhere to formal procedure by awaiting a subsequent suit and injunction, rather than complying with precedent, risk accusations of defying or rebelling against the Constitution and the federal judiciary. This is more or less what happened in Alabama in the months prior to Obergefell. ${ }^{81}$

Ironically, of course, political considerations might disincentivize voluntary compliance. Elected officials may recognize the political benefits of resisting, or at least seeming to resist, unpopular federal precedent, which they can criticize as judicial overreaching. ${ }^{82}$ That seems especially likely with controversial social issues such as samesex marriage. Ultimately, politics may be inextricable from cost. Attorney's fees ${ }^{83}$ and money damages ${ }^{84}$ come from the public fisc. And as much as the public in some states might disagree with Obergefell, there may (and even should) come a point at which the public tires of officials spending public funds to continue losing in federal court.

Given the nature of the same-sex marriage bans being challenged in the states, the multistate litigation campaign made compliance with precedent especially likely. The bans in every state were substantially identical in substance, if not in language-marriage was between one man and one woman and no other combination was entitled to be married, recognized as married, or entitled to receive the benefits, protections, and incidents of marriage. The constitutionally violative state action was the same in every state-the denial by a state official of a marriage license to two people who, but for being of the same sex, were otherwise qualified for marriage in the state. The Ohio marriage ban that Obergefell declared unconstitutional was identical to the ban in Nebraska; the Virginia marriage ban that the Fourth Circuit declared unconstitutional was identical to the South Carolina

81. See Wasserman, supra note 7, at 2-3, 8.

82. See Wasserman, supra note 7, at 16; see also, e.g., Roy Moore on gay marriage ruling: 'Christians are going to be persecuted', AL.COM, (June 28, 2015, 2:15 PM), http://www.al.com/news/index.ssf/2015/06/roy_moore_speaking_at_kimberly.html; Tysver \& Winchester, supra note 80.

83. Perdue v. Kenny A. ex rel Winn, 559 U.S. 542, 558 (2010).

84. Cf. Joanna C. Schwartz, Police Indemnification, 89 N.Y.U. L. REV. 885, 890-91 (2014). 
ban. Thus, there was virtually no way that an official could hope to distinguish precedent in the event of future litigation. ${ }^{85}$ The outcome of future litigation was even more certain than on other controversial constitutional issues, such as whether government officials had taken sufficient steps to integrate the schools. This similarity made it sensible for officials to avoid future litigation that would produce an inevitable defeat.

\section{Voluntary Compliance Before Obergefell}

This network of incentives worked in many places prior to Obergefell. Officials went beyond the limited enforceable scope of the injunction, taking steps to issue licenses to similarly situated couples throughout the state in light of binding or merely persuasive precedent.

For example, thousands of marriage licenses issued in Utah in the eleven days between the District of Utah enjoining enforcement of that state's marriage ban ${ }^{86}$ and the Supreme Court's stay of the injunction. ${ }^{87}$ Although the injunction itself guaranteed licenses only to the three plaintiff couples, clerks issued licenses to all other couples as an act of voluntary compliance with new precedent in anticipation that, if they did not comply, they would be sued and ordered to do so. In an even more extreme example, clerks in Wisconsin voluntarily complied with a district court declaration that the marriage law was void, without even waiting for any injunction to issue. $^{88}$

A more expansive process played out in California. Two samesex couples had sued six executive officer defendants: the Governor, the state attorney general, the director and deputy director of the state Department of Public Health (DPH), and the county clerkrecorders (the officials who actually issue licenses) for two counties. In August 2010, Judge Walker declared that Proposition 8 violated the Fourteenth Amendment and permanently enjoined the six defendant officials from applying or enforcing that law. ${ }^{89}$ The court further directed them to ensure that all persons under their control or supervision similarly did not enforce the ban. ${ }^{90}$ When the defendant state officials declined to appeal the decision and the Supreme Court

85. See Marcus, supra note 5, at 27.

86. Kitchen v. Herbert, 961 F. Supp. 2d 1181 (D. Utah 2013).

87. Herbert v. Kitchen, 134 S. Ct. 893 (2014); see infra Part II.A.

88. See infra Section II.C.3.c. and accompanying text.

89. Perry v. Schwarzenegger, 704 F. Supp. 2d 921, 1003-04 (N.D. Cal. 2010).

90. Id. 
ruled three years later that the sponsors of the voter-enacted samesex marriage ban lacked standing to appeal, ${ }^{91}$ the injunction became final and ready to take effect.

As discussed above, regardless of what the opinion said, the court's injunctive power was limited-the injunction itself could only bind the two named county clerk-recorders to issue licenses to the named couples. Other couples seeking licenses would need to initiate their own litigation against the appropriate clerk-recorder and to obtain their own injunctions. Further, because no one had standing to appeal Perry and establish binding precedent, there would be no binding authority on the matter. Judge Walker's decision would serve only as persuasive authority, leaving the next district court in California free to reach a different conclusion.

Seeking to avoid this problem, nearly three weeks before Hollingsworth was decided, California Attorney General Kamala Harris advised that Judge Walker's injunction would apply to all 58 counties and that "DPH can and should instruct county officials that when the district court's injunction goes into effect, they must resume issuing marriage licenses to and recording the marriages of same-sex couples." ${ }^{22}$ Because DPH controlled county clerk-recorders in administering the state's marriage license and certification laws, ${ }^{93}$ the injunction against the DPH officers effectively enjoined every county clerk-recorder. Of course, even if the injunction reached everyone under DPH control, it still obligated them only as to the named plaintiffs, not the thousands of other couples who might seek licenses. Granting licenses beyond the plaintiff couples reflected further voluntary compliance.

Harris's order preempted discussions percolating among some county officials about challenging, in state or federal court, the scope of the Perry injunction or the attorney general's supervisory authority to compel licenses for all similarly situated couples. ${ }^{94}$ Hours after the

91. The Supreme Court's determination that initiative proponents lacked standing to appeal rendered the district court judgment and the injunction final. See Hollingsworth v. Perry, 133 S. Ct. 2652, 2659 (2013).

92. Letter from Attorney General Kamala Harris to Governor Edmund G. Brown Jr. (June 3, 2013), http://oag.ca.gov/sites/all/files/agweb/pdfs/ht/ag_prop_8_letter.pdf.

93. Id.

94. Marty Lederman, The fate of same-sex marriage in California after Perry, SCOTUSBLOG (June 26, 2013, 11:32 PM), http://www.scotusblog.com/2013/06/the-fate-ofsame-sex-marriage-in-california-after-perry/; Howard Wasserman, What's next in California, PRAWFSBLAWG (June 26, 2013, 11:48 PM), http://prawfsblawg.blogs.com/praw fsblawg/2013/06/whats-next-in-california.html. 
Supreme Court's decision in Hollingsworth, the Ninth Circuit sua sponte dissolved its stay of the district court's injunction. ${ }^{95}$ Circuit Justice Kennedy then denied an application for a stay from the Prop 8 intervenors. ${ }^{96}$ And all county clerk-recorders in California quickly fell in line. ${ }^{97}$

But this is how voluntary compliance operates-the party defendants chose to comply and to order those subject to their supervision to comply. They proceeded as if the injunction protected all couples and entitled them to licenses, without having to pursue further litigation or secure a new injunction. And they ensured that county-level officials did the same through their supervisory authority. In fact, Harris performed the first same-sex marriage for the plaintiffs in Perry hours after the Supreme Court issued its ruling. ${ }^{98}$

Officials in some states even sought to voluntarily comply with court of appeals precedent dealing with a marriage ban from another state within the circuit, even before their own state's ban had been invalidated.

For example, following Tenth Circuit decisions declaring invalid marriage bans in Utah and Oklahoma, ${ }^{99}$ and the Supreme Court denial of certiorari rendering those decisions Article III final, ${ }^{100}$ the chief judge of the Tenth Judicial District in Kansas issued an administrative order directing the clerk of that court (the local official charged with issuing marriage licenses) to issue licenses to same-sex couples. The chief judge was not compelled by any court order to do

95. The Ninth Circuit did not even wait for the Supreme Court's mandate to issue twenty-five days later. Josh Blackman, Prop 8 Supports File Emergency Motion With Circuit Justice Kennedy To Stop SSM In California, JOSH BlACKMAN's BlOG (June 29, 2013), http://joshblackman.com/blog/2013/06/29/prop-8-supports-file-emergency-motionwith-circuit-justice-kennedy-to-stop-ssm-in-california/

96. Id. Hollingsworth v. Perry, Supreme Court Docket No. 12-144, http://www.sup remecourt.gov/search.aspx?filename=/docketfiles/12-144.htm. On July 29, 2013, the judgment finally issued, but, by that point, same-sex marriages were being performed throughout California.

97. Officials in Alabama responded in a very different manner. See Wasserman, supra note 7, at 6-7; see also infra notes 171-78 and accompanying text.

98. Josh Blackman, Constitutional Weddings: Kristin M. Perry and Sandra B. Stier, JOSH BLACKMAN'S BLOG (June 28, 2013), http://joshblackman.com/blog/2013/06/28/cons titutional-weddings-kristin-m-perry-and-sandra-b-stier/.

99. Bishop v. Smith, 760 F.3d 1070 (10th Cir. 2014) (invalidating marriage ban in Oklahoma); Kitchen v. Herbert, 755 F.3d 1193 (10th Cir. 2014) (invalidating marriage ban in Utah).

100. Smith v. Bishop, 135 S. Ct. 271 (2014) (mem.) (case from Oklahoma); Herbert v. Kitchen, 135 S. Ct. 265 (2014) (mem.) (case from Utah). 
this ${ }^{101}$ neither the judge, the clerk, nor any Kansas couple was party to or otherwise affected by the injunctions in the Tenth Circuit cases, which did not even involve Kansas law. But the Kansas judge recognized that the court of appeals decisions constituted binding precedent for the legal proposition that the Fourteenth Amendment required states to recognize same-sex marriages on the same terms as opposite-sex unions. And it was legally certain what would happen next-a Kansas couple seeking a license would sue the clerk in the District of Kansas, the district court would be bound by Bishop and Kitchen to similarly declare the Kansas ban invalid, and it would enjoin the clerk not to enforce the state ban and to issue licenses to the plaintiff couples. The prospect of federal litigation yielding an adverse result was so certain that it made sense to voluntarily comply with binding constitutional precedent, rather than forcing the plaintiffs to file litigation and placing the government on the hook for a new injunction and attorneys' fees. ${ }^{102}$

A similar sequence of events followed in South Carolina after the Fourth Circuit affirmed the invalidation of Virginia's marriage ban. ${ }^{103}$ After the Supreme Court denied certiorari in that case, a probate judge in Charleston County began accepting marriage license applications from same-sex couples and indicated his intention to issue licenses in compliance with Fourth Circuit precedent. ${ }^{104}$ Again, the Fourth Circuit did not address South Carolina law, this probate judge, or South Carolina couples. But it was binding circuit precedent that made it legally certain that, if he declined to issue the licenses and was sued in federal court, he would be enjoined to issue the license, as well as made to pay attorney's fees. Given that prospect, voluntary compliance again made sense. ${ }^{105}$

\section{Voluntary Compliance After Obergefell}

Voluntary compliance was the predominant response to Obergefell. On the day of the decision, fourteen states were not yet

101. Marie v. Moser, 65 F. Supp. 3d 1175, 1185 (D. Kan. 2014).

102. The attempt to voluntarily comply with precedent was thwarted by the Kansas Attorney General, who initiated state court litigation to prevent enforcement of the administrative order. State ex rel. Schmidt v. Moriarty, No. 112, 590 (Kan. Oct. 10, 2014); see infra Section III.A.

103. Bostic v. Schaefer, 760 F.3d 352 (4th Cir. 2014).

104. Condon v. Haley, 21 F. Supp. 3d 572, 580 (D.S.C. 2014).

105. As in Kansas, however, attempt to voluntarily comply was thwarted by the state attorney general through state court litigation. State ex rel Wilson v. Condon, 764 S.E. $2 d$ 247 (S.C. 2014); see infra Part Section III.A. 
issuing same-sex marriage licenses under explicit state law, an Article III-final injunction, or statewide voluntary compliance. State executives in numerous states-including the four states whose laws were at issue before the Court-immediately ordered statewide compliance with the decision and announced plans to issue licenses. ${ }^{106}$ Although these states could have waited for the Court's mandate (due twenty-five days later), most chose not to wait.

The willingness of officials to voluntarily comply with Obergefell as to similarly situated people meant these scope-of-injunction and scope-of-precedent questions never were litigated, at least early on in the process. This is likely because the legal distinction between injunction and precedent carries no practical difference when the precedent is a binding decision from the Supreme Court. ${ }^{107}$ An injunction directly binds the defendant officers as to the party plaintiffs, compelling issuance of licenses to them. Precedent binds the second court, compelling the same conclusion in the subsequent litigation involving the similarly situated nonparty plaintiff couples against these or other defendant officers. The second case necessarily and certainly produces a new injunction compelling those officers to issue licenses to these new couples. The outcome in the subsequent litigation is certain and marriage licenses will issue to all same-sex couples in the state requesting them.

Nevertheless, consider how Mississippi Attorney General Jim Hood described Obergefell immediately after the decision. He recognized that the decision was not immediately effective in Mississippi and would not become so until the Fifth Circuit lifted the stay on the district court injunction. Prior to that, the Supreme Court's mandate-issued in a case involving laws and parties in four other states-did not affect laws, officials, or citizens of Mississippi. Thus, no Mississippi officials were immediately obligated to issue licenses to same-sex couples. ${ }^{108}$ At least implicitly, Hood was justifying the move in terms of the injunction/precedent distinction, effectively demanding an order applicable to him and other state officials as to specific Mississippi couples under Mississippi law.

One of two additional steps was necessary. The Fifth Circuit had to lift the stay and affirm the district court injunction prohibiting

106. See, e.g., Miller v. Davis, No. 15-cv-00044-DLB, 2015 WL 4866729, at *1 (E.D. Ky. Aug. 12, 2015).

107. Fallon, supra note 6, at 1340; Fallon, supra note 6, at 924 n.31.

108. Sarah Fowler \& Kate Royals, Miss A.G.: Same-sex couples cannot yet marry, CLARION-LEDGER (June 28, 2015, 12:11 PM), http://www.clarionledger.com/story/news/2 015/06/26/hinds-not-issuing-same-sex-marriage-licenses/29333011/. 
enforcement of the Mississippi ban, which it did five days after Obergefell. $^{109}$ Alternatively, the district court had to apply Obergefell as precedent in a new action to enjoin enforcement of the Mississippi ban as to new plaintiffs. Again, because Supreme Court precedent is binding on all courts, these second steps were guaranteed to happen in fairly short order and the result was preordained. But state officials could, consistent with their constitutional oath and public obligations, choose to await completion of the formal process, if they were willing to bear the litigation costs and the political fallout.

Controversies over implementation of judicial decisions and orders, both before and after Obergefell, predictably sparked comparisons to Massive Resistance to Brown v. Board of Education and school desegregation. ${ }^{110}$ Following Brown, officials in many states refused to stop enforcing laws requiring segregated schools or to take steps to move their systems towards integration. ${ }^{111}$ It took years of new lawsuits and new (often narrow) injunctions in different states, ${ }^{112}$ a Supreme Court decision broadly asserting supreme judicial authority to declare constitutional meaning, ${ }^{113}$ and political pressure ${ }^{114}$ before something resembling integration began to take hold.

Beyond the pejorative term "Massive Resistance," what really happened after Brown was simply refusal by state officials to voluntary comply with precedent-even precedent from the Supreme Court-in the absence of a judgment and injunction binding on them as to particular plaintiffs. Again, however, this was both substantively and procedurally permissible, in light of departmentalism and the necessarily limited reach of judgments and judicial orders. ${ }^{115}$ At worst, state officials failed to accommodate the realities of coordinate interpretation in not deferring to the Supreme Court when the result

109. See cases cited supra note 59.

110. Wasserman, supra note 7, at 2, 9-10; see Mark Joseph Stern, Resistance to Desegregation or Same-Sex Marriage, SLATE (July 6, 2015), http://www.slate.com/blogs/out ward/2015/07/06/segregation_or_same_sex_marriage_take_our_quiz.html (offering quiz on whether statements were made in response to Obergefell or desegregation).

111. Michael J. Klarman, From Jim Crow to Civil Rights: The Supreme COURT AND THE STRUGGLE FOR RACIAL EQUALITY 328-29, 330-31, 385 (2004); Carroll, supra note 14, at 14-15; David Marcus, Flawed But Noble: Desegregation Litigation and Its Implications for the Modern Class Action, 63 FLA. L. REV. 657, 692-93 (2011).

112. Carroll, supra note 14, at 15; Marcus, supra note 111, at 680-81.

113. Cooper v. Aaron, 358 U.S. 1 (1958). But see Lawson, supra note 33, at 379; Lawson \& Moore, supra note 26, at 1293 n.124.

114. KLARMAN, supra note 111, at 418-19.

115. See supra Part I.A.1. 
of any litigation was inevitable. ${ }^{116}$ Rhetoric aside, the real constitutional problem in Cooper v. Aaron was not that the Little Rock School Board refused to follow Brown, but that the Board attempted to avoid complying with the district court's approved desegregation plan (issued based on Brown's precedential effect) binding the Board as to its constituents. ${ }^{117}$ And the real effect of the Supreme Court's ruling was to deny the Board's request to suspend that injunction, which the district court had granted and the court of appeals had reversed. ${ }^{118}$ Having been enjoined and having been unable to get out of the injunction, the Board's independent constitutional authority ran out as to those parties.

The levels of resistance did not increase much in the early months following Obergefell. There was some early posturing by high-level officials in several southern states. Chief Justice Roy Moore of the Supreme Court of Alabama argued that Obergefell was worse than Plessy v. Ferguson ${ }^{119}$ and Supreme Court decisions about slavery. ${ }^{120}$ Moore also warned that the decision would lead to persecution of Christians. ${ }^{121}$ The Attorney General of Texas opined that individual employees could seek a religious accommodation from issuing licenses to same-sex couples, ${ }^{122}$ while acknowledging that the elected county clerk almost certainly would be sued if no one in the office was able to provide the licenses. ${ }^{123}$

Instead, the prevalent response was voluntary compliance. The overwhelming majority of local officials in every state began issuing licenses to same-sex couples shortly after the decision. Unlike with

\footnotetext{
116. Paulsen, supra note 32 , at 338.

117. Cooper, 358 U.S. at 4-5.

118. Id.; see Justin Driver, Supremacies and the Southern Manifesto, 92 TEX. L. REV. 1053,1058-59 (2014).

119. Jeremy Diamond, Alabama chief justice: Marriage ruling worse than segregation decision, CNN (June 26, 2015), http://www.cnn.com/2015/06/26/politics/roy-moore-conserv atives-gay-marriage-alabama-react/.
}

120. Assoc. Press, supra note 82.

121. Id.

122. Letter from Ken Paxton, Attorney General of Texas, to Dan Patrick, Lt. Governor (June 28, 2015), https://www.texasattorneygeneral.gov/opinions/opinions/ 51paxton/op/2015/kp0025.pdf; see also Josh Blackman, Thoughts on the Texas Attorney General's Decision Concerning Same-Sex Marriage Licenses, JOSH BLACKMAN's BLOG (June 28, 2015), http://joshblackman.com/blog/2015/06/29/thoughts-on-the-texas-attorneygenerals-decision-concerning-same-sex-marriage-licenses/.

123. Letter from Ken Paxton, supra note 122. The letter cited Texas's Religious Freedom Restoration Act as the basis for the accommodation, although it is unclear whether the statute is either necessary or sufficient to protect a public official in the face of a constitutional claim by a same-sex couple denied a license. 
desegregation, public officials who were not inclined to comply resigned and left the scene ${ }^{124}$ or made noise from the wings, but without actively interfering with the enforcement of rights. One report showed that approximately two months after Obergefell, fewer than twenty counties in Southern states were not issuing licenses to same-sex couples. ${ }^{125}$ And thirteen of those were in Alabama, ${ }^{126}$ where some probate judges were waiting for the Supreme Court of Alabama to vacate a mandamus order in light of Obergefell. ${ }^{127}$

The most dramatic resistance came from Kim Davis, Clerk of Rowan County, Kentucky. Under Davis's instructions, the office stopped issuing marriage licenses to any couples, same-or opposite-sex. And she not only refused to issue licenses herself, but prohibited her deputies from doing so. Citing her religious beliefs and the state's Religious Freedom Restoration Act, Davis insisted that, because those licenses were issued in her name as Clerk of the County, she was being compelled to recognize marriages in violation of her deeply held beliefs. Judge David Bunning of the Eastern District of Kentucky applied Obergefell, rejected her religious-liberty arguments, and preliminarily enjoined her to begin issuing licenses. ${ }^{128}$ Both Judge Bunning and the Sixth Circuit declined to stay that injunction.

When Davis continued to refuse to issue licenses, notwithstanding the injunction, Bunning held Davis in civil contempt and jailed her over Labor Day weekend 2015. ${ }^{129}$ This sanction-which the ACLU, representing the plaintiffs, had opposed-made Davis a political celebrity. ${ }^{130}$ Once deputies in the office began issuing

124. Entire Tenn. county clerk's office resigns over same-sex marriage licenses, WKRN (July 2, 2015, 3:47 PM), http://wkrn.com/2015/07/02/entire-tenn-county-clerks-officeresigns-over-same-sex-marriage-licenses/; Mark Joseph Stern, Two Clerks Resigned to Avoid Issuing Gay Marriage Licenses. Good for Them!, SLATE (July 1, 2015, 9:48 AM), http://www.slate.com/blogs/outward/2015/07/01/clerks_resign_to_avoid_issuing_gay_marri age_licenses_good.html.

125. Greg Sargent, A Kentucky clerk is turning away gay couples. But she's a real rarity, WASH. POST (Sept. 1, 2015), https://www.washingtonpost.com/blogs/plum-line/wp/2 015/09/01/a-kentucky-clerk-is-turning-away-gay-couples-but-shes-a-real-rarity/.

126. Id

127. See infra notes 157-59 and accompanying text.

128. Miller v. Davis, No. 15-cv-00044-DLB, 2015 WL 4866729, at*1 (E.D. Ky. Aug. 12, 2015).

129. Miller v. Davis, No. 15-cv-44-DLB, (ED. Ky. Sept. 3, 2015) (minute order), https://www.justsecurity.org/wp-content/uploads/2015/09/davis.contempt.order_.pdf.

130. Maxwell Tani, Kim Davis, the jailed clerk who refused to give out gay marriage licenses, was just honored like a rock star at a surreal rally, BUSINESS INSIDER (Sept. 8, 
licenses, Bunning lifted the contempt order and released Davis after five days, contingent on her not interfering with her deputies. ${ }^{131}$

Bunning also clarified that the injunction required that licenses be issued to all legally eligible couples, not only the named plaintiffs. ${ }^{132}$ Unfortunately, his explanation for that extension showed the typical misunderstanding of the limited scope of his equitable power:

Had the Court declined to clarify that its ruling applied to all eligible couples seeking a marriage license in Rowan County, it would have effectively granted Plaintiffs' request for injunctive relief and left other eligible couples at the mercy of Davis' "no marriage licenses" policy, which the Court found to be in violation of the Supreme Court's decision in Obergefell v. Hodges, 135 S. Ct. 2584 (2015). Such an approach would not only create piecemeal litigation, it would be inconsistent with basic principles of justice and fairness. Thus, when the need arose, the Court clarified that its ruling applied with equal force to all marriage license applicants in Rowan County, regardless of their involvement in this litigation. ${ }^{133}$

While Judge Bunning's heart was no doubt in the right place, the reasoning is inconsistent with the limited scope of a court's injunctive

2015, 4:06 PM), http://www.businessinsider.com/kim-davis-eye-of-the-tiger-jail-2015-9. For a discussion of whether incarceration was even necessary, see Samuel Bagenstos, Kentucky Clerk Kim Davis Never Should Have Gone to Jail, THE NEW REPUBLIC (Sept. 8, 2015), http://www.newrepublic.com/article/122758/kentucky-clerk-kim-davis-never-shouldhave-gone-jail; Marty Lederman, Does anyone have any idea what's happening with marriages in Rowan County, Kentucky?, BALKINIZATION (Sept. 5, 2015), http://balkin .blogspot.com/2015/09/does-anyone-have-any-idea-whats.html.

131. Miller v. Davis, No. 15-cv-44-DLB, (E.D. Ky. Sept. 8, 2015) (order for the release of Kim Davis), https://www.justsecurity.org/wp-content/uploads/2015/09/bunning .lift_.pdf. The last piece of that order somewhat hearkens back to the 1960s, where a district court similarly enjoined Alabama Governor George Wallace from interfering with other state officials in complying with injunctions to integrate schools. See United States v. Wallace, 218 F. Supp. 290, 292 (N.D. Ala. 1963); Wasserman supra note 7, at 3, 9.

132. Miller v. Davis, No. 15-cv-44-DLB, (E.D. Ky. Sept. 3, 2015) (order granting preliminary injunction), https://www.justsecurity.org/wp-content/uploads/2015/09/davis.inj unction.amended.pdf.

133. Miller v. Davis, No. 15-cv-44-DLB, at *3-4 (E.D. Ky. Sept. 23, 2015) (mem.), http:// www.washingtonblade.com/content/files/2015/09/Judge-denies-Davis.pdf (emphasis added); see also Howard Wasserman, Justice and Fairness v. Procedure, PRAWFSBLAWG (Sept. 24, 2015), http://prawfsblawg.blogs.com/prawfsblawg/2015/09/justice-and-fairness-v-procedure.ht $\mathrm{ml}$. 
power. In moving to extend the injunction, the plaintiffs had offered a more plausible justification - that a pending motion for certification of a Rule 23(b)(2) class made the broader preliminary injunction appropriate to protect the interests of putative class members. ${ }^{134}$ But the court declined to follow that path, leaving the class issue untouched and leaving one issue on which he might be vulnerable for reversal on appeal.

Other noncompliance was more symbolic than real. For example, several weeks after Obergefell, the clerk in Hood County, Texas, refused to issue a license to a same-sex couple, purportedly because the office lacked the proper forms; when the couple filed a civil action in the Northern District of Texas, the clerk issued the license within a matter of hours. ${ }^{135}$

It might be tempting to argue that the different response reflects present-day society being more receptive to social change, including judicially created social change. But two other possibilities carry greater explanatory power. One explanation is administrative. States could drag their feet post-Brown in part because of the massive restructuring of state law and the operation of public schools necessary to achieve integration. When the Supreme Court ordered states to comply with Brown with "all deliberate speed," ${ }^{136}$ it recognized that the demand for forward progress had to be balanced against these executive and financial burdens. But no such administrative burdens attach to approving or recognizing same-sex marriages, except perhaps some de minimis costs in creating new marriage license forms (that, for example, have two spaces for "Applicant" rather than one for "Husband" and one for "Wife"). This has two effects. First, it becomes more difficult for officials to rely on anything other than "I disagree with the Supreme Court" to justify noncompliance, which may not be a politically feasible position. Second, federal courts hearing the lawsuits necessitated by noncompliance are likely to be unsympathetic to defendant officials and quick to enjoin them to recognize same-sex marriages in the absence of countervailing state interests.

134. Miller v. Davis, No. 15-cv-44-DLB, 2015 WL 4747531 (E.D. Ky. Aug. 2, 2015) (mem.); see also infra Part I.D.

135. Caulkins, supra note 59; Wilonsky, supra note 59; see Howard Wasserman, What can plaintiffs sue for after Obergefell, PRAWFSBLAWG (July 6, 2015), http://prawfsblawg. blogs.com/prawfsblawg/2015/07/what-plaintiffs-can-sue-for-after-obergefell.html.

136. Brown v. Bd. of Educ., 349 U.S. 294, 301 (1955). 
A second explanation is procedural - the incentives for voluntary compliance are more powerful today than in the period of Massive Resistance following Brown. Actions for damages under $\S 1983$ were not a significant part of the civil rights landscape in the years just after Brown. It was not until several years later that the Supreme Court recognized that public officials are subject to liability even when they act contrary to state law $^{137}$ and that local governments are liable for damages for constitutional harm resulting from their official policies. ${ }^{138}$ Further, prevailing civil rights plaintiffs were not entitled to attorney's fees until Congress enacted the Civil Rights Attorney's Fees Award Act of $1976,{ }^{139}$ legislation explicitly designed to offer plaintiffs a greater chance at obtaining constitutional relief by providing competent counsel. ${ }^{140}$ These developments made Massive Resistance to same-sex marriage significantly more expensive than it was fifty years earlier, as fees easily could run into the hundreds-ofthousands of dollars, as Rowan County has discovered. It made fiscal sense for state and county officials to defer to the Supreme Court's interpretation in Obergefell and avoid further interbranch conflictto practice what Michael Paulsen calls "coordinacy."

\section{The Limits of Persuasive Authority}

The concepts of precedent and injunction overlap, at least as a practical matter, when precedent is binding. ${ }^{141}$ Even if not bound by a judgment and even if free to reach different constitutional conclusions, state officials are likely to comply with circuit or Supreme Court precedent as to similarly situated parties. They know that binding precedent guarantees that they will lose in any subsequent litigation, become subject to an injunction, and be made to pay attorneys' fees and perhaps damages. Thus, the cheapest, simplest, and likely least controversial move is for officials to act as if they are bound by a precedent. ${ }^{142}$ This explains Nebraska's postObergefell concession in the Eighth Circuit that it would abide by the Court's precedent and no longer attempt to enforce its marriage ban

137. Monroe v. Pape, 365 U.S. 167 (1961)

138. Monell v. Dep't of Soc. Servs., 436 U.S. 658 (1978).

139. Pub. L. 94-559, 90 Stat. 2641 (1976), codified at 42 U.S.C. $\$ 1988(b)$.

140. Evans v. Jeff D., 475 U.S. 717, 730 (1986); see also Monell, 436 U.S. at 751-52 (Brennan, J., dissenting).

141. Fallon, supra note 6 at 1340; Fallon, supra note 6, at 924 n.31.

142. Supra Part I.B. 
against the plaintiffs, ${ }^{143}$ although not bound by the judgment in the case.

On the other hand, the concepts diverge when comparing district court precedent, which is merely persuasive, to injunctions. Attorney General Harris' quick voluntary compliance in California preempted discussions percolating among some county officials about challenging, in state or federal court, the scope of the district court injunction in Perry or the attorney general's supervisory authority to compel them to issue licenses to all similarly situated couples. ${ }^{144}$

The effect of the gap between persuasive precedent and injunction was illustrated by a series of genuinely wild and misunderstood litigation moves in Florida and Alabama during the six months prior to Obergefell. Judges in the Northern District of Florida and the Southern District of Alabama declared their respective state marriage bans unconstitutional and issued broad injunctions prohibiting the defendant officers from enforcing the laws. ${ }^{145}$ Both courts stayed their orders only for short periods, to give state officials time to seek stays from reviewing courts. ${ }^{146}$ After those appeals proved unsuccessful, both injunctions took effect. ${ }^{147}$ The plaintiff couples obviously were entitled to marriage licenses from the named defendants, on pain of contempt. But no one-not the courts, the litigants, the media, or the public-quite grasped what this meant for the state as a whole, for similarly situated couples not protected by the injunction, or for other state officials not bound by the injunction.

In both states, the statewide organization for the local officials (county clerks in Florida, probate judges in Alabama) charged with issuing marriage licenses took the position that the injunction only bound the named defendants to issue licenses to the named plaintiffs,

143. Appellants Suggestion of Mootness and Motion to Vacate Preliminary Injunction, Waters v. Ricketts, 798 F.3d 682 (8th Cir. 2015) (No. 15-452), http://files.eqcf. org/wp-content/uploads/2015/06/12706015-Mootness-and-Motion-to-Vacate-PI-.pdf.

144. Lederman, supra note 94; Wasserman, supra note 7; supra notes 89-98 and accompanying text.

145. See, e.g., Strawser v. Strange, 44 F. Supp. 3d 1206, 1207 (S.D. Ala. Feb. 12, 2015); Searcy v. Strange, 81 F. Supp. 3d 1285, 1291 (S.D. Ala. Jan. 23, 2015); Brenner v. Scott, 999 F. Supp. 2d 1278 (N.D. Fla. 2014).

146. Strawser, 44 F. Supp. 3d at 1207; Searcy v. Strange, No. 14-0208-CG-N, 2015 WL 328825, slip op. at 3 (S.D. Ala., filed Jan. 25, 2015); Brenner, 999 F. Supp. 2d at 1293.

147. Strange v. Searcy, 135 S. Ct. 940 (2015); Armstrong v. Brenner, 135 S. Ct. 890 (2015); see supra Part I.D. 
but had no effect beyond those parties. ${ }^{148}$ They advised their members that they were not obligated to issue licenses to any other couples and, indeed, were still prohibited from doing so by state law. In Alabama, Chief Justice Roy Moore asserted his authority as the chief administrative officer of the state courts to advise against ${ }^{149}$ and then prohibit ${ }^{150}$ probate judges from issuing licenses. Moore emphasized the limited scope of the district court's injunction, its nonapplication to nonparty probate judges, and the limited precedential authority of district court decisions.

In response, federal courts in both states issued orders "clarifying" their injunctions. Both judges acknowledged that their injunctions did not compel any nondefendant officers to issue licenses and did not compel issuance of licenses to any nonplaintiff couples. ${ }^{151}$ But, both judges insisted, "the Constitution"152 did require issuance of licenses to other couples by nondefendant officials. And both courts punctuated this point by recalling historical resistance to desegregation decrees and constitutional change. ${ }^{153}$ It is not clear what the judges hoped to convey or what they meant by saying "the Constitution" requires anything. At best, it is a point about precedent - the Constitution as interpreted by that district judge in an earlier case requires issuance of the licenses. Indeed, both judges expressly, and properly, recognized that new couples could bring new lawsuits and successfully obtain injunctions and attorney's fees in light of that precedent. ${ }^{154}$

What both courts as well as most observers missed is that this interpretation, as precedent, was persuasive only. "The Constitution"

148. Memorandum from Attorneys to FACC (Dec. 15, 2014), https://www.scribd.com/ doc/250336675/Greenberg-Traurig-Revised-Memo-December-15-2014; Michael Finch II, Alabama Probate Judges Association Says Not to Issue Marriage Licenses to Same-Sex Couples on Monday, AL.COM (Jan. 25, 2015, 5:58 PM), http://www.al.com/news/mobile/ index.ssf/2015/01/alabama_probate_court_judges_gay_marriage.html.

149. Memorandum from Chief Justice Roy S. Moore to Ala. Probate Judges (Feb. 3, 2015), https://www.scribd.com/doc/272411089/Chief-Justice-Moore-s-Memorandum.

150. Admin. Order of the Chief Justice of the Supreme Court (Feb. 8, 2015), https://www.scribd.com/doc/272411125/CJ-Moore-Order-to-Ala-Probate-Judges.

151. Searcy v. Strange, No. 14-0208-CG-N (S.D. Ala. Jan. 28, 2015) (order clarifying judgment), https://www.scribd.com/doc/272411158/Searcy-v-Strange-1-28-15; Brenner v. Scott, No. 4:14-cv-107-RH/CAS, 2015 WL 44260, at *1 (N.D. Fla. 2015) (order on the scope of the preliminary injunction).

152. Searcy v. Strange, No. 14-0208-CG-N (S.D. Ala. Jan. 28, 2015) (order clarifying judgment) (emphasis added), https://www.scribd.com/doc/272411158/Searcy-v-Strange-128-15; Brenner, 2015 WL 44260, at *1 (emphasis in original).

153. Id.

154. Id. 
required issuance of licenses only because one district judge in a single judicial opinion had so interpreted it. But this interpretation was not binding on any other court or judge in any other case, unless that second court chose to follow it. And because precedent does not bind anyone outside of a court order, state officials could continue deciding for themselves what the Constitution meant and what it required.

Officials knew that the next court-including even that same judge-might reach a different conclusion on the constitutional question when these couples initiated new litigation. Unlike with Supreme Court or court of appeals precedent declaring what "the Constitution" required, district court precedent did not preordain the outcome of subsequent litigation. However unlikely a different result might have been-especially if the action were brought before the same judge-the legal possibility remained.

This, in turn, means that persuasive authority offers less incentive for officials to voluntarily comply rather than continuing to follow their own constitutional interpretation and fight the issue. Indeed, the compliance incentives worked very differently in the two states. In Florida, the practical reality prevailed. Both the state association of county clerks ${ }^{155}$ and the state attorney general ${ }^{156}$ responded to the clarified order by acceding to clerks issuing licenses without awaiting further lawsuits, orders, or appeals.

The clarifying order was far less effective in Alabama. While some county officials began issuing licenses in response to the clarified order, far from all complied. ${ }^{157}$ What followed instead in Alabama was an escalating game of litigation chicken amid a circus of public confusion, which one of us discussed in detail elsewhere. ${ }^{158}$ The Supreme Court of Alabama exercised its original jurisdiction to issue a writ of mandamus prohibiting all state probate judges, other than those bound by the federal injunction, from issuing marriage licenses to same-sex couples. ${ }^{159}$ Through it all rang comparisons of ongoing

155. Howard Wasserman, The Process of Marriage Equality, Redux, PRAWFsBLAwG (Jan. 3, 2015, 9:31 AM), http://prawfsblawg.blogs.com/prawfsblawg/2015/01/the-process-ofmarriage-equality-redux.html.

156. News Release, Attorney General Pam Biondi, Attorney General Pam Bondi's Statement Regarding Judge Hinkle's Order (Jan. 1, 2015), http://www.myfloridalegal.com/ newsrel.nsf/newsreleases/891D80F35B6D0B6985257DC0007E5358.

157. Wasserman, supra note 7, at 6,9.

158. Id. at $10-11$.

159. Ex parte Alabama ex rel. Ala. Policy Inst., No. 1140460, 2015 WL 892752 (Ala. Mar. 3, 2015); Wasserman, supra note 7, at 211-12. In response, the plaintiffs converted 
events to former Alabama Governor George Wallace and resistance to integration, with critics decrying Alabama's "defiance" and "rebellion" against the federal judiciary and the Constitution. ${ }^{160}$

But this criticism misunderstood the nature of judicial relief and the judicial process, the distinction between injunction and precedent and the limited imperative for state officials to voluntarily comply with precedent. ${ }^{161}$ In the end, it created a few weeks of intense public focus on that state, while illustrating the all-too-common gap between legal reality and popular rhetoric.

\section{Civil-Rights Injunction Class Actions}

The way to close the practical gap between an injunction and persuasive district court precedent is through a class action. Federal Rule of Civil Procedure 23(b)(2) permits class actions where "the party opposing the class has acted or refused to act on grounds that apply generally to the class, so that final injunctive relief or corresponding declaratory relief is appropriate respecting the class as a whole." 162 The Supreme Court promulgated the rule in 1966 to facilitate civil rights actions seeking injunctive relief applicable to broad groups of plaintiffs and defendants. This new procedural device was an explicit response to Massive Resistance and the experience with post-Brown desegregation litigation. In cases involving other schools and other plaintiffs, courts often accorded relief only to the named individuals, such as by ordering them to be admitted into previously all-white schools. But they did not provide the broad structural relief of integrating the schools in a way that would benefit a broad class of people. ${ }^{163}$

Class status in civil rights litigation resolves that inefficiency by allowing for relief beyond the named individual plaintiffs and defendants. ${ }^{164}$ Certification enables the court to legitimately impose a broader injunction affording relief to all similarly situated people against all similarly situated officers. ${ }^{165}$ These broader injunctions can directly protect everyone in the class and directly obligate all officials

\footnotetext{
the pending federal suit into a class action, applicable to all same-sex couples seeking licenses against every probate judge in the state. Wasserman, supra note 7 , at 13 ; see infra Part I.D.

160. Id. at 11-12.

161. Id.

162. FED. R. CIV. P. 23(b)(2).

163. Carroll, supra note 14, at 15-16; Marcus, supra note 111, at 702-08; Marcus, supra note 5 , at 6-7.

164. LAYCOCK, supra note 5, at 217; Marcus, supra note 5, at 28.

165. LAYCOCK, supra note 5, at 217.
} 
to perform (or refrain from performing) some act with respect to every class member. Because every similarly situated person is protected by and subject to the class judgment, no one is left to rely on subsequent litigation and the indirect precedential force of the prior decision. And the obligations imposed on the defendants extend to all class members.

Class certification seems particularly appropriate in marriage equality litigation, since the underlying facts were identical in every case and there was no possibility of legal, factual, remedial, or administrative differences among plaintiffs. ${ }^{166}$ Same-sex couples wanted to get married, took the necessary steps to do so, and were denied licenses by state officials following express state law prohibiting couples from marrying because they were of the same sex. The remedy would be the same for all couples-prohibiting state administrators from enforcing the marriage ban and obligating them to issue marriage licenses to all class members. David Marcus categorizes this type of public-interest class action as involving necessarily interdependent claims with plausibly indivisible remedies-state law and state officials treated every couple the same, although an injunction ordering licenses to one couple but not others remained plausible. ${ }^{167} \mathrm{He}$ calls these the "paradigmatic" candidates for 23(b)(2) certification. ${ }^{168}$

At the same time, Marcus recognizes that class treatment may be less necessary in these cases, given the plausibility of each couple pursuing individual litigation. ${ }^{169}$ Moreover, the likelihood of voluntary compliance with precedent declaring a statute unconstitutional, may provide a basis for government officials to argue and courts to conclude, that class treatment is unnecessary. ${ }^{170}$

166. Carroll, supra note 14, at 37; Marcus, supra note 14, at 61.

167. Marcus, supra note 5, at 27.

168. Id. at 50-51.

169. Id. at 27-28.

170. Mills v. Dist. of Columbia, 266 F.R.D. 20, 22 (D.D.C. 2010) (quoting Alliance to End Repression, 565 F.2d at 980); see also Galvan v. Levine, 490 F.2d 1255, 1261 (2d Cir. 1973) (Friendly, J.) (affirming the district court's denial of class certification on the ground that "the judgment run[s] to the benefit not only of the named plaintiffs but of all other similarly situated" claimants and the "State has made clear that it understands the judgment to bind it with respect to all claimants"). Virginia made this argument in opposition to class certification. See State Defendants' Brief in Opposition to Plaintiffs' Motion for Class Certification at *5-6, Harris v. McDonnell, 988 F. Supp. 2d 603 (W.D. Va. Dec. 23, 2013) (No. 5:13-cv-77), https://www.scribd.com/doc/274519731/30-State-Defen dants-Brief-in-Opp-to-Plff-Mot-for-Class-Cert-8-30-13. 
In response to the Supreme Court of Alabama's mandamus order, and some state officials continuing to refuse to voluntarily comply with district court precedent, ${ }^{171}$ the Alabama plaintiffs turned to the injunctive class action. ${ }^{172}$ Judge Granade certified a plaintiff class defined as:

All persons in Alabama who wish to obtain a marriage license in order to marry a person of the same sex and to have the marriage recognized under Alabama law, and who are unable to do so because of the enforcement of Alabama's laws prohibiting the issuance of marriage licenses to same sex couples and barring recognition of their marriages. ${ }^{173}$

The defendant class was defined as:

All Alabama county probate judges who are enforcing or in the future may enforce Alabama's laws barring the issuance of marriage licenses to same-sex couples and refusing to recognize their marriages. ${ }^{174}$

In a separate order, Judge Granade extended the preliminary injunction, previously entered against one probate judge in favor of four couples, to prohibit the defendant class from enforcing the state's same-sex marriage ban. The order further required them to issue marriage licenses to any member of the plaintiff class who followed the proper steps towards obtaining a license. This extended injunction required every Alabama probate judge to issue licenses to any same-sex couples in Alabama who requested one, with every judge subject to contempt for noncompliance. ${ }^{175}$

Recognizing the "imminent" resolution of Obergefell, however, Judge Granade stayed the class injunction "until the Supreme Court issues its ruling." ${ }^{176}$ Following Obergefell, the plaintiffs argued, and Judge Granade agreed, that the stay lifted as soon as the Court issued its decision on June 26. The class-wide preliminary injunction

171. Supra notes $145-60$ and accompanying text.

172. Cf. FED. R. CIV. P. 23(b)(1), (2) (establishing standards for class certification).

173. Strawser v. Strange, No. 14-0424-CG-C, 2015 WL 2449251, at*1 (S.D. Ala. May 21, 2015).

174. Id.

175. Strawser, 2015 WL 2449468, at *1.

176. Id. at *6. 
became immediately effective and binding on every probate judge in the state. ${ }^{177}$ In other words, precedent was converted into an injunction, and because of class certification, the injunction bound all possible similarly situated defendants and ran in favor of all possible similarly situated plaintiffs.

While the days immediately following Obergefell were marked by scattered attempts by some probate judges to avoid issuing licenses to same-sex couples or to avoid issuing licenses at all, ${ }^{178}$ the now effective class injunction quickly ended those efforts by ensuring compliance without need for that additional step. A couple denied a license by a probate judge would not have to initiate a new lawsuit or obtain a new injunction. They instead could go directly to Judge Granade for an order enforcing the existing injunction, with no further constitutional analysis required. The court would promptly order the probate judge to issue licenses under the terms of the injunction, with failure to comply sanctioned by civil contempt.

The post-Obergefell confrontation in Rowan County, Kentucky, further illustrates the benefits of the class action strategy. The day after Judge Bunning enjoined Rowan County Clerk Kim Davis (and her deputies) from refusing to issue licenses, two couples were denied licenses-one was a party to the case, and the other wasn't. ${ }^{179}$ Procedurally this was permissible as to the latter, because the injunction only compelled the clerk to issue licenses to four named couples. It was impermissible, however, as to the former, and could have placed Davis in contempt. ${ }^{180}$ Of course, the plaintiffs recognized these possibilities and had sought class certification; but the court, without explanation, declined to rule on the request. That failure, in turn, called into question the court's later expansion of the injunction beyond the parties to all eligible persons seeking marriage licenses. ${ }^{181}$

\section{E. What if Obergefell had come out the other way?}

A final lens on the precedent/injunction distinction in marriage equality litigation is through a counter-factual: What would have

177. Strawser v. Strange, No. 14-0424-CG-C (S.D. Ala. July 1, 2015) (order clarifying preliminary injunction), http://www.nclrights.org/wp-content/uploads/2015/07/AlabamaJudge-Clarification-Order.pdf.

178. See, e.g., Wasserman, supra note 7, at 15; see supra notes 106-27 and accompanying text.

179. Wasserman, supra note 7.

180. As discussed previously, see supra notes 22-25, 49-51 and accompanying text.

181. Supra notes 26-31, 52-61 and accompanying text. 
happened, procedurally, had the Supreme Court gone the other way in Obergefell and ruled that the Fourteenth Amendment did not protect the right of same-sex couples to marry?

In states under Article III-final injunctions prohibiting enforcement of the same-sex marriage ban, ${ }^{182}$ state attorneys general likely would have moved in the district courts under Federal Rule of Civil Procedure 60(b) to vacate the injunctions in light of the binding change in constitutional law. ${ }^{183}$ In fact, however, the precedentinjunction divide makes this move unnecessary. Because the injunctions only prohibited enforcement of the marriage bans as to the named plaintiffs, the states had already satisfied those judgments when those same-sex couples received marriage licenses or otherwise had their marriages recognized.

All other licenses were issued to same-sex couples in those states on the strength of officials' voluntary compliance with that regionally binding precedent. Of course, that voluntary compliance properly would cease in light of superseding nationally binding precedent. As soon as the counter-factual Obergefell came out, a state official could decline to issue any further licenses, knowing that, if sued by new couples, the district court would not find him liable or enjoin him to issue licenses. In other words, the state could alter its voluntary, precedent-guided behavior. There would be no need to return to court for permission to do so. Further, the states would have no ongoing procedural duty to recognize those marriage licenses that were validly issued during the pendency of the litigation. ${ }^{184}$

In states in which the injunction had not become Article III-final, the state could ask the court of appeals to reverse the district court in light of the new precedent and the change to Fourteenth Amendment law. Courts of appeals generally apply the law in effect at the time it decides a case, even if the law has changed subsequent to the trial court decision. ${ }^{185}$ Again, however, the revised judgment is only

182. This included California, Oregon, Utah, Oklahoma, Virginia, North Carolina, Wisconsin, and Indiana.

183. Agostini v. Felton, 521 U.S. 203, 239 (1997); Rufo v. Inmates of Suffolk Cty. Jail, 502 U.S. 367, 388 (1992).

184. Two district courts found that the states were obligated to recognize validly issued marriage licenses as a matter of due process. Evans v. Utah, 21 F. Supp. 2d 1192 (D. Utah 2014); Caspar v. Snyder, No. 4:14-cv-11499, 2015 WL 224741 (E.D. Mi. Jan. 15, 2015), https://www.scribd.com/doc/252720181/4-14-cv-11499-46.

185. United States v. Schooner Peggy, 5 U.S. (1 Cranch) 103, 110 (1801) (Marshall, C.J.) ("It is in the general true that the province of an appellate court is only to enquire whether a judgment when rendered was erroneous or not. But if subsequent to the judgment and before the decision of the appellate court, a law intervenes and positively changes the rule which governs, the law must be obeyed, or its obligation denied."). 
necessary as to the named plaintiff couples. As to nonparties, state officials remain in the same situation described above-they could end their voluntary compliance, knowing that, if sued by new couples, the district court would not find them liable or issue an injunction in light of Obergefell. And to the extent the injunction was not stayed pending appeal and the plaintiff couples already had received their licenses, no further steps would have been necessary.

The one case in which state officials would have had to seek formal reversal or vacatur of a district court injunction would have been Strawser in Alabama. Because that injunction had been extended to a class of every probate judge obligated to issue licenses to a class of every same-sex couple seeking a license, the obligation to issue licenses across the state came directly from the injunction, not merely from precedent and voluntary compliance with precedent. The class injunction would remain in force, albeit temporarily. The counter-factual Obergefell would require the court to vacate its judgment, although the defendants still would have had to take the extra step of moving for that relief. This again demonstrates how the class action device affects the injunction/precedent line.

\section{Stays, Cert Denials, and the Supreme Court}

After district courts began enjoining enforcement of same-sex marriage bans and compelling the issuance of licenses and recognition of same-sex marriages, the judges confronted when and how those injunctions should take effect. The question of whether to stay a judgment pending appeal, and the controversy and confusion it created throughout the Article III judiciary, made marriage equality largely unprecedented as a constitutional-litigation campaign.

We discuss the stay issue in a chronology, divided into four phases, each defined by a different signal from the Court and a broad range of responses to those signals from the lower courts. The initial period involved the sui generis case from the District of Utah, the first post-Windsor decision invalidating a state ban. The eleven-day period from Christmas Eve 2014, when the court invalidated the Beehive state's ban, until January 7, 2014, when the Supreme Court intervened with a stay, was a litigation steeplechase. The second period began after the Utah controversy, with the Supreme Court apparently signaling that lower courts should put on hold any injunctions until the appeals process was completed. This message lasted until October 2014, when the Supreme Court unexpectedly denied certiorari in cases from three circuits, sending a third signal 
that the same-sex marriage bans likely would not withstand Fourteenth Amendment scrutiny, so lower courts should not stay injunctions during the appeals process. The fourth period began in January 2015, when the Court granted certiorari in the case from the Sixth Circuit that became Obergefell, lasting until the Court's decision on the merits in June. During this period, the lower courts split on whether to stay judgments until the Supreme Court finally resolved the issue once and for all.

Events within each period illustrate how different courts read or ignored the prevailing signals from the shadow docket. They also show that the "correct" answer to the stay question, at least for courts relying on Supreme Court signals, arguably shifted in each new period.

\section{A. Injunctions and Stays}

Three themes emerged on the question of stays in the same-sex marriage litigation. First, these cases teed up the question of when lower courts should stay judgments pending review by a higher court. Generally, courts consider four factors in deciding whether to stay a judgment: (1) whether the stay applicant (the loser in the lower court) has made a "strong showing" that he is likely to succeed on the merits of the appeal; (2) whether the applicant will be irreparably injured absent the stay; (3) whether the stay will substantially injure other interested parties; and (4) where the public interest lies. ${ }^{186}$ Although stays and preliminary injunctions are distinction mechanisms, they overlap in function and in the factors governing each. ${ }^{187}$ A preliminary injunction alters the status quo and the stay suspends that alteration, ${ }^{188}$ leaving reviewing courts time and space to "responsibly fulfill their role in the judicial process." "189 But a court must not "reflexively" hold every order in abeyance pending review. ${ }^{190}$ The decision to grant a stay involves the exercise of sound discretion and the propriety of a stay depends on the circumstances of each case. ${ }^{191}$

The likelihood-of-success prong presents two potential difficulties, particularly for the district court that issued the injunction. First, the inquiry requires the court to predict the losing

186. Nken v. Holder, 129 S. Ct. 1749, 1761 (2009) (quoting Hilton v. Braunskill, 481 U.S. 770, 776 (1987)).

187. Id. at $1758,1761$.

188. Id. at 1758 .

189. Id. at 1757 .

190. Id.

191. Id. at 1760 . 
party's likely success before a reviewing court-in other words, predict how a higher court will decide the issue. This prediction departs from a lower court's ordinary approach to legal analysis. ${ }^{192}$ Second, the stay decision may be affected by what one scholar calls "lock in"- the court becomes tied to its position that the plaintiffs were likely to succeed on the merits of their constitutional claim, thereby justifying the injunction in the first instance. ${ }^{193}$ The judge struggles to conceive of the defendants prevailing on the merits on appeal. $^{194}$ In other words, having declared a marriage law unconstitutional, it would be difficult for the same judge to imagine a higher court declaring the law to be constitutional.

The remaining factors, when considered together, seek to balance the need for responsible, unpressured appellate review with the prevailing party's entitlement to prompt execution of orders benefitting them. ${ }^{195}$ Courts are less likely to stay a prohibitory or negative injunction, such as an order barring the government from enforcing a challenged law. For one thing, a negative injunction does not prohibit enforcement of the challenged law against anyone other than the named plaintiffs. ${ }^{196}$ If the injunction is reversed on appeal, the state will have an opportunity to enforce the law, including against the plaintiff. ${ }^{197}$ By contrast, courts might be more likely to stay a mandatory or positive injunction requiring the state to take affirmative steps, which cannot be undone (or can be undone only at great difficulty and cost) should the injunction eventually be reversed. ${ }^{198}$

192. Michael C. Dorf, Prediction and the Rule of Law, 42 UCLA L. REV. 651, 690-93 (1995); compare id. at 679 with Evan H. Caminker, Precedent and Prediction: The Forward-Looking Aspects of Inferior Court Decionmaking, 73 TEX. L. REV. 1, 74 (1994).

193. Kevin J. Lynch, The Lock-In Effect of Preliminary Injunctions, 66 FLA. L. REV. 779,804 (2014).

194. Id.

195. Nken, 129 U.S. at 1757.

196. Doran v. Salem Inn, Inc., 422 U.S. 922, 929 (1975); Steffel v. Thompson, 415 U.S. 452, 456 n.3 (1974).

197. There is a nice question whether conduct engaged in under the protection of a preliminary injunction can be the subject of a later prosecution if the injunction is reversed and lifted. Compare Edgar v. MITE, 457 U.S. 624, 649-50 (1982) (Stevens, J., concurring in part and concurring in the judgment) with id. at 657-59 (Marshall, J., dissenting); see also Mike Dorf, Can a Federal Appeal Court Provide "Grandfather" Status to Utah SameSex Marriages if the District Court Ruling is Later Reversed on Appeal?, DORF ON LAW (Dec. 30, 2013), http://www.dorfonlaw.org/2013/12/can-federal-court-provide-grandfather. html. That question is beyond the scope of this paper.

198. Evans v. Utah, 21 F. Supp. 2d 1192, 1208 (D. Utah 2014) (citing University of Texas v. Camenisch, 451 U.S. 390, 398 (1981)); see also Strange v. Searcy, 135 S. Ct. 940, 
The marriage cases were unique because the injunctions were both prohibitory and mandatory. State officials were prohibited from enforcing bans on same-sex marriage (a negative order) and also were mandated to license or recognize same-sex marriages of the named plaintiffs (a positive order). Thus, without a stay, the plaintiff couples would be legally entitled to marriage licenses and state officials would immediately be obligated to issue them. State officials also would likely voluntarily comply with the precedent created by the (unstayed) judgment and issue licenses to similarly situated couples.

But once a couple has been married, it is difficult for the state to undo that marriage if the judgment were reversed on appeal based on the reviewing court's determination that bans on same-sex marriage are constitutionally valid. States would face two unappealing options. First, the state could continue to recognize a large number of samesex couples as legally married in the state, even though valid state policy would continue to prohibit any other same-sex couples from marrying. Second, and even worse, the state would have to retroactively invalidate recognized marriages and suspend all attendant benefits, including spousal support and custody arrangements, that the couples had come to rely on. ${ }^{199}$ Whether as part of the irreparable harm, substantial injury, or public interest prongs, the possibility of post-litigation chaos loomed in various ways. The way to avoid chaos is to stay the injunction, ensuring that no marriage licenses issue prior to the end of litigation.

Of course, it remains questionable whether chaos qualifies as irreparable harm to the state justifying a stay. William Baude wondered:

[W] hat was the irreparable harm suffered by the state in the absence of a stay, if marriages were provisionally recognized over the summer? . . Or did the Court as a whole intend to finally endorse the categorical claim that "any time a State is enjoined by a court from effectuating statutes enacted by

191 L. Ed. 2d 149 (2015) (Thomas, J., dissenting from denial of application of stay) (citing San Diegans for Mt. Soledad Nat. War Memorial v. Paulson, 548 U. S. 1301 (2006))) (Kennedy, J., in chambers) (staying an injunction requiring a city to remove its religious memorial).

199. Cf. Andrew Koppelman, Too much for Hitler: Why same-sex marriage is irreversible, BALKINIZATION (Oct. 8, 2014), http://balkin.blogspot.com/2014/10/too-muchfor-hitler-why-same-sex.html (arguing that it is "morally impossible" for a state to invalidate marriages at a later date). 
representatives of its people, it suffers a form of irreparable injury."200

The answer may be that the inability to enforce its laws simpliciter is not irreparable harm, but the inability to enforce combined with the chaos of inconsistent marital statuses, and the provisioning of marital benefits, should be irreparable harm.

The second theme is the force and effect of what William Baude calls the Court's shadow docket. These are the summary decisions, stays, cert denials, and other orders that the Court regularly issues, ${ }^{201}$ typically with minimal, if any, briefing, reasoning, or explanation. ${ }^{202}$ Through that shadow docket, the Court (or individual Justices) engage in what Richard Re calls "signaling"-taking official actions that do not establish conventional precedent or resolve ultimate merits issues, but nonetheless suggest, perhaps deliberately, how lower courts should decide cases. ${ }^{203}$ These unexplained stays and cert decisions played a significant role in the marriage equality litigation. At various points over the two years from Windsor to Obergefell, the Court stayed or declined to stay lower court decisions, unexpectedly denied cert in some cases, and unsurprisingly granted cert in other cases, all without explanation and often without apparent dissent. At the same time, lower courts appeared conflicted about what to do with the penumbras emanating from the shadow docket-whether to decide cases by exercising their best judgment applying the traditional four factors in light of existing precedent or to be guided by the Court's non-precedential and unexplained signals.

The third and related theme revolves around the centrality of the Supreme Court in constitutional litigation. The Justices have taken it upon themselves to resolve a significant constitutional issue, especially when it divides lower courts. This was especially true for the same-sex marriage cases. The existence of identical laws in so many states functionally created a nearly nationwide prohibition on same-sex marriage. Resolving the constitutional validity of this policy forms the core of the Court's role of judicial review. Given that inevitably, lower courts arguably were obligated to decide cases with

200. Baude, supra note 10, at 12-13 (quoting Maryland v. King, 133 S. Ct. 1, 3 (2012)

(Roberts, C.J., in chambers)).

201. Id. at 3 .

202. Id. at 5 .

203. Richard M. Re, Supreme Court Signals, PRAwFSBLAwG (Nov. 12, 2014), http:// prawfsblawg.blogs.com/prawfsblawg/2014/11/supreme-court-signals.html. 
an eye to minimizing issues that might complicate or hamper the Court's ultimate review. For example, district judges should have recognized that thousands of marriages could be invalidated if the Supreme Court were to ultimately uphold the bans. This should have influenced what courts did to define and maintain the status quo pending completion of litigation.

The Court exercised a high degree of control over when and how it would decide the issue through a series of unexplained stay orders and certiorari denials. It also attempted to control the status quo and ensure that lower courts did not negatively affect its eventual review or otherwise move too fast on the issue, through its stay and certiorari decisions. The problem emerged that lower courts differed on the deference owed to that procedural control. And the Court arguably can be blamed for relying on its non-precedential orders that did not explain what it was doing or how lower courts should respond. The inferior courts were forced to read between the lines.

\section{B. Phase I: Utah: Christmastime, 2013}

The first phase of the marriage equality litigation began in-of all places-Utah, a state whose admission to the Union was contingent on restricting marriage to one man and one woman (stress on "one"). ${ }^{204}$ On December 20, 2013, Judge Robert J. Shelby of the District of Utah rendered the first post-Windsor decision invalidating the states same-sex marriage ban, and immediately enjoining its enforcement. Most significantly for our purposes, the court did not impose a stay or delay the judgment to offer time to appeal. The decision did not even address any of the stay factors. ${ }^{205}$ Worse, the judge issued the decision at 1:30 p.m. MST on the Friday before Christmas. That afternoon, the Salt Lake County Clerk began issuing marriage licenses to same-sex couples. ${ }^{206}$ In what CNN described as "joyful mayhem," hundreds of people lined up at the Clerk's office, as the office stayed open past 5 p.m. ${ }^{207}$

204. On July 16, 1894, Congress enacted the Enabling Act that paved the way for Utah's admission to the Union. Section 3 provided, "[t]hat polygamous or plural marriages are forever prohibited." Enabling Act, UTAH STATE ARCHIVES, http://archives .utah.gov/research/exhibits/Statehood/1894text.htm.

205. Kitchen v. Herbert, 961 F. Supp. 2d 1181, 1216 (D. Utah 2013).

206. Emergency Motion for Stay at 3, Kitchen v. Herbert, 755 F.3d 1193 (10th Cir. 2014), https://www.scribd.com/doc/272208444/13-12-20-Emergency-Motion-for-Stay.

207. Tom Watkins, In Utah, judge's ruling ignites same-sex marriage frenzy, CNN (Dec. 20, 2013), http://www.cnn.com/2013/12/20/justice/utah-same-sex-marriage-ruling/ind ex.html. 
In a conference call with counsel several hours later, the district court declined to stay the order sua sponte or to entertain an oral motion to stay. ${ }^{208}$ Instead, Judge Shelby insisted that Utah file a written motion and ordered full briefing on the issue. ${ }^{209}$ Unfortunately, a ruling following briefing would not be prompt enough to avoid the issuance of more licenses. The Salt Lake County Clerk was scheduled to open and resume issuing licenses to same-sex couples at 8 a.m. on Monday, ${ }^{210}$ one hour before Judge Shelby's scheduled hearing. ${ }^{211}$

Utah launched a two-pronged attack to preserve the status quo. First, on Friday evening, Utah filed a written motion with Judge Shelby for stay pending appeal. The Attorney General cited the Ninth Circuit's grant of a stay in Perry v. Schwarzenegger-the challenge to California's Prop 8 litigation-as demonstrating the need "to preserve the status quo pending appellate determination." ${ }^{212}$ In Perry, however, Judge Walker stayed his judgment only for six days, leaving it to the court of appeals to put the mandate on hold. ${ }^{213}$ The court of appeals did so four days later. ${ }^{214}$ The situation in Utah would not play out so neatly. Second, Utah filed an emergency motion with the Tenth Circuit to stay the injunction until Judge Shelby ruled on the pending motion to stay. ${ }^{215}$ The Attorney General explained that the district court would not rule before the Salt Lake County Clerk's office would reopen on Monday and the stay was necessary to give Judge Shelby time to make his decision.

On Sunday, December 22, Tenth Circuit Judges Holmes and Bacharach denied the state's emergency motion. The motions panel explained that the rules of appellate procedure only permit the court to stay a final judgment pending appeal. The court could not stay a

208. Emergency Motion for Stay, supra note 206, at 2-3.

209. Id. at 3 .

210. Id.

211. Kitchen v. Herbert, District Court Docket No. 95 (D. Utah. Dec. 21, 2013).

212. Defendants' Motion to Stay Pending Appeal, Kitchen v. Herbert, 916 F. Supp. 2d 1181 (D. Utah Dec. 20, 2013), https://www.scribd.com/doc/272209007/13-12-20-Defen dants-Motion-to-Stay-Pending-Appeal, citing Perry v. Brown, 671 F.3d 1052, 1070 (9th Cir. 2012), vacated and remanded by Hollingsworth v. Perry, 133 S. Ct. 2652 (2013).

213. Perry v. Schwarzenegger, 702 F. Supp. 2d 1132, 1135 (N.D. Cal. 2010).

214. Perry v. Schwarzenegger, No. 10-16696, 2010 WL 3212786, at *1 (9th Cir. Aug. 16, 2010).

215. Emergency Motion for Stay, supra note 206, at 3. 
judgment pending the district court's decision on a motion to stay. ${ }^{216}$ The denial was without prejudice, giving the state leave to file a proper motion for a stay pending appeal of a final judgment. Early Monday morning, Utah filed with the Tenth Circuit a new emergency motion for temporary resolution of stay motions, ${ }^{217}$ which Judges Holmes and Bacharach promptly denied. ${ }^{218}$ The court explained, again, that the court of appeals cannot stay a judgment pending district court resolution of a stay motion. ${ }^{219}$ Further, the court rejected the government's "anticipatory request" to stay the district court's order in the event of an adverse ruling (on the motion for stay) later that day. ${ }^{220}$

At 9 a.m. that day, Judge Shelby held a hearing on the government's motion for stay pending appeal. At the end of the hearing, he denied from the bench the written motion he had requested, then issued a seven-page order later in the day. ${ }^{221}$ Judge Shelby offered four reasons for denying the stay. First, the state had not submitted evidence showing a likelihood of success on appeal. ${ }^{222}$ Second, Utah would suffer no harm by allowing same-sex couples to marry while the appeal was pending. The "court only consider[ed] the harm done to the State and not to the same-sex couples whose marriage arrangements may be subject to legal challenge."223 Third, the court concluded that some of the couples "may be facing serious illness or other issues that do not allow them the luxury of waiting for such a delay." 224 Finally, the public interest "weigh[ed] in favor of protecting the constitutional rights of Utah's citizens" to same-sex marriage. ${ }^{225}$ Judge Shelby even rejected a request for a stay to allow the Tenth Circuit to decide whether a stay is appropriate, insisting that doing so would not maintain the status quo.

Part of the problem with Judge Shelby's reasoning was a strange understanding of the status quo. On Friday morning, the status quo

216. Kitchen v. Herbert, No. 13-4178 (10th Cir. Dec. 22, 2013) (order denying stay), https://www.scribd.com/doc/273884289/13-12-22-Order-Denying-Motion-to-Stay.

217. Emergency Motion for Stay, supra note 206.

218. Kitchen v. Herbert, No. 13-4178 (10th Cir. Dec. 23, 2013) (order denying stay), https://www.scribd.com/doc/272300692/13-12-23-Order-Denying-Renewed-Motion.

219. Id.

220. Id.

221. Kitchen v. Herbert, No. 13-4178 (D. Utah Dec. 23, 2013) (order denying stay), https://www.scribd.com/doc/272300792/13-12-23-District-Courts-Order-on-Motion-to-Stay.

222. Id. at 3 .

223. Id. at 5 .

224. Id.

225. Id. at 6 . 
was what it had been for a century-Utah would not issue marriage licenses to same-sex couples. Judge Shelby's order, without a stay, immediately and perhaps irreparably altered the status quo. It now became the new normal that same-sex couples were allowed to marry, as the Clerk of Salt Lake County recognized. ${ }^{226}$ Thus, Judge Shelby reasoned, a stay would amount to an injunction preventing county clerks from issuing marriage licenses to same-sex couples. In other words, an alteration of the status quo. But this misunderstands the nature of injunctions and stays and their respective effects on the status quo. The stay would alter the status quo on Monday only because the court had already altered the status quo on Friday with its injunction. The point of a stay would be to suspend that alteration. ${ }^{227}$ Had Judge Shelby issued the stay on Friday, the practical status quo would have remained unchanged. Even if Judge Shelby was correct in anticipating how the Supreme Court would ultimately rule, at the time the decision wreaked of hubris. Michael Dorf argued that Shelby's decision not to stay the judgment reflected both the "correct moral outcome" and the "correct legal outcome," but was "still wrong," because "only a fool can confidently predict exactly what the Supreme Court will do in this case.",228

Shortly after the district court denied the stay on Monday, Utah filed two emergency motions in the court of appeals for a stay pending appeal and stay pending resolution of the motion to stay; Judges Holmes and Bacharach promptly denied both the following day. They insisted that Utah was not likely to succeed on appeal and there was not a strong threat of irreparable harm absent a stay. ${ }^{229}$

Utah then waited a full week before petitioning the Supreme Court for a stay pending appeal on New Year's Eve. ${ }^{230}$ Justice Sotomayor, as Tenth Circuit Justice, called for a response by January 3,2014 , although she did not issue a stay on her own initiative. ${ }^{231}$

226. Id

227. Nken v. Holder, 129 S. Ct. 1749, 1758 (2009).

228. Michael Dorf, Was Tenth Circuit Correct Not to Stay The District Court SSM Ruling?, DORF ON LAw, (Dec. 24, 2013), http://www.dorfonlaw.org/2013/12/was-10thcircuit-correct-not-to-stay.html.

229. Herbert v. Kitchen, No. 2:13-CV-00217-RJS (10th Cir. Dec. 24, 2013) (order denying emergency motion for stay and temporary motion for stay), https://www.scribd. com/ doc/272301500/13-12-24-Order-Denying-Emer-Motion-for-Stay.

230. Herbert v. Kitchen Docket, Supreme Court Docket No. 13A687, http://www.sup remecourt.gov/search.aspx?filename=/docketfiles/13a687.htm.

231. In contrast, also on New Year's Eve, Justice Sotomayor both called for a response and issued a stay against the enforcement of the Affordable Care Act's 
Under the Supreme Court's rules it takes five Justices to grant a stay. $^{232}$ On January 6, 2014, the full Court granted the stay, without comment or dissent. The meaning of that order would remain hotly contested in the lower courts for the next nine months.

Seventeen days after Judge Shelby's order, the judgment was finally stayed and same-sex marriages were put on hold. In the interim, Utah issued over 1,300 marriage licenses to same-sex couples, nearly 1,000 of which were solemnized. The recognition of these marriages would be subject to future litigation. ${ }^{233}$

Much of the blame for this disorder falls to Utah, which failed to request a stay of the judgment in advance, a point Judge Shelby emphasized in his order. ${ }^{234}$ Even if a stay might have been warranted, judges are not obligated to do so sua sponte. Utah, however, was not entirely at fault. It was likely unthinkable when summary judgment motions were filed following Windsor that the court would invalidate the law on the Friday before Christmas and let the judgment take effect immediately, particularly without performing a stay analysis. This was a mandatory injunction, requiring the state to take some action, making a stay especially appropriate. And being the first federal decision post-Windsor to invalidate a state ban should have counseled further caution. That Judge Shelby ultimately denied from the bench the written motion for a stay that he had requested, followed a few hours later by a seven-page opinion, makes it fairly apparent that he did not think a stay was warranted, whether or not the state requested it. Similarly, the Tenth Circuit promptly denied a stay pending appeal. In short, while Utah should be faulted for failing to request a stay in advance, the state would not have received the relief they ultimately requested.

contraceptive mandate against the Little Sisters of the Poor, see Little Sisters of the Poor v. Sebelius Docket, Supreme Court Docket No. 13A691, http://www.supremecourt.gov/ search.aspx?FileName=/docketfiles/13A691.htm.

232. Stephen R. McAllister, Practice Before the Supreme Court of the United States, J. KAN. B. Ass'N, April 1995, at 25, 37 ("It takes five votes to grant a stay, although it takes only four votes to grant a cert petition.").

233. Evans v. Utah, 21 F. Supp. 3d 1192, 1197 (D. Utah 2014). This was not the first time there was a race to the courthouse for same-sex marriage licenses. In 2004, dozens of gay and lesbian couples got married in New Mexico's Sandoval County in a single day, until the county clerk received orders from the attorney general to stop. The courts never decided whether the marriages were valid, so the couples remained legally married. At least one pair got divorced. So What Happens to the Same-Sex Marriage Licenses Issued in Utah, WSJ LAW BLOG (Jan. 6, 2014), http://blogs.wsj.com/law/2014/01/06/so-what-happens -to-the-same-sex-marriage-licenses-issued-in-utah/.

234. Kitchen v. Herbert, No. 2:13-cv-217 (D. Utah Dec. 23, 2013) (order denying motion to stay), https://www.scribd.com/doc/272208577/13-12-23-District-Courts-Order-on -Motion-to-Stay. 


\section{Phase II: Certiorari Pending: January-October 2014}

The lower courts divided over the significance of the Supreme Court's unexplained order in Kitchen. Some accepted it as a command to stay judgments until the full process played out through the courts of appeals and certiorari to the Supreme Court. Other courts did not get the same message and either distinguished or disregarded those orders. The overarching problem was the possible gap between the signal emanating from one (and eventually two more) unexplained Supreme Court orders and lower courts' analysis of the stay factors. Courts had to decide the weight to give that unexplained order in a case with identical consequences in the denial of the stay and to balance that against their independent equitable analysis.

District courts fell into three groups. One group stayed judgments until the appeals process was completed. A second group did not stay their judgments pending appeal, but did issue stays to give the court of appeals an opportunity to decide whether a stay was warranted. Finally, a third group, which also included the Fourth and Tenth Circuits, refused to stay their judgments at all, prompting the Supreme Court to intervene, as it had in Utah.

\section{Staying the Judgment}

Five district courts-the District of Oklahoma, ${ }^{235}$ Eastern District of Virginia, ${ }^{236}$ Western District of Texas, ${ }^{237}$ Southern District of Ohio, ${ }^{238}$ and Western District of Kentucky—got it right. Each declared inavlid bans on same-sex marriage, but put their judgments on hold pending the review process. They generally cited the Supreme Court's order in Kitchen.

Judge John G. Heyburn of the Western District of Kentucky's analysis was particularly measured. The Supreme Court "has sent a

235. Bishop v. U.S. ex rel. Holder, 962 F. Supp. 2d 1252, 1296 (N.D. Okla. 2014) ("[I]n accordance with the U.S. Supreme Court's issuance of a stay in a nearly identical case on appeal from the District Court of Utah to the Tenth Circuit Court of Appeals, see Herbert $v$. Kitchen ... the Court stays execution of this injunction pending the final disposition of any appeal to the Tenth Circuit Court of Appeals.").

236. Bostic v. Rainey, 970 F. Supp. 2d 456, 484 (E.D. Va. 2014).

237. De Leon v. Perry, 975 F. Supp. 2d 632, 666 (W.D. Tex. 2014) ("In accordance with the Supreme Court's issuance of a stay in Herbert $v$. Kitchen ... and consistent with the reasoning provided in Bishop and Bostic, this Court stays execution of this preliminary injunction pending the final disposition of any appeal to the Fifth Circuit Court of Appeals.").

238. Henry v. Himes, No. 1:14-CV-129, 2014 WL 1512541, at*1 (S.D. Ohio Apr. 16, 2014). 
strong message by its unusual intervention and order in [Kitchen]. It cannot be easily ignored." 239 But he recognized the need to balance the interests of plaintiffs, who appeared to have won important constitutional rights, against the systemic interests in complete review without chaos:

Perhaps it is difficult for Plaintiffs to understand how rights won can be delayed. It is a truth that our judicial system can act with stunning quickness, as this Court has; and then with sometimes maddening slowness. One judge may decide a case, but ultimately others have a final say. It is the entire process, however, which gives our judicial system and our judges such high credibility and acceptance. This is the way of our Constitution. It is that belief which ultimately informs the Court's decision to grant a stay. It is best that these momentous changes occur upon full review, rather than risk premature implementation or confusing changes. That does not serve anyone well. $^{240}$

Those systemic interests, in terms of the broader public-interest, even overcame the apparent weakness of the state's constitutional arguments on the merits. Following Judge Heyburn's lead, Judge Timothy Black of the Southern District of Ohio found that the government was unlikely to prevail on appeal and would not be irreparably harmed. But on the chance that the government did succeed on appeal, the result could be "confusion, potential inequity, and high costs." 241 The public interest warranted a stay because "[p]remature celebration and confusion do not serve anyone's best interests. The federal appeals courts need to rule, as does the United States Supreme Court.",2

239. Bourke v. Beshear, 996 F. Supp. 2d 542, 558 (W.D. Ky.) rev'd sub nom. DeBoer v. Snyder, 772 F.3d 388 (6th Cir. 2014) cert. granted sub nom. Obergefell v. Hodges, 135 S. Ct. 1039 (2015) and cert. granted sub nom. Tanco v. Haslam, 135 S. Ct. 1040 (2015) and cert. granted, 135 S. Ct. 1040 (2015) and cert. granted sub nom. Bourke v. Beshear, 135 S. Ct. 1041 (2015) and rev'd sub nom. Obergefell v. Hodges, 135 S.Ct. 2584 (2015).

240. Bourke, 996 F. Supp. 2d at 558 (emphasis added).

241. Henry v. Himes, No. 1:14-CV-129, 2014 WL 1512541, at*1 (S.D. Ohio Apr. 16, 2014).

242. Id. 


\section{Stays to Permit Appeals}

Other judges stayed their judgments to allow the state to seek a stay from the courts of appeals. Notably, this was similar to the process that Judge Walker and the Ninth Circuit employed in Perry. ${ }^{243}$ While this approach gave states time to review the injunctions and avoided the immediate chaos of a race to the altar, it still occasioned a mad scramble to obtain a stay before the judgment went into effect. Such time-limited stays also created the risk that the court of appeals would not intervene in time.

\section{a. District of Idaho}

After invalidating Idaho's marriage ban, Chief Magistrate Judge Candy Wagahoof Dale of the District of Idaho denied the state's motion to stay pending appeal, but set her injunction to take effect less than 72 hours later. ${ }^{244}$ The state noticed its appeal that day, and two days later the Ninth Circuit temporarily stayed the judgment pending resolution of the stay motion. ${ }^{245}$ Five days after that, the court granted a stay pending the entire appeals process. ${ }^{246}$ It took the Ninth Circuit eight days to consider the weighty matter, far more than the three the district judge had initially allotted.

Notably, Ninth Circuit Judge Hurwitz concurred in the stay order, but stressed that he did so solely because the Supreme Court "has virtually instructed courts of appeals to grant stays in the circumstances before us today." 247 He insisted that he would have reached a different conclusion "[i]f we were writing on a cleaner state" and independently weighed the traditional four factors. He also rejected the state's irreparable harm argument, finding that "[a]ny harm resulting from the possible invalidity of marriage licenses issued pendente lite to same-sex couples would be primarily suffered by the plaintiffs, not the State."248 Again, however, the analysis turned on the public-interest element and here, even while

243. Perry v. Schwarzenegger, 704 F. Supp. 2d 921, 1004 (N.D. Cal. 2010).

244. Latta v. Otter, 19 F. Supp. 3d 1054, 1087 (D. Idaho) aff'd, 771 F.3d 456 (9th Cir. 2014) cert. denied, No. 14-765, 2015 WL 2473531 (U.S. June 30, 2015) and cert. denied sub nom. Idaho v. Latta, 135 S. Ct. 2931 (mem.) (2015).

245. Latta v. Otter, No. 14-35420 (9th Cir. May 15, 2014) (order granting temporary stay), https://www.scribd.com/doc/270977326/Latta-v-Otter-14-5-15-Temporary-Stay.

246. Id

247. Id.

248. Id 
disagreeing with the conclusion, Judge Hurwitz captured the import of the Kitchen order:

[A]lthough the Supreme Court's order in Herbert is not in the strictest sense precedential, it provides a clear message-the Court (without noted dissent) decided that district court injunctions against the application of laws forbidding same-sex unions should be stayed at the request of state authorities pending court of appeals review." 249

\section{b. District of Utah (again)}

In Evans v. Herbert, Judge Dale Kimball held that Utah must recognize those 1,300 marriage licenses issued during the seventeenday interregnum following initial invalidation of Utah's same-sex marriage ban in Kitchen $v$. Herbert. ${ }^{250}$ He then stayed the decision for twenty-one days (a much more reasonable time period) to allow the state to seek a stay from the Tenth Circuit. The state appealed eighteen days later and the Clerk of the Tenth Circuit temporarily stayed the injunction. ${ }^{251}$ Three weeks later, a divided panel issued a stay only to give the state time to seek a stay from the Supreme Court. $^{252}$

Judge Kelly dissented from that order, insisting that the mandate should be permanently stayed pending completion of review, "to allow for an orderly resolution of this controversy and one based upon the rule of law." ${ }^{, 53} \mathrm{He}$ argued that denying the stay "complements the chaos begun by the district court in Kitchen," where "the State was compelled to issue marriage licenses to hundreds of same-gender couples" before "the Supreme Court granted a stay." 254 The dissent highlighted the oddity of the situation: even though the Supreme Court stayed the decision in Kitchen, the court of appeals did not stay the resulting order in Evans. "The rule contended for by the Plaintiffs - that a federal district court may change the law regardless of appellate review and the State is stuck

249. $I d$.

250. Evans v. Utah, 21 F. Supp. 3d 1192, 1214 (D. Utah 2014).

251. Evans v. Herbert, No. 14-4060 (10th Cir. June 5, 2014) (order granting temporary stay), https://www.scribd.com/doc/270979850/Evans-v-Herbert-2014-06-05-Temporary-St ay.

252. Evans v. Herbert, 21 F. Supp. 3d at 1230 (Kelly, J., dissenting).

253. Id.

254. Id. 
with the result in perpetuity-simply cannot be the law. It would not only create chaos, but also undermine due process and fairness.",255 Further, "[i]t is disingenuous to contend that the State will suffer no harm if the matter is not stayed; undoing what is about to be done will be labyrinthine and has the very real possibility to moot important issues that deserve serious consideration." 256 Granting the "stay would simply maintain the status quo until this case-and the broader issue to ultimately be resolved in Kitchen-comes to a resolution via the normal legal process, including that currently unfolding in the Utah courts." ${ }^{257}$ Rather, the "State and its citizens, and respect for the law, are better served by obtaining complete, final judicial resolution of these issues." 258 The Supreme Court would agree with Judge Kelly, and once again promptly stayed the order, ${ }^{259}$ without recorded dissent. ${ }^{260}$

Evans reflected a pattern in the District of Utah and the Tenth Circuit. For the second time, the district court declined to stay its judgment, forcing Utah to seek an emergency stay from the Tenth Circuit. For the second time, the court of appeals declined to stay the

255. Id

256. $I d$.

257. Id.

258. Id.

259. Evans v. Herbert, No. 14A65 (U.S. July 18, 2014) (order granting stay pending appeal), http://www.supremecourt.gov/orders/courtorders/071814zr_d18e.pdf.

260. In an interview, Justice Ginsburg suggested that the lack of a dissent from denial of a stay does not indicate that an order was unanimous. See Justices Silent Over Execution Drug Secrecy, WASH. TIMES (Aug. 3, 2014), http://www.washingtontimes.com/n ews/2014/aug/3/justices-silent-over-execution-drug-secrecy/?page=all. Ginsburg further suggested that it might depend on institutional concerns; see also Baude, supra note 10, at 3. Consider what Ginsburg said about Justice Sotomayor's position on the grant of a stay in Little Sisters of the Poor v. Sebelius:

"NLJ: A day after the Hobby Lobby decision, the court, with three dissents, issued an injunction against the application of the contraceptive insurance requirement to Wheaton College, a religious institution. Wheaton had objected to getting an exemption via a selfcertifying letter stating its objections to the coverage. You assigned the Wheaton dissent to Justice Sotomayor as well and she wrote a blistering opinion.

GINSBURG: That may have been the same thing. She granted the stay in Little Sisters of the Poor [raising similar objections to the letter] because she was the Tenth Circuit justice. I think it was another case where she wanted to make clear what her view was. Besides, there was enough in my dissent in Hobby Lobby. I had said everything I wanted to say on that subject so it was appropriate for somebody else." http://nationallawjournal.com/ module/alm/app/nlj.do\#!/article/1701862687; see also Josh Blackman, Little Sisters of the Poor v. Sebelius, Ginsburg, J., dissent from granting of stay on behalf of Sotomayor, J., after the fact, JOSH BLACKMAN's BLOG (Aug. 22, 2014), http://joshblackman.com/blog/201 4/08/22/little-sisters-of-the-poor-v-sebelius-ginsburg-j-dissenting-from-granting-of-stay-onbehalf-of-sotomayor-j-after-the-fact/. 
judgment pending appeal, forcing Utah to seek an emergency stay from the Supreme Court. And for the second time, the Supreme Court promptly granted the stay. If the message was not clear after the Supreme Court's Kitchen order, it should have become abundantly clear after Evans. Lower courts should continue to stay all same-sex marriage rulings and must maintain the status quo ex ante pending appeal.

\section{c. District of Colorado}

Five days after the Supreme Court granted the stay in Evans, Judge Raymond Moore of the District of Colorado discussed the problem of conflicting authorities. On one hand, the Supreme Court's actions in Kitchen and Evans stood as "implied directives to issue stays in these matters." ${ }^{261}$ On the other hand, doing so arguably is contrary to accepted standards for when to stay judgments under the traditional four factors. ${ }^{262}$ On the third hand, Moore noted that the Tenth Circuit had twice ${ }^{263}$ reached the constitutional merits, invalidating marriage bans in Utah and Oklahoma and enjoining enforcement of those laws. These judgments made it "conceivable that any perceived 'directive' from the Supreme Court to let appellate courts consider this issue does not apply here." ${ }^{264}$ On the fourth hand, the Court had stayed the judgment in Evans only five days earlier. This decision was a "wild card in the analysis," and "it appear[ed] to the [district c] ourt that it may well be that a message is being sent by the Supreme Court." ${ }^{265}$

Yet Judge Moore insisted that he was unable to divine the meaning of the Supreme Court's two stays. "[T]his Court is not some modern day haruspex skilled in the art of divination. This Court cannot-and, more importantly, it will not-tell the people of Colorado that the access to this or any other fundamental right will be delayed because it 'thinks' or 'perceives' the subtle-or not so subtle-content of a message not directed to this case.",266

Unlike other courts, Judge Moore was unwilling to be bound by the Supreme Court's unexplained stay decisions. He also manifested

261. Burns v. Hickenlooper, No. 14-CV-01817-RM-KLM, 2014 WL 3634834, at *4 (D. Colo. July 23, 2014).

262. Id

263. Bishop v. Smith, 760 F.3d 1070 (10th Cir. 2014) (Oklahoma); Kitchen v. Herbert, 755 F.3d 1193 (10th Cir. 2014) (Utah).

264. Burns, 2014 WL 3634834 at *4.

265. Id. at $* 5$.

266. Id. 
a very different conception of the rule of law than Judge Kelly had proffered, concluding that the "rule of law demands more.... Defendants are not entitled to a stay order under the applicable rules. This is where this Court's analysis must end." ${ }^{267}$

Judge Moore recognized that the Tenth Circuit or the Supreme Court might issue a stay in this matter, so he stayed the injunction for one month. And, in fact, the Tenth Circuit did just that several weeks later, citing earlier stays and finding no reason to deviate from that approach in this case. ${ }^{268}$ In doing so, the court of appeals noted that the Supreme Court had granted a stay of a Fourth Circuit decision the day prior. ${ }^{269}$

\section{d. Northern District of Florida}

In August, Judge Robert Hinkle of the Northern District of Florida declared that state's ban unconstitutional. Echoing the District of Colorado, Judge Hinkle explained that "it is a rare case in which a preliminary injunction is properly stayed pending appeal. ${ }^{270}$ But "[t]his is the rare case." presented an additional public-interest consideration. "There is a substantial public interest in implementing this decision just once-in not having, as some states have had, a decision that is on-again, offagain." ${ }^{272}$ Beyond the tumult an immediate order causes the state, the court observed that there is a possible harm to the couples deciding whether to marry. "[A]llowing those who would enter same-sex marriages the same opportunity for due deliberation that oppositesex couples routinely are afforded. Encouraging a rush to the marriage officiant, in an effort to get in before an appellate court enters a stay, serves the interests of nobody." 273 A stay was appropriate, although only "long enough to provide reasonable assurance that the opportunity for same-sex marriages in Florida, once opened, will not again close., ${ }^{274}$

267. Id

268. Burns v. Hickenlooper, No. 14-1283 (10th Cir. Aug 21, 2014) (order granting stay pending appeal), https://www.scribd.com/doc/270986446/BUrns-v-Hickenlooper-14-08-21Order-Granting-Stay.

269. Id.; see infra Part I.B.4.

270. Brenner v. Scott, No. 4:14CV107-RH/CAS (N.D. Fla. Jan. 1, 2015) (order clarifying preliminary injunction).

271. Id.

272. Id.

273. Id

274. Id 
Judge Hinkle stayed the injunction until Supreme-Courtimposed stays pending petitions for certiorari from the Fourth and Tenth Circuits were lifted, plus an additional ninety days. On December 3, 2014, following the denial of certiorari in those cases, ${ }^{275}$ an Eleventh Circuit panel ordered that the stay on Judge Hinkle's preliminary injunction would expire at the end of the day on January $5,2015 .^{276}$ By that point, petitions for certiorari had already been filed from decisions of the Sixth Circuit upholding same-sex marriage bans. Florida then sought an emergency stay from the Supreme Court on December 15, which the Court denied. Justices Scalia and Thomas dissented and would have granted the stay. ${ }^{277}$ On January 1, 2015 (four days shy of 90), the stay was lifted and the preliminary injunction went into effect, even while a cert grant from the Sixth Circuit was both inevitable and imminent ${ }^{278}$ and would be granted only eleven days later.

\section{Stays Denied}

The third category, and where things got ugly, involved judges who did not issue stays at all, even in light of the signals from Kitchen and Evans. District courts in four states ordered that same-sex marriage licenses must be issued or recognized before a higher court could intervene. Although in each case a higher court did issue a stay after only a quick appeal, it was not soon enough to prevent a repeat of the events in Utah. Hundreds of couples received marriage licenses pendent lite, creating a new potential group of injured plaintiffs should those injunctions be reversed.

\section{a. Western District of Tennessee}

Judge Aleta A. Trauger of the Middle District of Tennesse believed she had identified one distinction with the prior stay cases. Tanco v. Haslem was a recognition case, in which the court ordered the state to recognize three out-of-state same-sex marriages. ${ }^{279}$ But

275. See infra Part I.C.

276. Brenner v. Armstrong, No. 14-14061 (11th Cir. Dec. 3, 2014) (order denying motion to extend stay of preliminary injunction), https://www.scribd.com/doc/270989229/ Brenner-v-Scott-14-12-03-Order-Motion-to-Stay.

277. Armstrong v. Brenner Docket, Supreme Court Docket No. 14A650 (Dec. 19, 2014), http://www.supremecourt.gov/search.aspx?filename=/docketfiles/14a650.htm.

278. The petition in Obergefell would be distributed only four days later on December 23, 2014. See Obergefell v. Hodges Docket, Supreme Court Docket No. 14-556, http://ww w.supremecourt.gov/search.aspx?filename=/docketfiles/14-556.htm

279. Jesty v. Haslam, No. 3:13-CV-01159, 2014 WL 1117069, at*4 (M.D. Tenn. Mar. 20, 2014). 
the decision said nothing about whether the state had to issue marriage licenses to anyone. Thus, comparing this case to Bostic, DeLeon, and Bishop was "comparing apples and oranges." 280 Her order would "not open the floodgates for same-sex couples to marry in Tennessee, nor does it require Tennessee to recognize all legal same-sex marriages performed outside of Tennessee." ${ }^{281}$ Nevertheless, the Sixth Circuit promptly stayed the decision pending full review by a merits panel, emphasizing that "[b]ecause the law in this area is so unsettled, in our judgment the public interest and the interests of the parties would be best served by this Court imposing a stay on the district court's order until this case is reviewed on appeal." 282 Four months later the Supreme Court stay in Evans signaled that even recognition cases should be put on hold. ${ }^{28}$

\section{b. Eastern District of Michigan}

In March 2014, following a two-week trial and a month of consideration, Judge Bernard Friedman of the Eastern District of Michigan invalidated Michigan's ban and enjoined the state from enforcing it. ${ }^{284}$ But he did not issue a stay. He did not even analyze Kitchen or any other decision in which other courts had granted stays. And, as in Utah, the decision triggered a race to the altar. Approximately 300 couples obtained licenses in a twenty-four-hour period, all seemingly knowing that a stay of the order was imminent. ${ }^{285}$ As in Utah, United States Attorney General Eric Holder announced that these couples could seek federal benefits without awaiting final judicial resolution. ${ }^{286}$

The following day, a Saturday morning, the Sixth Circuit ordered the plaintiffs to respond to the state's emergency motion for a stay

280. Id. at $* 3$.

281. Id. at $* 4$.

282. Id. citing Henry v. Himes, No. 1:14-CV-129, 2014 WL 1512541 (S.D. Ohio Apr. 16, 2014).

283. Herbert v. Evans Docket, Supreme Court Docket No. 14A54, http://www.sup remecourt.gov/search.aspx?filename=/docketfiles/14a65.htm; see also supra notes 250-60 and accompanying text.

284. DeBoer v. Snyder, 973 F. Supp. 2d 757, 775 (E.D. Mich. 2014).

285. John Eligon \& Erik Eckholm, Gay Couples in Michigan Seize Their Chance to Be Married After Ruling, N.Y. TIMES (Mar. 23, 2014), http://www.nytimes.com/2014/ 03/23/us/gay-couples-in-michigan-seize-their-chance-to-be-married-after-ruling.html.

286. Statement of Attorney General Eric Holder on Federal Recognition of Same-Sex Marriages in Michigan, U.S. DEP'T OF JUSTICE (Mar. 28, 2014), http://www.justice.gov/ opa/pr/statement-attorney-general-eric-holder-federal-recognition-same-sex-marriagesmichigan. 
pending review, thereby temporarily putting the injunction on hold. ${ }^{287}$ Three days later, a divided panel granted the stay, finding that there was no basis to distinguish Kitchen (and three other cases which we address infra), which granted stays, and no reason to balance the equities any differently. ${ }^{28}$ Judge Helene White dissented from the stay order, insisting that, although the Court stayed the injunction in Kitchen, "it did so without a statement of reasons, and therefore the order provides little guidance." 289 In other words, the shadow docket was not precedential.

In January 2015, Judge Mark Goldsmith of the Eastern District of Michigan ruled that the state was required to recognize the 300 marriages performed in the twenty-four hours between the injunction and the Sixth Circuit stay. ${ }^{290}$ He stayed his judgment for twenty-one days to allow for review, but the state, already defending its ban before the Supreme Court, did not appeal. ${ }^{291}$

\section{c. Western District of Wisconsin}

After the tumult in Utah, the most chaotic marriage equality appeal arose in Wisconsin. Through a combination of inexplicable foot-dragging by the court and premature exuberance by state officials, eight days elapsed before marriages were put on hold.

On Friday, June 6, 2014, Judge Barbara Crabb of the Western District of Wisconsin declared that state's ban unconstitutional, but did not issue an injunction. ${ }^{292}$ In all other cases, the injunction accompanied the declaratory judgment in a single order. Instead,

287. DeBoer v. Snyder, No. 14-01341 (6th Cir. Mar. 22, 2014) (order directing plaintiffs to file a response), https://www.scribd.com/doc/270993091/DeBoaer-v-Snyder-1403-22-Order-From-Sixth-Circuit.

288. DeBoer v. Snyder, 14-01341 (6th Cir. Mar. 25, 2014) (order granting stay), https://www.scribd.com/doc/270993306/DeBoer-v-Snyder-14-3-25-ORder-Granting-Stay. Typically, a stay request can be made to the court of appeals only if relief were sought from the district court but the district court failed to afford the requested relief. FED. R. APP. P. 8(a)(2)(A)(ii). The Sixth Circuit found those requirements had been "substantially met" when the district court failed to rule on the stay request.

289. Id.

290. Caspar v. Snyder, 2015 WL 224741, 4:14-cv-11499 (E.D. Mich. Jan. 15, 2015).

291. Gov. Rick Snyder: State will not appeal court decision on 300 same-sex couples married in March, MiCHIGAN.GOV (Feb. 4, 2015), http://www.michigan.gov/snyder/0,4668, 7-277-57577_57657-346819-,00.html. This decision not to appeal speaks to the near impossibility of voiding marriages that were lawfully performed, and that society had come to rely on. See supra note 199 and accompanying text.

292. Wolf v. Walker, 986 F. Supp. 2d 982, 1028 (W.D. Wis. June 6, 2014), judgment entered (June 13, 2014), aff'd sub nom. Baskin v. Bogan, 766 F.3d 648 (7th Cir. 2014) cert. denied, 135 S. Ct. 316 (2014) and cert. denied sub nom. Walker v. Wolf, 135 S. Ct. 316 (2014). 
Judge Crabb gave the parties ten days to file supplemental materials concerning the state's motion to stay the injunction and requested proposed language for the injunction. It is not clear what additional materials could have been filed, as the issue had been briefed a month earlier. ${ }^{293}$ No other court made a similar request.

Declining to wait for an injunction, a number of clerks celebrated early. Dane County Clerk Scott McDonnel announced on Friday that "[ $t]$ he law right now is that the marriage ban is unconstitutional. If someone comes in and says, 'Can you marry me?' I have to follow the federal court." 294 This was wrong, of course, as the court had not issued an injunction, but merely declared the law unconstitutional. McDonnel was under no legal obligation to follow the declaration, although under he could find it persuasive and follow it. ${ }^{295}$ As in Utah and Michigan, the decision triggered a race to the altar-over the next eight days, more than 500 same-sex couples were issued licenses in nearly seventy counties across the state. ${ }^{296}$

On Friday evening, Wisconsin filed an emergency motion for a stay with the district court. ${ }^{297}$ The court took no action during the weekend, even as hundreds of marriage licenses were being issued. Rather, Judge Crabb scheduled a telephone hearing for 1 p.m. Monday, June 9, 2014. Before the hearing was held, and while the emergency motion for a stay was pending, Wisconsin filed an emergency motion for a stay with the Seventh Circuit. ${ }^{298}$

293. On May 23, 2014, Michigan filed a motion to stay to "preserve the status quo for when an appeal is filed." See Motion to Stay, Wolf v. Walker, 986 F. Supp. 2d 982 (W.D. Wis. June 6, 2014) (No. 14-cv-64-bbc), (https://www.scribd.com/doc/271037666/Wolf-vWalker-14-05-23-Motion-to-Stay.

294. Weddings Continue after Judge Declares Ban Unconstitutional, WIS. ST. J. (June 7, 2014), http://host.madison.com/news/local/weddings-continue-after-judge-declares-banunconstitutional/article_100865d0-c06e-5254-8cee-0d4733f17942.html\#ixzz3fPSnQjLe.

295. Steffel v. Thompson, 415 U.S. 452, 469-70 (1974 (quoting Perez v. Ledesma, 401 U.S. 82, 124-26 (opinion of Brennan, J.)); Samuel L. Bray, The Myth of the Mild Declaratory Judgment, 63 DUKE L.J. 1091, 1113 (2014).

296. Scott Walker \& J.B. Van Hollen Appeal Gay Marriage Ruling, MILWAUKEE WIS. J. SENTINEL (July 10, 2014), http://www.jsonline.com/news/statepolitics/scott-walker-jbvan-hollen-appeal-gay-marriage-ruling-b99308729z1-266644411.html. Litigation to establish the validity of those marriages never materialized and became moot when the Supreme Court denied cert in the case in October. See infra Part I.C.

297. Emergency Motion to Stay, Wolf v. Walker, 766 F.3d 648 (7th Cir. 2014) (Nos. 14-2386, 14-2387, 14-2388, 14-2525), https://www.scribd.com/doc/272305270/14-06-06Emer-Motion-to-Stay.

298. Emergency Motion for Temporary Stay from Relief, Wolf v. Walker, 766 F.3d 648 (7th Cir. 2014) (Nos. 14-2386, 14-2387, 14-2388, 14-2525), https://www.scribd.com/ doc/272305369/14-06-09-Appellants-ER-Motion-for-Temp-Stay-From-Relief. 
Following the Monday conference, the district court denied Wisconsin's motion for an emergency stay. ${ }^{299}$ First, in an interesting procedural wrinkle, Judge Crabb determined that she retained jurisdiction over the case, even though Wisconsin had already filed a notice of appeal that morning because "an appeal taken from an interlocutory decision does not prevent the district court from finishing its work and rendering a final decision." 300 Wisconsin thus made a similar mistake as Utah in seeking to stay an injunction that had not yet issued. This is impossible procedurally, even though clerks in the state were acting as if the injunction had been issued. This dynamic presented a serious catch-22 for states-they cannot stay an injunction that has not been issued, but the un-issued injunction is the reason they need to seek a stay.

Second, Judge Crabb concluded that the Supreme Court's stay orders were inapplicable, because this case was different-she had not issued an injunction yet and defendants did not cite any authority for the proposition that a court may stay a stand-alone declaratory judgment. ${ }^{301}$ On both fronts, Judge Crabb's decision to invalidate the law, but not issue an injunction, left Wisconsin in an interminable bind-they could not do anything until the coercive order issued.

Third, the Court brushed off any responsibility for clerks issuing marriage licenses, explaining that this was not a result of an injunction, which had not issued. She insisted that the propriety of clerks issuing these licenses in violation of state law was beyond the scope of the case..$^{302}$ To the extent that "defendants believe that a particular county clerk is issuing a marriage license in violation of

299. Wolf v. Walker, Nos. 14-2386, 14-2387, 14-2388, 14-2525 (7th Cir. June 9, 2014) (order denying emergency motion for stay), https://www.scribd.com/doc/271058059/Wolfv-Walker-14-06-09-Order-Denying-Emerngency-Motion-for-Stay.

300. Id. (quoting Wis. Mutual Ins. Co. v. United States, 441 F.3d 502, 504-05 (7th Cir. 2006)). The Seventh Circuit confirmed that conclusion in a two-page unsigned order issued on June 10, 2014, stating that "that the order appealed from may not be a final appealable judgment within the meaning of 28 U.S.C. $\S 1291$," because "[t]he district court has not entered a Rule 58 judgment in this case," as it "has yet to determine the specifics of the injunctive relief which it intends to enter." Wolf v. Walker, No. 14-2266 (7th Cir. June 10, 2014) (order denying emergency motion for stay), https://www.scribd.com/ doc/271058839/Wolf-v-Walker-14-06-10-Order-Stating-Case-Not-Appealable. However, without explanation, hours after issuing this unsigned order, in another unsigned order, "The court, on its own motion, VACATES the June 10, 2014 order as erroneously issued." Id.

301. Wolf v. Walker, No. 14-2266 (7th Cir. June 10, 2014) (order denying emergency motion for stay), https://www.scribd.com/doc/271058839/Wolf-v-Walker-14-06-10-OrderStating-Case-Not-Appealable.

302. Id. 
state law, that is an issue outside the scope of this case." ${ }^{303}$ The only viable option for Wisconsin would have been to initiate state court proceedings against the seventy clerks who were issuing licenses in violation of state law. ${ }^{304}$ This is formally correct, as the various clerks were not operating under the compulsion of a federal court injunction. ${ }^{305}$ Thus, they were not subject to the district court's control. But the court was almost certainly aware of the potential persuasive effect of her declaration on state officials and the foreseeable effect of delays in issuing (and staying) the injunction.

Eight days after the declaratory judgment, Judge Crabb entered, then immediately stayed, a preliminary injunction. ${ }^{306}$ While she would not have granted a stay as a matter of first impression, she could not ignore Kitchen or the other courts that had stayed injunctions in light of Kitchen. ${ }^{307}$ Finally reaching the conclusion she should have reached eight days earlier, Judge Crabb stated that although it was impossible to know why the Supreme Court had stayed Kitchen because it had not explained its action, every injunction since then had been stayed, at least where the state had requested one..$^{308}$

Given her ultimately correct resolution of the stay issue, it is difficult to fathom why Judge Crabb did not stay the judgment one week earlier, especially given the mischief that ensued in the gap between her declaration and the injunction. Blaming the clerks for acting prematurely and lawlessly is legally correct, but ignores the fact that Judge Crabb could have prevented the chaos by delaying her declaratory judgment until the injunction was ready. A cynical explanation may lie in Judge Crabb's opinion granting the stay:

After seeing the expressions of joy on the faces of so many newly wedded couples featured in media reports, I find it difficult to impose a stay on the event that is responsible for eliciting that emotion, even if

303. Id

304. In fact, three states would take that very step to prevent clerks from issuing licenses prior to an appellate decision. See infra Part III.A.

305. In any event, even had an injunction issued, most of these clerks were not parties to Wolf and thus would not have been bound by that injunction. In reality, most of the clerks would have been acting voluntarily, not under court compulsion, regardless of what orders Judge Crabb had issued. See infra Part II.

306. Wolf v. Walker, 26 F. Supp. 3d 866, 870 (W.D. Wis. 2014), appeal dismissed (June 16, 2014).

307. Id.

308. Id. 
the stay is only temporary. Same-sex couples have waited many years to receive equal treatment under the law, so it is understandable that they do not want to wait any longer. ${ }^{309}$

As a procedural matter, this is problematic. Judge Crabb knew from the outset that any injunction likely would be stayed in light of Kitchen. And she knew from watching other states what would happen on the ground in the absence of an express stay of the judgment. By delaying the injunction and stay for a week, she allowed the same race to the altar in Wisconsin. This race continued until she cut it off, preempting the inevitable Seventh Circuit stay. The most plausible explanation for this bizarre turn of events is that it was a deliberate effort to allow marriages to proceed before the court of appeals put them on hold, as it would have done following Kitchen.

\section{d. Southern District of Indiana}

In two decisions in spring 2014, Judge Richard Young of the Southern District of Indiana ordered the state to recognize one outof-state same-sex marriage and then declared the state's same-sex marriage ban unconstitutional in its entirety. ${ }^{310}$ He refused to stay either order. In the May 9 recognition order, he largely ignored decisions from courts staying injunctions, other than to insist that the narrow recognition order should not be controlled by Kitchen's concern for staying a broad injunction. ${ }^{311}$ (This was the same reasoning Judge Trauger had used in the Western District of Tennessee two months earlier; she was promptly reversed by the Sixth Circuit $^{312}$ ). But his second opinion, invalidating the ban on same-sex marriage licenses, did not cite any previous orders from any courts. $^{313}$

Unsurprisingly, given events in Utah, Michigan, and Wisconsin, clerks in Indiana immediately began issuing licenses to same-sex couples. An official from the Marion County Clerk's Office in

309. Id. at 874 .

310. Baskin v. Bogan, 983 F. Supp. 2d 1021, 1025 (S.D. Ind. 2014), appeal dismissed (July 14, 2014).

311. Id.

312. Supra Part II.C.3.a.

313. Baskin v. Bogan, 12 F. Supp. 3d 1144, 1149 (S.D. Ind.) aff'd, 766 F.3d 648 (7th Cir. 2014) cert. denied, 135 S. Ct. 316 (2014) and cert. denied sub nom. Walker v. Wolf, 135 S. Ct. 316 (2014). 
Indianapolis told the New York Times "[i]t's crazy busy." 314 Although the Seventh Circuit immediately stayed the injunction hours after Indiana submitted its application, and before a response was even filed, ${ }^{315}$ nearly a thousand same-sex couples, including 550 in Marion County, received licenses. ${ }^{316}$ As in Utah, Indiana Governor Mike Pence declined to recognize these "gap" marriages, insisting that the marriage law "is in full force and effect and executive branch agencies are to execute their functions as though the U.S. District Court Order of June 25, 2014 had not been issued." ${ }^{317}$ Without explanation, unlike in Utah and Michigan, the Department of Justice did not issue a statement that the federal government would recognize the Indiana gap marriages. ${ }^{318}$

\section{e. Fourth Circuit}

Demonstrating that the confusion over stays was not confined to the district courts, the Fourth Circuit offered the most inexplicable denial of a stay during the entire marriage equality litigation.

314. Jack Healy, U.S. Appeals Court Rejects Utah's Ban on Gay Marriage, N.Y. TIMES (June 26, 2014), http://www.nytimes.com/2014/06/26/us/us-appeals-court-rejects-utahs-banon-gay-marriage.html?_r=0.

315. Bogan v. Basin, No. 14-627 (7th Cir. June 27, 2014) (order granting stay), https://www.scribd.com/doc/271034362/Bogan-v-Baskin-14-6-27-Order-Granting-Stay.

Notably, Judges Posner, Williams, and Hamilton were on the motions panel for Bogan $v$. Baskin, and these judges also served as the merits panel for Baskin, which was consolidated with Wolf $v$. Walker. In contrast, in the Sixth Circuit none of the judges on the motions panel for DeBoer v. Snyder (Rogers, White, and District Judge Caldwell) were on the merits panel (Sutton, Cook, and Daughtry). Similarly, in the Eleventh Circuit, of the three judges on the motions panel (Kelly, Lucero, and Holmes), only Holmes was on the two-judge motion panel. For a discussion of how two Judges on the Seventh Circuit-Posner and Easterbrook-often retain merits appeals of cases they heard as motions judges, see Margaret v. Sachs, Superstar Judges as Entrepreneurs: The Untold Story of Fraud-On-The-Market, 48 U.C. DAVIS L. REV. 1207, 1237 (2015) ("If the motions panels had instead surrendered the appeals for reassignment to merits panels, the prevailing pattern in every other circuit, 180 some percentage of the merits panels would almost certainly not have included Judge Easterbrook or Judge Posner."). See generally, Alison Frankel, At 7th Circuit Unseen Judicial Mechanics Drive Decisions, REUTERS (Dec. 3, 2014), http://blogs.reuters.com/alison-frankel/2014/12/03/at-7th-circuit-unseen-judicialmechanics-drive-decisions-new-paper/.

316. State Recognizes June Marriages of Same-Sex Couples, USA TODAY (July 9, 2014), http://www.usatoday.com/story/news/politics/2014/07/09/state-recognize-june-marria ges-sex-couples/12410207/.

317. General Counsel to Gov. Mike Pence, Status of Same-Sex Marriages According to Indiana Law and Pursuant to Court Order (July 7, 2014), https://s3.amazonaws.com/s3.doc umentcloud.org/documents/1214271/status-of-same-sex-marriages-according-to.pdf.

318. Ian Thompson, What's the Holdup DOJ?, SlATE (Sept. 10, 2014, 9:00 AM), http://www.slate.com/blogs/outward/2014/09/10/married_same_sex_couples_in_indiana_an d_wisconsin_deserve_recognition.html. 
In July 2014, a divided panel affirmed a district court order declaring Virginia's same-sex marriage ban unconstitutional. Although the Supreme Court by that point had twice intervened and four sister circuits (Sixth, Seventh, Ninth, and Tenth) had stayed district court injunctions, the majority did not even address the issue. Accepting the stayed district court judgment as a permanent injunction, the court of appeals announced that the injunction would go into full effect once its mandate issued three weeks later. ${ }^{319}$ Twelve days after a motion for a stay pending the filing of a petition for certiorari, ${ }^{320}$ Judges Floyd and Gregory issued a brief, three-sentence order denying the motion. In what can be charitably described as deliberate indifference, the court order offered no citation or discussion of any of the orders from the Supreme Court or other circuits. $^{321}$ Because Virginia was no longer defending the law, a county clerk sought a stay from Supreme Court, faulting the Fourth Circuit for ruling without mentioning Kitchen and without engaging in any substantive analysis. ${ }^{322}$ As it had done in Kitchen and Evans, the Court promptly granted the stay without recorded dissent. ${ }^{323}$

And so ended the third epoch of same-sex marriage appeals, where the clear message was to stay judgment and mandates pending complete appellate review.

\section{Phase III: Certiorari Denied \& Circuit Splits: October 2014- January 2015}

The signal changed radically on the first day of the October 2014 term. The Court unexpectedly, and without published dissent, denied

319. FED. R. APP. P. 41(b) ("The court's mandate must issue 7 days after the time to file a petition for rehearing expires, or 7 days after entry of an order denying a timely petition for panel rehearing, petition for rehearing en banc, or motion for stay of mandate, whichever is later. The court may shorten or extend the time."). Opponents to Gay Marriage in Virginia Ask for Delay in Issuing Licenses to Couples, NBC WASH. (Aug. 14, 2014), http://www.nbcwashington.com/news/local/Virginia-Gay-Marriage-Fight-One-StepCloser-to-the-Supreme-Court-271091751.html.

320. Bostic v. Schaeffer, Motion for Stay of Mandate Pending Filing of Petition for Writ of Certiorari (4th Cir. Aug. 1, 2014), https://www.scribd.com/doc/271064286/Bostic14-08-01-Motion-by-Appellant-to-Stay-Mandate.

321. Bostic v. Schaeffer, No. 14-1167 (4th Cir. Aug. 13, 2014) (order denying motion to stay), https://www.scribd.com/doc/271064616/Bostic-14-08-13-4thDistCtOrderStayDenied 20140813-1.

322. McQuigg v. Bostic, Application to Stay Mandate Pending Appeal (Aug. 14, 2014), at $3 \mathrm{https} / /$ www.scribd.com/doc/236849402/McQuigg-Stay-Application.

323. McQuigg v. Bostic, No. 14A196 (Aug. 20, 2014) (order granting motion to stay pending appeal), http://www.supremecourt.gov/orders/courtorders/082014zr_i4dk.pdf. 
certiorari in the Bostic troika from the Fourth Circuit, ${ }^{324}$ Bogan and Wolf from the Seventh Circuit, ${ }^{325}$ and Bishop and Kitchen from the Tenth Circuit. ${ }^{326}$ This shocked ${ }^{327}$ Court watchers, who had been awaiting Court action on the marriage cases. ${ }^{328}$

The cert denials produced Article III-final judgments requiring officials in five states to issue marriage licenses to same-sex couples. They also spoke to the respective roles of the Supreme Court and lower courts in constitutional decision-making and to the Court's discretion as to when to exercise its jurisdiction. Two weeks earlier in remarks at the University of Minnesota Law School, Justice Ginsburg

324. McQuigg v. Bostic, 135 S. Ct. 314 (2014); Schaefer v. Bostic, 135 S. Ct. 308 (2014); Rainey v. Bostic, 135 S. Ct. 286 (2014).

325. Bogan v. Baskin, 135 S. Ct. 316 (2014); Walker v. Wolf, 135 S. Ct. 316 (2014).

326. Smith v. Bishop, 135 S. Ct. 271 (2014); Herbert v. Kitchen, 135 S. Ct. 265 (2014).

327. The cert denials were contained in an 89-page order list, which included the results of the September "Long Conference" in which the Court decides the thousands of cert petitions from the summer recess. See Linda Greenhouse, How Not To Be Chief Justice: The Apprenticeship Of William H. Rehnquist, 154 U. PA. L. REV. 1365, 1368 (2006).

The order list was posted to the Court's recently redesigned, but still buggy, web site. U.S. Supreme Court Technical Glitch, WBRZ, Oct. 6, 2014, http://www.wbrz.com/news/highcourt-glitch-delays-news-on-gay-marriage/. Marcia Coyle of the National Law Journal commented that: "A mad scramble ensued to search for the orders list on the Supreme Court's newly redesigned website. 'Where the [expletive] is the orders list?' came a frustrated shout from one end of the pressroom. 'Wait, wait, it's up now, shouted another." See Marcia Coyle, "Behind the Scenes: SCOTUS Media Room on Opening Day,” NAT'L L.J. (Oct. 6, 2014), http://www.nationallawjournal.com/legaltimes/ home/id $=1202672471618 ? \mathrm{kw}=$ Behind $\% 20$ the $\% 20$ Scenes $\% 3$ A $\% 20$ SCOTUS $\% 20$ Media $\%$ 20Room \%20on \%20Opening\%20Day\&et=editorial\&bu=National\%20Law\%20Journal\&c $\mathrm{n}=20141006 \& \mathrm{src}=$ EMC-Email\&pt=Legal \%20Times \%20Afternoon \%20Update\&slreturn $=20140906163648$.

328. Adding to the drama, the paper list distributed to the press by the Public Information Office was missing thirty-three pages, including the pages containing the seven cert. denials. As Coyle relayed the story: "Everyone looked at the bulky list first for any sign of the seven pending same-sex marriage petitions. Seeing none, reporters tweeted that the court had said nothing about same-sex marriage Monday. But as reporters, most on deadlines, continued to comb the list for other news, NBC's Pete Williams suddenly called out, 'The list goes from page 17 to 50.' Where were the missing 33 pages, and more importantly, what was on those pages?" Id. Garret Epps remarked that "a number of reporters went upstairs for oral argument, not knowing that history was being made. (I was one.)."

Supreme Court spokesperson Kathy Arberg blamed the problem on "technical glitches." Coyle added that the "high court's copy machine apparently had a bad morning, but perhaps not as bad as those editors and reporters who soon regretted those early advisories of no news on same-sex marriage." See Josh Blackman, SCOTUS Press Room Confusion - 33 Pages of Orders Missing Due to Technical Glitches, JOSH BLACKMAN BLOG (Oct. 6, 2014), http://joshblackman.com/blog/2014/10/06/scotus-press-room-confus ion-33-pages-of-orders-missing-due-to-technical-glitches/. 
hinted that "when all the courts of appeals are in agreement there is no need for us to rush to step in," 329 although "[s]ooner or later, yes, the question will come to the Court." ${ }^{330}$

The cert denials seemed inconsistent with the Court's signals in granting multiple stays over the previous eight months. As Baude argued, "one would have guessed that the stays were premised on the probability that the Court would take up the issue. So something unusual was going on, but we don't know what." 331

The cert denials shifted the analysis in three respects. First, it might have tempted lower courts to treat the denials as, if not a decision on the merits, a strong signal that the Court agreed with the decisions invalidating state laws. ${ }^{332}$ Second, it raised the possibility that the Court might leave the constitutional issue to the lower courts-at least, Justice Ginsburg suggested, so long as they all went the same way, as had been the case to that point. Third, it signaled that the Court was no longer concerned with preserving its opportunity to speak before the lower court judgments took effect or with states issuing marriage licenses to same-sex couples on the persuasion of lower court decisions. There was no practical difference in licenses issued on the strength of an Article-III final judgment as opposed to on the strength of an unstayed district court order-the result is marriage licenses issuing before the Supreme Court has spoken.

Although there was no dissent from the orders denying cert., Justice Thomas, joined by Justice Scalia, subsequently revealed his disagreement in a dissent from a denial of a stay in an unrelated case a month later. Citing Hollingsworth v. Perry (the Prop 8 case), Justice Thomas argued that, "we often review decisions striking down state laws, even in the absence of a disagreement among lower courts." ${ }^{333}$ Referring to the cert. denials in the same-sex marriage

329. Lyle Denniston, Mixed Signals on Same-Sex Marriage, SCOTUSBLOG (Sept. 18, 2014), http://www.scotusblog.com/2014/09/mixed-signals-on-same-sex-marriage/.

330. Id.

331. Baude, supra note 10, at 7-8.

332. But see Brown v. Allen, 344 U.S. 443, 456 (1953) ("We have frequently said that the denial of certiorari 'imports no expression of opinion upon the merits of a case.") (citations and internal quotation marks omitted).

333. Maricopa Cty., Arizona, et al., v. Angel Lopez-Valenzuela, 135 S. Ct. 428 (Nov. 13, 2014) (Thomas, J., dissenting from denial of application for stay) (citing Hollingsworth v. Perry, 133 S. Ct. 2652 (2013)). 
cases, however, "for reasons that escape me, we have not done so with any consistency, especially in recent months.",334

Lower courts reacted to this shift in signals almost immediately.

\section{Ninth Circuit}

Just over thirty hours after the cert denials, writing for a Ninth Circuit panel, Judge Stephen Reinhardt declared unconstitutional marriage bans in Idaho and Nevada. ${ }^{335}$ The court remanded the cases to the district courts for entry of permanent injunctions. Rather than waiting the typical seven days before issuing a mandate, ${ }^{336}$ the panel ordered its mandate to take effect that day.

The Nevada Governor and Attorney General announced that the state would take no further action in this matter. ${ }^{338}$ But Idaho launched a multi-pronged attack. On October 8 at 5:30 a.m. EDT, it filed an emergency motion with the Ninth Circuit to recall the

334. Id. Seven months later, the two Justices also dissented from denial of certiorari in Maricopa (as opposed to denying a stay), stating that "discretion [to review cases] should be exercised with a strong dose of respect for state laws. In exercising that discretion, we should show at least as much respect for state laws as we show for federal laws .... Our indifference to cases such as this one will only embolden the lower courts to reject state laws on questionable constitutional grounds." Maricopa Cty., $135 \mathrm{~S}$. Ct. at 2046.

335. The Idaho case was Latta v. Otter. The case from Nevada was Sevcik v. Sandoval. Sevcik is a unique case with a lengthy posture. In 2012, the district court found Nevada's marriage law constitutional, and it was appealed to the Ninth Circuit of December 4, 2012, six months before United States $v$. Windsor was decided. The case was stayed until July 18, 2013-after the decision in Windsor-and was not argued, along with Latta, until September 8, 2014.

336. FED. R. APP. PROC. 41.

337. Latta v. Otter, No. 14-35420 (9th Cir. Oct. 7, 2014) (order issuing mandate), https://www.scribd.com/doc/271297775/Latter-v-Otter-14-10-07-Mandate-Forthwith. As in Hollingsworth $v$. Perry, Judge Reinhardt (who was on both panels) did not wait twentyfive days for the mandate to issue before dissolving the stay.

338. Ninth Circuit Strikes Marriage Bans in Idaho and Nevada, WASH. BLADE (Oct. 7 , 2014), http://www.washingtonblade.com/2014/10/07/ninth-circuit-strikes-marriage-bansidaho-nevada/. At some point on Wednesday morning (exactly what time is unclear), Nevada District Court Judge Robert C. Jones, who had previously upheld Nevada's samesex marriage ban, recused rather than lift the stay and let gay marriages proceed in Nevada. No explanation was given for the recusal. Around 4:22 ET on Wednesday, the case was reassigned to Judge James Mahan. Chris Geidner, Conservative Nevada Juge Recuses Himself from Ending Marriage Ban, BuZZFEED (Oct. 8, 2014), http://www.buzzfeed.com/chrisgeidner/conservative-nevada-judge-recuses-himself-fromending-marria\#.hdlb9XJgGq. Sevcik v. Sandoval, No. 2:12-cv-00578-RCJ-PAL (D. Nev. Oct. 8, 2014) (recusal order), https://www.scribd.com/doc/271304203/Sevcik-v-Sandoval14-10-08-recuse. 
mandates. ${ }^{339}$ A few hours later, it filed an emergency application to stay the mandates with Circuit Justice Kennedy. The application explained that without a Supreme Court stay, marriage licenses would have to be issued to same-sex couples that day at $8 \mathrm{a} . \mathrm{m}$. MDT, or 10 a.m. EDT. ${ }^{340}$ At 9:47 a.m. EDT, ${ }^{341}$ with thirteen minutes to spare, Justice Kennedy stayed the mandate pending further orders and requested a response from the plaintiffs by October 9. ${ }^{342}$

But there was a problem with Justice Kennedy's order, perhaps caused by the haste with which the motion was filed. He ordered the recall of the mandate not only in the Idaho case, but also in the Nevada case, inadvertently putting on hold same-sex weddings there even though the state was no longer litigating the issue. ${ }^{343}$ The Clark County, Nevada, clerk tweeted at 11:30 a.m. EDT that the "issuance of marriage licenses to same-sex couples is on hold due to an order from the U.S. Supreme Ct." ${ }^{344}$ Reporter Lyle Denniston explained that the error was due to the fact that the caption on the Ninth Circuit order included both cases. ${ }^{345}$ Someone in Justice Kennedy's chambers likely copied and pasted the caption from the Ninth Circuit's order, even though only Idaho appealed.

Finally, at 3:18 p.m, Justice Kennedy issued a revised order, vacating the stay in the Nevada case. ${ }^{346}$ Same-sex marriages in Nevada proceeded, albeit delayed by five hours. The stay for the

339. Appellants' Emergency Motion for Recall of Mandate, Latta v. Otter, 771 F.3d 456 (9th Cir. Oct. 8, 2014) (Nos. 14-35420 \& 14-35421), https://www.scribd.com/ doc/271299136/Latter-v-Otter-14-10-08-Emergency-Recall-Mandate.

340. Emergency Application of Governor C L "Butch" Otter to Stay Mandate Pending Disposition of Applications for Stay Pending Rehearing And Certiorari, Latta v. Otter, 135 S. Ct. 344 (2014) (No. 14A374), https://www.scribd.com/doc/271299344/Latterv-Otter-Emergency-Stay-Motion-10-8-14.

341. Lyle Denniston, Idaho Same-Sex Marriage Delayed, SCOTUSBLoG (Oct. 8, 2014), http://www.scotusblog.com/2014/10/idaho-asks-same-sex-marriage-delay/.

342. Latta v. Otter, No. 14A374 (Oct. 8, 2024) (order granting stay), https://www. scribd.com/doc/271299469/Latter-v-otter-14-10-08-SCOTUS-Granting-Motion-to-Stay.

343. Chris Geidner, Justice Anthony Kennedy Halts 9th Circuit Marriage Ruling, BUZZFEED (Oct. 8, 2014), http://www.buzzfeed.com/chrisgeidner/justice-anthonykennedy-halts-9th-circuit-marriage-ruling-fr\#.gjokgAjXBZ

344. Id.

345. Lyle Denniston, Same-Sex Marriage OK in Nevada, SCOTUSBLOG (Oct. 8, 2014), http://www.scotusblog.com/2014/10/same-sex-marriages-in-nevada-maybe-yes-may be-no/. Fittingly, the original title of the post was "Same-Sex Marriage in NevadaMaybe Yes, Maybe No."

346. Latta v. Otter, No. 14A374 (Oct. 8, 2014) (revised order), https://www.scribd. com/doc/271300597/Latta-v-Otter-14-10-8-Revised-Order; see also Lyle Denniston, SameSex Marriage OK in Nevada, SCOTUSBLOG (Oct. 8, 2014), http://www.scotusblog .com/2014/10/same-sex-marriages-in-nevada-maybe-yes-maybe-no/. 
Idaho case remained in effect pending further orders from Justice Kennedy or the Court.

At 5:51 p.m. EDT, the Ninth Circuit issued an order "interpret[ing]" the Supreme Court's revised order "as a directive to recall the mandates" in the Idaho case ${ }^{347}$ which the court did. It is not clear why the court did this. Justice Kennedy's order had expressly requested a response from the plaintiffs as to the stay. It did not order or suggest that the court of appeals do anything, particularly withdrawing the mandate, which would moot the application before the Supreme Court. Ostensibly disregarding the Ninth Circuit's order, the Supreme Court late Friday afternoon denied the stay and vacated its previous order, without any noted dissent. ${ }^{348}$ This was the first denial of a stay by the Supreme Court, following on the heels of the cert denials four days earlier. According to one commenter, "courts likely will take this move as a sign that stays are no longer required during marriage appeals." ${ }^{349}$

On October 15, 2014, the same Ninth Circuit panel dissolved its original stay in Latta, ${ }^{350}$ which had remained in effect even after the Supreme Court's order. ${ }^{351}$ The per curiam opinion offered a helpful recitation of the turn of events and of the significance of the Court's denial of certiorari and denial of stay in Latta. ${ }^{352}$ It explained that the Ninth Circuit's stay was issued a number of months ago, before relevant factual and legal developments, including decisions invalidating marriage laws in Latta and in other circuits. Those decisions, in tandem with the cert denials, altered the calculus so that Idaho could no longer meet the standard for granting or continuing a

347. Latta v. Otter, No. 14-35420 (9th Cir. Oct. 8, 2014) (order recalling mandates), https://www.scribd.com/doc/271301173/Latta-v-Otter-10-8-14-Order-Recall.

348. Latta v. Otter, No. 14A374 (Oct. 10. 2014) (order denying motion to stay), https://www.scribd.com/doc/271301531/Latta-v-Otter-14-10-10-deny-stay.

349. Chris Geidner, Supreme Court Allows Idaho Same-Sex Marriages to Proceed, BUZZFEED (Oct. 10, 2014), http://www.buzzfeed.com/chrisgeidner/supreme-court-allowsidaho-same-sex-marriages-to-proceed-end\#.boaybr9Mdj.

350. Latta v. Otter, No. 14-35420 (9th Cir. May 15, 2014) (order granting temporary stay), https://www.scribd.com/doc/270977326/Latta-v-Otter-14-5-15-Temporary-Stay.

351. Latta v. Otter, No. 14-35420 (9th Cir. Oct. 15, 2014) (order and opinion dissolving stay), https://www.scribd.com/doc/271302160/Latta-v-Otter-14-10-15-Ca9-Another-Stay. Rather than seeking another emergency appeal to the Supreme Court, Idaho filed a petition for rehearing en banc before the Ninth Circuit. On January 9, 2015, the petition was denied over the dissents of Judges O'Scannlain, Rawlinson, and Bea. Ultimately, the Supreme Court denied certiorari on June 30, 2015. See Latta v. Otter, 135 S. Ct. 345 (2014).

352. Latta v. Otter, 771 F.3d 496, 498 (9th Cir. 2014). 
stay. Specifically, when the "Supreme Court denied certiorari in all the pending cases, it was aware that there were cases pending in other circuit courts that had not yet been decided but that might subsequently create a conflict. The existence of those pending cases, and the possibility of a future conflict, did not affect the Court's decision to permit the marriages to proceed." ${ }^{353}$ The cert denials signaled that the Justices were now content with same-sex marriage becoming the law within the regional circuit even while other petitions for certiorari remained outstanding.

Interestingly, in upholding the marriage laws in Kentucky, Michigan, Ohio, and Tennessee two months later, Judge Jeffrey Sutton of the Sixth Circuit drew the opposite lesson from the cert denials. ${ }^{354}$ He minimized the significance of the seven denials from among the 1,575 cases in the orders list that first Monday in October. He explained that "this kind of action (or inaction) "imports no expression of opinion upon the merits of the case, as the bar has been told many times." ${ }^{355}$ Sutton further argued that "[j]ust as the Court's three decisions to stay those same court of appeals decisions over the past year, all without a registered dissent, did not end the debate on this issue, so too the Court's decision to deny certiorari in all of these appeals, all without a registered dissent, does not end the debate either." ${ }^{356}$ In either direction, a decision not to decide is a decision not to decide.

A few loose ends remained in the Ninth Circuit. On October 12, 2014, Judge Timothy M. Burgess of the District of Alaska declared that state's marriage ban unconstitutional and immediately enjoined the state from enforcing it. ${ }^{357}$ Alaska appealed and the panel only granted a stay to give the state an opportunity to seek a stay from the Supreme Court. ${ }^{358}$ Curiously, Judge O'Scannlain would have granted the stay pending the entire appeals process. ${ }^{359}$ His dissent relied on the Kitchen stay order, but disregarded that fact that the Court had denied certiorari in that case a few days earlier and had signaled in

353. Id. at 499.

354. DeBoer v. Snyder, 772 F.3d 388 (6th Cir. 2014).

355. Id. at 402 (citing United States v. Carver, 260 U.S. 482, 490 (1923)). "The 'variety of considerations [that] underlie denials of the writ' counsels against according denials of certiorari any precedential value." Teague v. Lane, 489 U.S. 288, 296 (1989) (internal citation omitted).

356. Id.

357. Hamby v. Parnell, 56 F. Supp. 3d 1056, 1073 (D. Alaska 2014).

358. Hamby v. Parnell, No. 14-35856 (9th Cir. Oct. 15, 2014) (order granting stay), https://www.scribd.com/doc/272313595/14-10-15-Order-Granting-Stay.

359. Id. 
Latta that it would not grant further stays. For O'Scannlain, the weight of the stay trumped the weight of the cert denial. As would become the new normal, the Supreme Court denied Alaska's emergency motion for a stay, without noted dissent. ${ }^{360}$

On October 17, 2014, Judge John Sedwick immediately enjoined Arizona's marriage ban in light of Ninth Circuit precedent, complaining that "it is clear... that the High Court will turn a deaf ear on any request for relief from the Ninth Circuit's decision.. ${ }^{361}$ In a testament to how quickly things had changed with respect to the same-sex marriage appeals, that same day Arizona Attorney General Tom Horne - a lame duck who had lost the Republican primary-did not seek a stay, claiming that such a frivolous appeal would warrant Rule 11 sanctions:

The probability of persuading the 9th Circuit to reverse today's decision is zero. The probability of the United States Supreme Court accepting review of the 9th circuit decision is also zero. I have decided not to appeal today's decision, which would be an exercise in futility, and which would serve only the purpose of wasting taxpayers' money. ${ }^{362}$

Horne was correct about the practical futility and the desirability of not wasting taxpayer money, although his Rule 11 argument is overstated.

\section{Fourth and Seventh Circuits}

While chaos reigned in the Ninth Circuit, matters were much more orderly in the Fourth and Seventh Circuits. By denying certiorari, the Supreme Court created Article III-final judgments in both circuits and both courts of appeals lifted stays of their mandates, ${ }^{363}$ causing the injunctions to take effect. ${ }^{364}$ Same-sex

360. Hamby v. Parnell, No. 14A413 (Oct. 18, 2014) (order denying stay), https://www. scribd.com/doc/272313694/14-10-18-deny-stay.

361. Majors v. Horne, 14 F. Supp. 3d 1313, 1315 (D. Ariz. 2014)

362. Arizona Attorney General Press Release, Attorney General Tom Horne Will Not Appeal Same-Sex Marriage Ruling (Oct. 17, 2014), https://www.azag.gov/pressrelease/attorney-general-tom-horne-will-not-appeal-same-sex-marriage-ruling.

363. While a mandate issues twenty-five days after the judgment, "if the petition is denied, the mandate issues forthwith.” SUP. CT. R. 45. 
marriages began almost immediately in the affected states of Virginia, Wisconsin, and Indiana. ${ }^{365}$

Federal district courts in North Carolina, where litigation was pending but not yet appealed, lifted their own stays. ${ }^{366}$ Officials in South Carolina began issuing licenses without awaiting an order declaring invalid that state's law. ${ }^{367}$ The Fourth Circuit denied a request by the South Carolina Attorney General for a stay and any additional time to seek a stay from the Supreme Court. ${ }^{368}$ The high court denied that stay, over dissents of Justices Scalia and Thomas. ${ }^{369}$

\section{Tenth Circuit}

Following the cert denials, the Tenth Circuit similarly lifted stays in cases from Utah, Oklahoma, and Colorado, immediately putting into effect the preliminary injunctions that were previously stayed. ${ }^{37}$ Nevertheless, district courts within the circuit—now bound by circuit precedent to declare state laws unconstitutional—still exercised some

364. Bostic v. Schaeffer, No. 14-1167 (L) (4th Cir. Oct. 6, 2014) (mandate), https://www.scribd.com/doc/271071787/Bostic-14-10-6-mandate; Wolf v. Walker, No. 142525 (7th Cir. Oct. 7, 2014) (order affirming district court), https://www.scribd.com/doc/ 271071351/Wolf-14-10-07-AFFIRMING-District-Court; Baskin v. Bogan, No. 14-2386 (7th Cir. Oct. 7, 2014) (mandate), https://www.scribd.com/doc/271071539/Baskin-14-10-7-order.

365. President Obama said of the cert denials: "In some ways, the decision that was just handed down to not do anything about what states are doing on same-sex marriage may end up being as consequential - from my perspective, a positive sense-as anything that's been done." Jeffrey Toobin, How Obama Transformed the Federal Judiciary, THE NEW YORKER (Oct. 27, 2014), http://www.newyorker.com/magazine/2014/10/27/obamabrief.

366. Fisher-Borne v. Smith, No. 1:12-cv-589 (M.D.N.C. Oct. 8, 2014) (order lifting stay), https://www.scribd.com/doc/271073702/NC-14-10-08-Order-Lifting-Stay; Bradacs v. Haley, No. 3:13-cv-02351-JMC (D.S.C. Oct. 7, 2014), https://www.scribd.com/doc/ 271074754/SC-14-10-07-Order-Lifting-Stay; McGee v. Cole, No. 3:13-24068 (S.D. W. Va. Oct. 7, 2014) (order lifting stay), https://www.scribd.com/doc/271073868/Wv-Stay-LiftedOct-7.

367. Condon v. Haley, 21 F. Supp. 3d 572, 580 (D.S.C. 2014).

368. Emergency Application to Stay U.S. Dist. Court Order, Condon v. Haley, 135 S. Ct. 702 (2014) (No. 14A533), http://sblog.s3.amazonaws.com/wp-content/uploads/2014 /11/14A533_Stay_Application.pdf.

369. Wilson v. Condon, 135 S. Ct. 702 (2014).

370. Herbert v. Kitchen, No. 13-4178 (10th Cir. Oct. 6, 2014) (order lifting stay), https://www.scribd.com/doc/271071169/Kitchen-Herbert-14-10-6-order; Bishop v. Smith, Nos. 14-5003 \& 14-5006 (10th Cir. Oct. 6, 2014) (order lifting stay), https://www.scribd .com/doc/271071207/Bishop-Oklahoma-14-10-06-Order. Burns v. Hickenlooper, No. 141283 (10th Cir. Oct. 6, 2014), https://www.scribd.com/doc/ 271074943/Hickenlooper-14-1007-Order. Judge Raymond P. Moore of "haruspex" fame entered a permanent injunction ten days later on 10/17/14. Burns v. Hickenlooper, No. 14-cv-01817-RM-KLM (D. Co. Oct. 17, 2014) (order granting unopposed motion), https://www.scribd.com/doc/2723 14979/14-10-17-Order-Granting-Unopposed-Motion. 
caution. In Wyoming, Judge Scott W. Skavdahl stayed the injunction for six days to give the state a chance to appeal, which it declined to do. ${ }^{371}$

The situation was more complicated in Kansas. Judge Daniel D. Crabtree granted a one-week stay as the "safer and wiser course" to give the state time to prepare to honor the injunction. ${ }^{372}$ After the Tenth Circuit refused to stay the case, Kansas sought a stay from the Supreme Court. ${ }^{373}$ Circuit Justice Sotomayor stayed the order to await a response ${ }^{374}$ but the full Court denied the stay two days later. ${ }^{375}$

Perhaps signaling another shift, Justices Scalia and Thomas would have granted the stay. This was the first time since the cert denials that any Justices registered a dissent on the marriage appeals. $^{376}$ (A dissent from the South Carolina case ${ }^{377}$ would come two weeks later). What changed? On November 6, 2014, the Sixth Circuit became the first (and ultimately only) court of appeals to declare that same-sex marriage bans did not violate the Constitution. This created a circuit split, virtually ensuring the Court would grant certiorari and resolve the constitutional issue that term. Justices Scalia and Thomas apparently believed all other cases should be placed on hold pending the Court's resolution by the following July. Once there was a circuit split, they dissented from the denial of every subsequent stay application.

It is worth considering how positions on stays shifted following the cert denials. It takes five votes to grant a stay, meaning at least five Justices had previously voted for the stays in Kitchen, Evans, and Bostic. Given that Scalia and Thomas continued to want to stay judgments, at least three Justices who previously voted for stays must have changed positions. The other two dissenters in ObergefellRoberts and Alito-never registered any disagreement with respect

371. Guzzo v. Mead, No. 14-CV-200-SWS, 2014 WL 5317797, at*9 (D. Wyo. Oct. 17, 2014).

372. Marie v. Moser, 65 F. Supp. 3d 1175, 1206 (D. Kan. 2014).

373. Marie v. Moser Docket, Supreme Court Docket No. 14A503, http://www.sup remecourt.gov/search.aspx?filename $=/$ docketfiles/14a503.htm. The Supreme Court can grant a stay from "any case in which the final judgment or decree of any court is subject to review by the Supreme Court," even if the parties bypass the court of appeals. 28 U.S.C. 2101(f).

374. Marie v. Moser, No. 14A503 (Nov. 10, 2014) (order granting stay), http://www.supremecourt.gov/orders/courtorders/111014zr_0971.pdf.

375. Moser v. Marie, 135 S. Ct. 511 (2014).

376. Id.

377. Supra notes 367-69 and accompanying text. 
to the stay denials. On the other hand, none of the five Justices in the Obergefell majority spoke either to the earlier stay grants or the current stay denials.

\section{Eleventh Circuit}

Florida's challenge followed a similar path to Kansas's. Recall that Judge Hinkle had stayed his injunction until ninety days beyond the cert denials from the Tenth Circuit, ${ }^{378}$ a period due to expire on January 5, 2015. ${ }^{379}$ In December, the Eleventh Circuit declined to extend the stay beyond that date, stating that the "decision not to extend the stay is consistent with the Supreme Court's treatment of this issue." ${ }^{380}$ At that time, there was no stay in place from the Supreme Court in any case and no stay had remained in effect for more than two days since the cert denials. The Eleventh Circuit would never even have the case argued before the stay in Florida was lifted. In December, the Supreme Court denied Florida's stay request, again with Justices Scalia and Thomas dissenting, again without explanation. ${ }^{381}$

Two weeks later, on January 1, 2015, more than four months after his original injunction, Judge Hinkle described Florida's losing streak:

I stayed the ruling in this case while those stays were in effect and for 91 more days-long enough to allow the defendants to seek a further stay in the United States Court of Appeals for the Eleventh Circuit and, if unsuccessful there, in the United States Supreme Court. The defendants did that. They lost. The United States Supreme Court allowed the ruling in this case to take effect. ${ }^{382}$

378. See supra notes 275-78 and accompanying text.

379. Brenner v. Scott, No. 4:14-cv-107-RH/CAS (N.D. Fl. Nov. 5, 2014) (order denying the motions to alter stay), https://www.scribd.com/doc/272302072/14-11-05-OrderDenying-Motions-to-Alter-Stay.

380. Brenner v. Scott, No. 14-14061 (11th Cir. Dec. 2, 2014) (order declining to extend stay), https://www.scribd.com/doc/272315872/14-12-03-Order-Motion-to-Stay.

381. Armstrong v. Brenner, 135 S. Ct. 890 (2014).

382. Brenner v. Scott, No. 4:14CV107-RH/CAS, 2015 WL 44260, at *1 (N.D. Fla. 2015). 


\section{Fifth Circuit}

In November 2014, Judge Carlton Reeves of the Southern District of Mississippi invalidated that state's marriage ban. ${ }^{383}$ Although he declined to issue a stay pending appeal, he stayed the injunction for fourteen days to give the State time to appeal and allow the Fifth Circuit to decide whether a stay was appropriate. ${ }^{384} \mathrm{He}$ captured the choice as one between "a race to the courthouse-with same-sex couples rushing to the circuit clerk's office, and the State rushing to the Fifth Circuit," which, he insisted, "does not serve anyone's interest.",385

A unanimous panel of the Fifth Circuit granted the stay pending appeal ${ }^{386}$ something no other circuit had done since the cert. denials. Once again, the newly created circuit split loomed and may have affected the decision. The court insisted that it "is not our task today to resolve the merits of this conflict in deciding the instant motion, however, we are convinced by the opinions of our sister circuits that 'a detailed and in depth examination of this serious legal issue' is warranted before a disruption of a long standing status quo." 387 The court also emphasized the need to avoid confusion and the "inevitable disruption that would arise from a lack of continuity and stability in this important area of law." "388 In contrast, the Eleventh Circuit was not moved by the circuit split, denying a stay the following month.

\section{Eighth Circuit}

Three district judges in the Eighth Circuit took an unexpectedly narrow approach. They invalidated state laws but nevertheless stayed their judgments. ${ }^{389}$ Each court minimized the effects of the cert denials and the subsequent stay denials in Moser, Parnell, and Latta. The key was that those stay denials arose in circuits (Fourth, Ninth, and Tenth) that had previously entered Article III-final judgments

383. Campaign for S. Equal. v. Bryant, 64 F. Supp. 3d 906, 953 (S.D. Miss. 2014) aff'd, No. 14-60837, 2015 WL 4032186 (5th Cir. July 1, 2015).

384. Id.

385. Id

386. Campaign for S. Equal. v. Bryant, 773 F.3d 55, 58 (5th Cir. 2014).

387. Id. (quoting Baylor Univ. Med. Ctr., 711 F.2d at 40).

388. Id

389. Jernigan v. Crane, 64 F. Supp. 3d 1260, 1276 (E.D. Ark. 2014); Rosenbrahn v. Daugaard, 61 F. Supp. 3d 862, 876 (D.S.D. 2015); Lawson v. Kelly, 58 F. Supp. 3d 923, 936 (W.D. Mo. 2014). 
recognizing the constitutional right to same-sex marriage. Those stay denials therefore allowed judgments to take effect that were supported by binding precedent. By contrast, the Eight Circuit had not yet ruled on the constitutional question. Within the circuit, therefore, the situation was the same as prior to the cert denialsdistrict courts had enjoined state laws in the absence of binding precedent and stays were appropriate until those judgments became final or until binding precedent issued. ${ }^{390}$

On the other hand, such a formalistic approach disregards the Supreme Court's role as traffic cop in major constitutional cases. Through its shadow docket, the Supreme Court took steps to maintain the status quo throughout the courts of appeals, without granting certiorari or hearing cases on the merits. In fact, one commentator suggests that this approach enabled the Court to decide Obergefell while limiting its dramatic effect on broader U.S. society and the Court's institutional legitimacy. By delaying its decision on the merits, the Court allowed lower court decisions to establish marriage in more states over a longer period of time, leaving Obergefell to clean up in about a dozen stragglers at the final point. ${ }^{391}$

\section{E. Phase IV: Certiorari Granted: January 16-June 26}

On January 16, 2015-three months after the October cert denials and the denials of stays from Idaho, Alaska, South Carolina, Kansas, and Florida (the last two over dissents by Justices Scalia and Thomas) - the Court finally granted certiorari of the divided Sixth Circuit decision upholding marriage bans in Kentucky, Michigan, Ohio, and Tennessee. ${ }^{392}$

At that time, a number of cases remained pending in the district courts. The judges' easiest option would have been to stay the

390. Lawson v. Kelly, No. 14-0622-CV-W-ODS (W.D. Mo. Nov. 25, 2014) (order denying motion to stay), https://www.scribd.com/doc/272318247/14-11-25-Order-DenyingMotion-to-Lift-Stay; Rosenbrahn, 61 F. Supp. 2d at 876.

391. Chris Geidner, Cert.Denied, Stays Denied, Marriage Equality Advanced: How the Supreme Court Used Nonprecedential Orders to Diminish the Drama of the Marriage Equality Decision, 76 OHIO ST. L.J. FURTHERMORE 161, 171 (2015), http://moritzlaw.osu. edu/students/groups/oslj/files/2015/11/Vol.-76-161-172-Geidner-SCR-Essay.pdf.

392. The case would be Obergefell v. Hodges before the Court because the petition for certiorari from Tennessee was filed first, had the lowest docket number. Much to the chagrin of law professors and students for generations to come, Obergefell (pronounced "OH-ber-guh-fell") was also the most difficult name to pronounce of all the petitioners. Richard Wolf, Grieving widower takes lead in major gay marriage case, USA TODAY (Apr. 10, 2015), http://www.usatoday.com/story/news/nation/2015/04/10/supreme-court-gay-marr iage-obergefell/25512405/; Compare the aptly named Love v. Beshear, 989 F. Supp. 2d 536, 539 (W.D. Ky. 2014). 
litigation, given that a final, binding resolution of the constitutional issue was only a few months away. There was nothing to be gained from new lower court precedent. And there certainly was nothing to be gained from states issuing new marriage licenses based on a constitutional judgment that might be overruled in short order. One district court in the Middle District of Alabama did just this, denying the state's motion to dismiss, ${ }^{393}$ then immediately staying the litigation until that definitive ruling from the Supreme Court. ${ }^{394}$ The Eighth Circuit stayed an injunction from Nebraska. Opting for the leastefficient approach, the Eleventh Circuit declined to stay the injunction, as did the Supreme Court, prompting a vigorous written dissent from Justices Thomas and Scalia.

\section{Eighth Circuit}

District courts in the Eighth Circuit continued to grant timelimited stays or stays pending appeal, although with limited analysis. After invalidating Nebraska's marriage law, Judge Joseph E. Bataillon granted a one-week stay. ${ }^{395}$ Ironically, the district court justified its decision by citing to the Supreme Court's denial of a stay and Justice Thomas's dissent on the issue. ${ }^{396}$ In other words, a single dissent from the denial of a stay from two Justices trumped the significance of six consecutive and unexplained denials of stay from seven Justices. Similarly ignoring the Court's newer signals, the Eighth Circuit, without any analysis or noted dissent, stayed the injunction pending appeal four days later. ${ }^{397}$

By issuing the stay in the face of the Court's recent denials, these courts echoed in reverse those judges in Michigan and Indiana who had refused to grant stays when the prevailing signal from the Court was to grant them. ${ }^{398}$ All were saying, in essence, that the Court's decisions with respect to stays-orders from its shadow docket-

393. Hardy v. Bentley, No. 2:13-CV-922-WKW, 2015 WL 1043159, at*1 (M.D. Ala. Mar. 10, 2015).

394. Hardy v. Bentley, No. 2:13-CV-922-WKW (M.D. Ala. Mar. 10, 2015) (order granting stay), https://www.scribd.com/doc/272319130/15-03-10-Order-Staying-Case-UntilDisposition-of-Supreme-Court-Cases.

395. Waters v. Ricketts, 48 F. Supp. 3d 1271, 1290-91 (D. Neb. 2015).

396. Id. at 1287 n.15 (citing Strange v. Searcy, 135 S. Ct. 940 (2015)).

397. Waters v. Rickets, No. 15-1452 (8th Cir. Mar. 6, 2015) (order granting motion to stay), https://www.scribd.com/doc/272319674/15-03-06-Order-Granting-Motion-to-StayAppeal.

398. DeBoer v. Snyder, 973 F. Supp. 2d 757, 775 (E.D. Mich. 2014); Baskin v. Bogan, 12 F. Supp. 3d 1144, 1149 (S.D. Ind. 2014). 
carried no precedential force. As Judge White of the Sixth Circuit had observed while dissenting from the stay in the Michigan case, the stay in Kitchen was "without a statement of reasons, and therefore the order provides little guidance." 399 The same went for the denials of stay and denials of certiorari in subsequent cases.

\section{Eleventh Circuit}

The final leg in this relay race involved challenges to Alabama's marriage ban. Almost overnight, Alabama sparked the most intense media attention, as well as the greatest legal, judicial, and political confusion. $^{400}$ On January 23, 2015-one week after the Obergefell cert. grant-Judge Granade of the Southern District of Alabama declared that state's marriage ban unconstitutional and enjoined its enforcement. ${ }^{401}$ Two days later, she stayed the judgment for fourteen days to give the Eleventh Circuit an opportunity to determine whether a stay would be appropriate. ${ }^{402}$ That same day, in a parallel case by same-sex couples seeking marriage licenses, Judge Granade again declared the ban invalid, enjoined its enforcement, and stayed the order for fourteen days. ${ }^{403}$

Less than two weeks later, the Eleventh Circuit denied stays in the consolidated cases, consistent with its approach since the October cert denials. ${ }^{404}$ Later that day, Judge Granade denied the Plaintiffs' motion to immediately lift the stay, but ordered that "[i]f the Supreme Court denies a stay or does not rule before February 9, 2015 , this court's stay will still remain in place until that date to allow the Probate Courts of this state to be completely prepared for compliance with the rulings in this case and the Strawser case."

399. DeBoer v. Snyder, No. 14-01341 (6th Cir. Mar. 25, 2014) (order granting stay), https://www.scribd.com/doc/270993306/DeBoer-v-Snyder-14-3-25-ORder-Granting-Stay (White, J., dissenting).

400. See Wasserman, supra note 7, at 2.

401. Searcy v. Strange, 81 F. Supp. 3d 1285, 1286 (S.D. Ala. Jan. 23, 2015). Unfortunately, the case itself had inherent procedural problems-it involved a married couple seeking a second-parent adoption rather than couples seeking licenses, and the only named defendant was Attorney General Luther Strange, who had no role to play in either the adoption or issuance of marriage licenses. Wasserman, supra note 7, at 3-4.

402. Searcy, 81 F. Supp. 3d at 1288-89.

403. Strawser v. Strange, No. 14-0424-CG-C (S.D. Ala. Jan. 26, 2015) (order granting stay), https://www.scribd.com/doc/272322643/15-01-26-Order-Granting-Stay.

404. Searcy v. Strange, No. 15-10295-C (11th Cir. Feb. 3, 2015) (order denying stay), https://www.scribd.com/doc/272322995/15-2-3-denial-stay.

405. Searcy v. Strange, No. 1:14-cv-208-CG-N (S.D. Ala. Feb. 3, 2015) (order denying motion to lift stay), https://www.scribd.com/doc/272323118/15-2-3-denying-motion-liftstay-pdf. 
On February 9, the Supreme Court denied the eighth and final application for a stay in a same-sex marriage cases. Once again, Justices Thomas and Scalia dissented from the denial of the stay. Perhaps recognizing that this would be the final opportunity to address the stay issue, Justice Thomas (finally) explained his reasoning. His explanation captured the ebb and flow of the four paradigms leading to this point and offered a rare insight into the inner workings of the shadow docket.

He began by citing Kitchen, explaining that the "ordinary practice" when a lower court enjoins state officials from enforcing laws declared unconstitutional is to "suspend those injunctions from taking effect pending appellate review." ${ }^{406}$ Thomas insisted that it would be the "rare case" in which a state could not make some showing of likelihood of success on the merits. Similarly, a state suffers irreparable injury whenever it is precluded from enforcing laws that had been duly enacted by the public's representatives. Thus, he insisted, it was "no surprise" that the court had stayed the orders from the Fourth and Tenth Circuits in Kitchen, Evans, and Bostic.

Further, it was "of no moment" that the Court had recently denied several stay applications in Latta and others, because those followed the October cert denials. While disagreeing with those stay denials, he acknowledged that there was at least an argument that the October decision justified an inference that the Court would be less likely to grant a writ of certiorari to consider subsequent petitions. But that dynamic was inverted anew by the cert grant in Obergefell, which guaranteed a decision on the merits by the end of the Term. The October inference was "no longer credible." Thomas labeled it "regrettable" that the district court in the Alabama case made no effort to preserve the status quo pending the Supreme Court's decision on a difficult and open constitutional question. ${ }^{407}$

He then jumped to the real heart of the matter-the Court's shadow docket and the way an unexplained order had effectively preordained the outcome:

This acquiescence may well be seen as a signal of the Court's intended resolution of that question. This is

406. Strange v. Searcy, 135 S. Ct. 940 (2015) (Thomas, J., dissenting from denial of application for stay).

407. Id. at 941 (Thomas, J., dissenting from denial of application for stay) (citing United States v. Windsor, 133 S. Ct. 2675, 2695-96 (2013)). 
not the proper way to discharge our Article III responsibilities. And, it is indecorous for this Court to pretend that it is. Today's decision represents "yet another example of this Court's increasingly cavalier attitude toward the States." ${ }^{408}$

Denying the stay, Justice Thomas concluded, does not show "the people of Alabama the respect they deserve and preserve[] the status quo while the Court resolves this important constitutional question." 409

In Thomas's view, this was the most blatant example of the Court signaling substantive results through shadow-docket orders, eliminating any possible doubt that the district court injunction would stand. He accused the rest of the Court of "cavalier[ly]" hands of its responsibility to maintain the status quo before Obergefell would definitively resolve the issue only three months later.

\section{F. The Shadow Docket and High-Stakes Litigation}

The same-sex marriage cases offer an important lesson for highstakes civil rights litigation-the Justices, and not the inferior courts, decide when and how momentous constitutional issues are resolved. Each of the district courts that declined to grant a stay did so based on their own independent judgment of how the traditional four factors balanced. In the quotidian case, a district court judge's individual assessment of whether the plaintiffs are likely to succeed on the merits or whether there would be irreparable harm, would suffice to resolve whether a stay should be granted.

This was not your everyday civil rights litigation, however. From the initial decision to stay the judgment in Utah, the Supreme Court maintained total control over how the litigation would proceed throughout the lower courts. In keeping with the Justices' broader

408. Id. (Thomas, J., dissenting).

409. Id. (Thomas, J., dissenting). In his dissent in Arizona State Legislature v. Arizona Independent Redistricting Commission later that term, Justice Thomas sounded a similar theme, citing to the October cert denials and commenting that "Court's lack of respect for ballot initiatives is evident not only in what it has done, but in what it has failed to do." 135 S. Ct. 2652, 2698 (2015) (Thomas, J., dissenting). Id. ("The Court "refused to grant a stay pending appeal of a decision purporting to require the State of Alabama to issue marriage licenses to same-sex couples, even though Alabama's licensing laws had not been challenged in that case.") (citing Strange v. Searcy, 135 S. Ct. 940 (2015)).

410. Searcy, 135 S. Ct. at 941 (Thomas, J., dissenting from denial of application for stay). 
sense of taking the cases when they thought the country was ready for nationwide same-sex marriage, the Justices also attempted to exercise oversight over how the lower courts managed the issues. Between Utah's judgment, and the denials of certiorari in October, district and circuit judges that disregarded the signals from the shadow docket were quickly reversed by per curiam stays, with no explanation. Should the judges who exercised their independent judgment-in conflict with signals from the Supreme Court's shadow docket-be faulted? It depends on the proper orientation of this type of litigation.

On the one hand, if we start from the proposition that each district court has the authority to decide cases or controversies before it, bound only by actual circuit or Supreme Court precedent, the courts that declined stays acted properly. A single-sentence order from the Supreme Court, without analysis or explanation, is not binding or even persuasive precedent. The lower courts thus could not be faulted for predicting-correctly as it turned out-that the marriage laws were unlikely to survive on appeal and that same-sex couples would suffer injuries during the litigation process. This perspective offers the greatest defense for judges that refused to grant stays.

On the other hand, such a formalistic approach disregards the Supreme Court's role as traffic cop in major constitutional cases. Through its shadow docket, the Supreme Court took steps to maintain the status quo throughout the courts of appeals, without granting certiorari or hearing cases on the merits.

And this dynamic need not be limited to the marriage cases. For example, religious nonprofits in nearly every circuit alleged that an accommodation to the Affordable Care Act contraception mandate violated the Religious Freedom Restoration Act. Even though the courts of appeals have uniformly upheld the accommodation and would have allowed the mandate against the plaintiffs to go into effect, the Supreme Court has repeatedly halted enforcement of the mandate pending appeal. ${ }^{411}$ It will be up to the Supreme Court, and not the lower courts, to resolve this important issue. ${ }^{412}$ Even if the

411. Little Sisters of the Poor Home for the Aged v. Sebelius, 134 S. Ct. 1022 (2014); Wheaton Coll. v. Burwell, 134 S. Ct. 2806, 2807 (2014); Zubik v. Burwell, 135 S. Ct. 2924 (2015).

412. Professor Blackman filed a brief in support of certiorari in Little Sisters of the Poor v. Burwell. See Brief for the Cato Institute as Amicus Curiae in Support of Petitioners, Little Sisters of the Poor v. Burwell, 794 F. 3d 1151 (10th Cir. 2015), cert 
Court ultimately upholds the accommodation, the status quo will be maintained until the Justices decide otherwise.

The stays in Kitchen, Evans, and Bostic were not routine orders, but quick and unanimous repudiations of courts that immediately altered the status quo before the Court had formally evaluated the issue. Only after the Court considered and denied the petitions for certiorari could the stays be lifted. The Long Conference when the voted to deny the petitions constituted the first official opportunity for the Justices to share their views. After that point, by rejecting the petitions, the Justices had then effectively stamped their imprimatur on marriage equality - seeing no need to reverse the lower courtsand allowed the district judges to let their judgments go into effect.

With the same-sex marriage cases, the Supreme Court aggrandized for itself the role as the arbiter of the status quo in highstakes civil rights litigation, albeit silently. District judges-even those who blanch at this repudiation of their independent judgments-are now on notice that injunctions should be put on hold after the Supreme Court has taken an interest in an issue. ${ }^{413}$ In future high-stakes constitutional litigation, judges and parties must understand this and work in accordance with this background principle.

\section{State Litigation and Federal-State Conflicts}

With the tide in lower federal courts moving ineluctably and irreversibly towards recognition of a constitutional right to same-sex marriage, officials in several states sought to at least slow, if not stem, the tide through state court litigation. Three states initiated state mandamus actions in an effort to forestall same-sex marriages by preventing county-level officials from voluntarily complying with persuasive federal precedent. ${ }^{414}$ This created a potential new procedural hurdle, as attorneys general then attempted to use the state litigation they had initiated to keep federal courts from hearing and ruling on the constitutional question. Federal courts uniformlyand appropriately-rejected these arguments. But their decisions

granted in part, 2015 WL 6759642 (U.S. Nov. 6, 2015) (No. 15-105), http://www.scotusblog.com/wp-content/uploads/2015/08/15-105-tsac-Cato-Institute.pdf.

413. In a related context, the Supreme Court has shown a propensity for granting certiorari a second time on cases that already have drawn its interest. In recent years, the Court has twice granted certiorari in Bond v. United States, Zivotofsky v. Clinton, Horne v. U.S. Department of Agriculture, and Fisher v. University of Texas. See Richard Re, SCOTUS Repeaters, PRAWFSBLAWG (Jan. 16, 2015), http://prawfsblawg.blogs.com/ prawfsblawg/2015/01/scotus-repeaters.html.

414. Supra notes 304-05 and accompanying text. 
illustrate another round of issues that may arise in future civil rights litigation.

\section{A. State Mandamus Proceedings}

We previously discussed conflicts in Kansas and South Carolina, where county-level officials indicated their intent to voluntarily comply with binding circuit precedent addressing identical laws in other states. Officials in both states, recognized the inevitability of a federal lawsuit and adverse judgment that would invalidate their state bans, enjoining their enforcement, and imposing attorney's fees. ${ }^{415}$ In response, attorneys general in both states initiated actions in the state Supreme Court's original jurisdiction, seeking a writ of mandamus to stop local officials from this voluntary compliance. ${ }^{416}$ Neither state court reached the merits of the constitutional issue, but both temporarily stayed local officials from issuing licenses, at least until resolution of then-pending challenges to the state laws in federal district court. ${ }^{417}$ In both cases, the local officials named as respondents on the mandamus petition took no position on the merits and simply simply asked the state Supreme Court to provide guidance on how they should proceed. ${ }^{418}$

A similar tactic might have been appropriate in Wisconsin, where clerks statewide began issuing marriage licenses to same-sex couples following the district court declaration's of the ban's unconstitutionality but before entry of any injunction. ${ }^{419}$ The district court insisted, correctly, that these clerks were not acting under compulsion of a court order and thus were not subject to the court's control. ${ }^{420}$ A mandamus action by the attorney general in the Wisconsin Supreme Court, ordering clerks to cease granting licenses until a binding federal order issued, would have been an appropriate move to stop this voluntary compliance.

Reflecting a common theme, ${ }^{421}$ things got far more complicated and confrontational in Alabama, the third state in which an original

415. Supra notes 102, 105 and accompanying text.

416. State ex rel. Schmidt v. Moriarty, No. 112, 590 (Kan. Oct. 10, 2014); State ex rel. Wilson v. Condon, 764 S.E. 2d 247 (S.C. 2014).

417. Schmidt, No. 112, 590; Wilson, 764 S.E. $2 d$ at 247.

418. Id.

419. See supra notes 292-309 and accompanying text.

420. Wolf v. Walker, No. 14-cv-64-bbc (7th Cir. June 9, 2014) (order denying emergency motion for stay), https://www.scribd.com/doc/271058059/Wolf-v-Walker-14-0609-Order-Denying-Emerngency-Motion-for-Stay.

421. Wasserman, supra note 7, at 10. 
jurisdiction mandamus petition pulled the state Supreme Court into the mix. Judge Granade invalidated the state ban and ordered one state probate judge to issue licenses to four named couples. ${ }^{422}$ Two private parties, acting as relators of the State, then initiated the mandamus action in the Supreme Court of Alabama. ${ }^{423}$ This action was potentially broader than the ones in Kansas and South Carolina, as it sought to prohibit all probate judges in the state from issuing licenses to any same-sex couples, in the wake of numerous judges voluntarily complying with Judge Granade's decision.

Most importantly, unlike in Kansas and South Carolina, the Supreme Court of Alabama reached the merits of the constitutional question. In a 134-page per curiam opinion, six justices-the controversial Chief Justice Moore recused-held that Alabama's same-sex marriage ban was constitutionally valid and must be enforced. The court rejected concerns about the organizations' standing as relators, questions about the court's own jurisdiction, contrary decisions from the Southern District of Alabama and numerous other lower federal courts, and repeated signals from the Supreme Court of the United States. ${ }^{424}$ The result of this judgment was statewide uniformity going forward-no same-sex couples could obtain marriage licenses, except for those four couples already entitled to licenses from one probate judge under Judge Granade's injunction. Importantly, the court did not invalidate the marriages of those four couples or any other couple voluntarily issued a license by other judges in the state.

As a starting point, there is nothing inherently problematic with a decision by a state court contradicting, or simply declining to defer to, a decision by a lower federal court. Interpretations of federal law by lower federal courts do not bind state courts, except to the extent state courts choose to be bound as a matter of state law. ${ }^{425}$ State courts are presumed to have concurrent jurisdiction over federal law

422. See supra notes 55-57, 400-02 and accompanying text.

423. Ex parte State ex rel. Ala. Policy Inst., No. 1140460, 2015 WL 892752, at*43 (Ala. Mar. 3, 2015). Because Attorney General Strange was enjoined from enforcing the samesex marriage ban, Strawser v. Strange, No. 14-0424-CG-C, 2015 U.S. Dist. LEXIS 8439, at *4 (S.D. Ala. Jan. 26, 2015), he did not, and arguably could not, litigate the mandamus petition.

424. Ala. Policy Inst., 2015 WL 892752, at *25, *43; see also Wasserman, supra note 7, at $11-12$.

425. Frost, supra note 28, at 55; Logan, supra note 28, at 236-37. 
issues and function as inferior federal tribunals. ${ }^{426}$ They are vested with the same interpretive leeway on the meaning of federal law as any lower federal court, bound only by Supreme Court precedent and subject only to Supreme Court review. ${ }^{427}$ The Supreme Court of Alabama could diverge from a federal district court on a constitutional question, just as two federal district courts (even within the same state or the same district) can diverge.

State courts were entirely within their unquestioned power and discretion in not treating the Fourteenth Amendment issue as conclusively resolved and in reaching a different constitutional conclusion than did the federal district court. One might disagree with the merits of that decision. ${ }^{428}$ But disagreement with a state court decision on a question of federal law does not render that decision illegitimate any more than disagreement with the federal judge renders her decisions illegitimate. Nor do divergent results mean that the state court has rebelled against the federal court, since they stand on equal footing.

\section{B. Abstention}

The state mandamus actions raised the separate question of whether potential federal-state conflicts presented by permissible parallel state court litigation should have limited new or pending federal constitutional litigation. While the state courts were rendering their decisions, there were lawsuits pending in the District of South Carolina ${ }^{429}$ and the District of Kansas, ${ }^{430}$ as well as motions to certify the Southern District of Alabama case as a class action and to extend the existing injunction. ${ }^{431}$ Officials in all three states argued that the federal courts were required to abstain, on a number of different bases, in deference to these state judicial and political processes.

426. Claflin v. Houseman, 93 U.S.130, 136 (1876). Josh Blackman, State Jurisdictional Sovereignty, 2016 ILL. L. REV. (forthcoming 2016), http://papers.ssrn.com/sol3/papers .cfm?abstract_id=2466845.

427. James E. Pfander, Federal Supremacy, State Court Inferiority, and the Constitutionality of Jurisdiction-Stripping Legislation, 101 Nw. U. L. REV. 191, 234 (2007).

428. See generally Adam Lamparello, Why Chief Justice Roy Moore and the Alabama Supreme Court Just Made the Case for Same-Sex Marriage, 17 U. PA. J. Const. L. (ONLINE) 1 (2015).

429. Condon v. Haley, 21 F. Supp. 3d 572 (D.S.C. 2014).

430. Marie v. Moser, 65 F. Supp. 3d 1175 (D. Kan. 2014).

431. Strawser v. Strange, No. 14-0424-CG-C, 2015 WL 2449468, at *1, *6 (S.D. Ala. May 21, 2015); see supra Part I.D. 


\section{Pullman Abstention}

Federal courts abstain under Pullman ${ }^{432}$ when the challenged state law is ambiguous, difficult, uncertain, or unclear; by abstaining, federal courts afford state courts an opportunity to interpret the state law and perhaps to eliminate the federal constitutional defect, thereby obviating the federal constitutional question. ${ }^{433}$ Importantly, however, abstention is appropriate only when the challenged law is ambiguous and reasonably capable of a construction that would "render unnecessary or substantially modify" the federal constitutional question. ${ }^{434}$ Moreover, the uncertain or difficult question must go to the challenged law itself, not the validity of that law under the federal or state constitutions. And Pullman is not an exhaustion requirement-state courts need not be given a first opportunity at determining the law's validity, including under parallel state Equal Protection or Due Process provisions. ${ }^{435}$

The District of Kansas recognized that Pullman was inapplicable, as there was no ambiguity or lack of clarity in Kansas's marriage laws. The laws "unequivocally prohibit plaintiffs and other same-sex couples from procuring a marriage license and marrying a person of the same sex in Kansas," and had been applied consistent with that plain meaning. There was no way a state court could interpret the laws to avoid the constitutional concerns. ${ }^{436}$

The Kansas decision contrasts with the Ninth Circuit's inappropriate use of Pullman in a pre-Windsor same-sex marriage case. The difference in their approaches demonstrates how quickly understandings of marriage equality, and its constitutional status, evolved. In 2006, the Ninth Circuit held that a district court properly abstained under Pullman from a challenge to the state's then-existing statutory ban on same-sex marriage in deference to ongoing litigation challenging that ban under the state constitution. Abstention was proper because that state litigation could have resolved the constitutionality of the same-sex marriage ban and the court of

432. Railroad Comm'n of Texas v. Pullman Co., 312 U.S. 496 (1941).

433. Arizonans for Official English v. Ariz., 520 U.S. 43, 76 (1997); Pullman, 312 U.S. at 51; see also Ashwander v. Tenn. Valley Auth., 297 U.S. 288, 341 (1936) (Brandeis, J., concurring).

434. City of Houston v. Hill, 482 U.S. 451, 468 (1987); Wisconsin v. Constantineau, 400 U.S. 433, 438-39 (1971).

435. Constantineau, 400 U.S. at 437-39.

436. Marie, 65 F. Supp. 3d at 1195. 
appeals could not predict its outcome. ${ }^{437}$ The court never considered the complete absence of ambiguity in the underlying marriage ban being challenged. Nor did the court recognize its misstep in treating Pullman as an exhaustion requirement, an obligation to allow state courts to offer a first answer to the constitutional question.

While legally erroneous, the Ninth Circuit's decision may be a product of its time. In 2004, voters in eleven states approved measures to amend state law or the state constitution to preclude same-sex marriage. ${ }^{438}$ It was inconceivable that, less than two years later, a federal court would declare that such bans violate the Constitution. Abstention doctrines often are criticized as too-readily manipulable, offering federal courts a way to avoid confronting important constitutional questions. ${ }^{439}$ Smelt reflects that tendency, at a time when reaching a decision on the merits only could have produced a constitutional decision adverse to the plaintiffs. Of course, this erroneous decision arguably proved beneficial to the marriage equality movement, as the district court in Perry (five years later, but a world away socially) did not have adverse binding precedent to overcome.

\section{Younger Abstention}

Younger $^{40}$ abstention prohibits federal courts from interfering with an ongoing state proceeding, specifically through the issuance of an injunction or declaratory judgment that would result in a stay of the state proceedings. ${ }^{441}$ Younger rests on "Our Federalism," under which state institutions must be given an opportunity to decide federal constitutional questions in the course of their own

437. See Smelt v. Cty. of Orange, 447 F.3d 673, 678-82 (9th Cir. 2006). Ultimately, the Supreme Court of California held that the marriage ban violated the equal protection and due process provisions of the state constitution. See In re Marriage Cases, 43 Cal. 4 th 757 (2008). California voters overruled that decision several months later, overwhelmingly approving Proposition 8, which amended the State Constitution to provide that: "Only marriage between a man and a woman is valid or recognized in this state." Proposition 8 was declared invalid by a federal district court in Perry in 2011, starting the two-year sprint to nationwide marriage equality.

438. Daniel A. Smith, Matthew DeSantis \& Jason Kassell, Same-Sex Marriage Ballot Measures and the 2004 Presidential Election, 38 STATE \& LOCAL GOVT. REV. 78 (2006).

439. MARTIN H. REDISH, FEDERAL JURISDICTION: TENSIONS IN THE ALLOCATIONS OF POWER (1990); Burt Neuborne, The Myth of Parity, 90 HARV. L. REV. 1105, 1109-10, 1117 (1977).

440. Younger v. Harris, 403 U.S. 37 (1971).

441. Samuels v. Mackell, 403 U.S. 66, 71-72 (1971); Younger, 403 U.S. at 49. 
proceedings. ${ }^{442}$ The Supreme Court recently insisted that Younger only applies to three categories of state proceedings-criminal prosecutions; civil, "quasi-criminal" enforcement proceedings; and civil proceedings involving certain orders uniquely in furtherance of state courts' ability to perform their judicial functions. ${ }^{433}$ In addition, the state proceeding must be one in which the federal plaintiff would have an adequate opportunity to litigate the federal constitutional issues. $^{444}$ Finally, Younger prohibits federal courts from halting ongoing state proceedings; it does not apply to parallel state-federal litigation that happens to deal with similar issues. ${ }^{44}$

As applied to the same-sex marriage cases, Younger arguments failed for several reasons. First, because the federal plaintiffs were not parties to the state mandamus proceedings, they did not have an adequate opportunity to litigate their federal claims in those proceedings. ${ }^{46}$ Second, mandamus actions did not fit in any of the three categories of state proceedings warranting Younger abstention. These federal actions did not challenge laws affecting state courts' power to enforce judgments, such as contempt statutes or appellate bond requirements. Rather, they challenged the way state officials performed the executive function of issuing marriage licenses in light of state laws banning same-sex marriage. ${ }^{447}$

Third, the federal action did not seek an injunction that would halt or otherwise interfere with the state mandamus proceedings. A federal injunction requiring defendant officials to issue marriage license to same-sex couples might impose obligations on those officials that conflicted with the state mandamus obligations. But Younger is not concerned with simple parallel litigation or conflicting obligations derived from competing litigation. There are other ways to deal with those potential conflicts without the federal court staying its hand entirely. For example, the Alabama mandamus decision allowed officials subject to an ongoing federal injunction an opportunity to be excused from the mandamus. ${ }^{448}$

\footnotetext{
442. Younger, 403 U.S. at 44-45.

443. Sprint Commc'ns, Inc. v. Jacobs, 134 S. Ct. 584, 591 (2013).

444. Middlesex Cty. Ethics Comm'n v. Garden State Bar Assn., 457 U.S. 423, 432 (1982).

445. Sprint, 134 S. Ct. at 593.

446. Marie v. Moser, 65 F. Supp. 3d 1175, 1197 (D. Kan. 2014).

447. Id.; Condon v. Haley, 21 F. Supp. 3d 572, 581 (D.S.C. 2014).

448. See, e.g., Ex parte State ex rel. Ala. Policy Inst., No. 1140460, 2015 WL 892752, at *42 (Ala. Mar. 3, 2015); Wasserman, supra note 7, at 12-13.
} 


\section{Rooker-Feldman and its Misuse}

Rooker-Feldman ${ }^{449}$ derives from an interpretation of the respective statutory grants of federal jurisdiction to the Supreme Court and the federal district courts. The latter can only exercise original jurisdiction over federal constitutional claims, while review of final state court judgments on federal questions is vested exclusively in the former. ${ }^{450}$ In practice, Rooker-Feldman prevents a "state-court loser" from bringing an action in federal court claiming a constitutional injury caused by a state judgment or order that was entered prior to initiation of the federal action. ${ }^{451}$ Such a federal lawsuit improperly invites district courts to review and reject a state judgment. But Rooker-Feldman plays no role where the federal action challenges conduct independent of a state court order. Moreover, as the Supreme Court recently clarified, the doctrine is not triggered by parallel litigation or the potential preclusive effects of parallel federal-state litigation. ${ }^{452}$

Federal courts easily swept aside this argument as to the state mandamus proceedings. Most obviously, the federal plaintiffs were not parties to the mandamus action, so they could not qualify as "state-court losers." 453 Nor did the federal plaintiffs challenge the state court judgments imposing the mandamus. Rather, they challenged the state prohibition on same-sex marriage and the refusal of state officials-not the state courts-to perform the executive function of issuing marriage licenses. ${ }^{454}$ That a federal action may overlap or conflict with the state proceeding did not strip the federal court of jurisdiction. ${ }^{45}$

Interestingly, the failure of parties and the court to recognize genuine Rooker-Feldman issues contributed to some of the confusion in Alabama in the months prior to Obergefell. That failure produced an arguably premature and ineffectual federal decision that had no

449. See Dist. of Columbia Court of Appeals v. Feldman, 460 U.S. 462 (1983); Rooker v. Fidelity Trust Co., 263 U.S. 413 (1923).

450. Exxon Mobil Corp. v. Saudi Basic Indus. Corp., 544 U.S. 280, 291-92 (2005); compare 28 U.S.C. $\$ 1257$ with 28 U.S.C. $\$ 1331$.

451. Exxon Mobil, 544 U.S. at 284.

452. Id. at 292

453. Marie v. Moser, 65 F. Supp. 3d 1175, 1190-1200 (D. Kan. 2014); Strawser v. Strange, No. 14-0424-CG-C, 2015 WL 2449468, at *1, *6 (S.D. Ala. May 21, 2015).

454. Marie, 65 F. Supp. 3d at 1200.

455. Id. 
meaningful legal effect and did not fit with broader efforts of couples to obtain marriage licenses.

The first case in which Judge Granade of the Southern District of Alabama declared the state marriage ban unconstitutional was Searcy v. Strange. The plaintiffs in Searcy were a couple, Cari Searcy and Kimberly McKeand; they were lawfully married in California, and wanted Searcy to second-parent adopt McKeand's biological son. Under Alabama law, a stepparent may adopt the child of a "spouse." 456 But because state law prohibited same-sex marriages or the recognition of out-of-state same-sex marriages, Searcy and McKeand could not qualify as spouses and Searcy was ineligible to adopt McKeand's biological child. ${ }^{457}$ The state trial court denied the petition, the Alabama Court of Civil Appeals affirmed, and the plaintiffs did not seek further review, rendering the state court judgment final. ${ }^{458}$

Searcy and McKeand then sued in federal court, seeking to enjoin enforcement of the state marriage bans. The couple insisted that "they 'have exhausted all avenues of legal recourse in Alabama state courts and [are] left without the remedy they seek-the adoption." ${ }^{459}$ Alabama Probate Judge Don Davis, who had denied the adoption petition, was initially named as defendant, but the parties voluntarily dismissed the claims against him (rather than contest his motion to dismiss). The case proceeded only against Attorney General Luther Strange. And although Strange played no role in the adoption action, in late January 2015, the district court nevertheless enjoined him from enforcing the marriage ban as to these plaintiffs. ${ }^{460}$

Rooker-Feldman should have stripped the district court of jurisdiction over this action. Searcy and McKeand were state court losers. They sought the adoption in state court and were denied by the state courts in clear judicial acts by Judge Davis and the Court of Civil Appeals. ${ }^{461}$ And their complaint in federal district court

456. ALA. CODE $\S 26-10 \mathrm{~A}-27$.

457. In re Adoption of K.R.S., 109 So. $3 d 176$ (Ala. Civ. App. 2012).

458. Id.

459. Searcy v. Strange, No. 14-0208-CG-N, 2014 WL 4322396, *2 (S.D. Ala. Aug. 28, 2014).

460. Searcy v. Strange, 81 F. Supp. 3d 1285 (S.D. Ala. Jan. 23, 2015).

461. Judge Davis moved to dismiss the action against him by insisting that he enjoyed judicial immunity from suit for the judicial act of denying the adoption; the plaintiffs voluntarily dismissed him from the action, so the court never acted on the motion. His judicial immunity argument was wrong as a matter of law, since judicial immunity does not apply to claims for injunctive or declaratory relief, although the plaintiffs must seek 
expressly sought a judgment rejecting the state courts' conclusion, declaring that Searcy was legally entitled to adopt McKeand's child, and ordering the state court to approve that adoption. Although the plaintiffs framed their federal action as a challenge to the constitutionality of the same-sex marriage ban, the cause of their constitutional injury was the denial of the adoption by the state courts, based on the conclusion (commanded by the state marriage ban) that Searcy was not McKeand's spouse. Having exhausted their state court options, the couple's next move should have been to seek review of the final judgment in the Supreme Court of the United States. ${ }^{462}$ Unfortunately for the plaintiffs, that option was foreclosed because they never raised their federal constitutional challenge to the marriage ban in the state adoption proceeding. ${ }^{463}$ But failure to raise necessary issues in state court and to preserve them for Supreme Court review does not expand the jurisdiction of a federal district court to review or overrule a state court judgment.

The result in Searcy was a legally ineffectual injunction that, while not creating actual mischief, certainly created confusion. The injunction prohibited Attorney General Strange from enforcing the state marriage ban, but did not provide Searcy and McKeand with any relief because Strange played no role in granting adoption petitions or in controlling how probate judges decide adoption petitions. The injunction did not-and could not-require the state courts to grant the adoption petition. Nor did the injunction guarantee same-sex couples marriage licenses, since the plaintiffs were not seeking a marriage license. This confusion reached its nadir in early February when the stay of the Searcy injunction was lifted and the plaintiffs sought to hold Judge Davis in contempt for failing to issue marriage licenses to same-sex couples. Judge Granade properly denied the motion, recognizing that Davis was not a party to the action and thus not bound by the injunction or obligated to do anything under it. ${ }^{464}$ Had the parties and Judge Granade recognized

declaratory relief first and only may obtain an injunction if declaratory relief fails to provide a remedy.

462. 28 U.S.C. $\$ 1257$ (a).

463. In re Adoption of K.R.S, 109 So. 3d at 178.

464. Searcy v. Strange, No. 14-0208-CG-N, 2015 WL 519725, at*1 (S.D. Ala. Feb. 9, 2015); Wasserman, supra note 7, at 6 . Simultaneously, in an action brought by same-sex couples seeking marriage licenses, Judge Granade granted plaintiffs leave to amend their complaint to add Judge Davis as a defendant, then extended her earlier injunction, requiring Judge Davis to refrain from enforcing the state marriage ban and to issue licenses to the plaintiff couples. Strawser v. Strange, 44 F. Supp. 3d 1206, 1207-09, 1210 
the Rooker-Feldman concerns in the first instance, the case never would have reached this point.

Several days after Judge Granade expanded the Strawser injunction to prohibit Judge Davis from enforcing the marriage ban, ${ }^{465}$ Judge Davis issued an interlocutory order in the Searcy-McKeand adoption petition. He granted Searcy temporary parental rights, but ordered that the "[d]ecree is qualified in nature, and the Court will not issue a final adoption order until a final ruling is issued in the United States Supreme Court on the Marriage Act cases before it." ${ }^{466}$ Searcy in turn filed a new lawsuit against Davis in the Southern District of Alabama (again assigned to Judge Granade), seeking an injunction ordering Davis to grant the adoption without further delay and to strike the interlocutory order, as well as damages. ${ }^{467}$

The Rooker-Feldman problem with this lawsuit was even more glaring than the first. Once again, Searcy had sought a remedy-the final adoption-in state court and was denied, making her a state court loser. She then went to federal district court seeking to enjoin the state judges to grant that very remedy, as well as damages caused by the denial of the adoption in state court. A federal judge only could grant those remedies by concluding that the state judge erred in not granting the adoption, ${ }^{468}$ precisely what Rooker-Feldman prohibits federal district courts from doing.

The several lawsuits involving the Searcy-McKeand adoption arguably reflected the worst misunderstandings of federal jurisdiction and procedure, in a legal controversy full of them. This is not to suggest that Alabama's ban on same-sex marriage did not deprive these women of their constitutional rights, only that they picked the wrong process through which to vindicate those rights. ${ }^{469}$

(S.D. Ala. 2015); Wasserman, supra note 7, at 6-7. That injunction then began driving the issuance of licenses in the state. Id.

465. Strawser, 44 F. Supp. 3d at 1207-09.

466. Brendan Kirby, Mobile probate judge won't approve adoption in gay marriage case; plaintiffs file new suit, AL.COM (Feb. 24, 2015), http://www.al.com/news/mobile /index.ssf/2015/02/mobile_probate_judge_wont_appr.html.

467. Howard Wasserman, Another twist in the march to marriage equality, PRAWFSBLAWG (Feb. 24, 2015), http://prawfsblawg.blogs.com/prawfsblawg/2015/02/ano ther-twist-in-the-march-to-marriage-equality.html.

468. The lawsuit suffered from two additional problems. Unlike in the first action, Judge Davis would have been entitled to judicial immunity from the claims for damages. And the claims for injunctive relief would have failed for lack of an initial declaratory judgment. See Wasserman, supra note 7.

469. Two weeks after Obergefell, Alabama courts began granting adoptions to samesex couples. See Lee Roop, Alabama courts end legal limbo, begin approving same-sex couple adoptions, AL.COM (July 17, 2015, 6:30 AM), http://www.al.com/news/huntsville 
And the lasting lesson of the marriage equality litigation demonstrates that process matters in constitutional litigation.

/index.ssf/2015/07/alabama_courts_end_legal_limbo.html. A July 24, 2015 hearing date was set for the Searcy-McKeand adoption. 